\title{
A critical review on the end uses of recycled water
}

\author{
ZHUO CHEN, HUU HAO NGO and WENSHAN GUO \\ School of Civil and Environmental Engineering, University of Technology Sydney, \\ Broadway, NSW 2007, Australia
}

Recycled water provides a viable opportunity to supplement water supplies as well as alleviate environmental loads. This study examines the sources of recycled water and discusses various end uses. This work focuses on reviewing the historical development and current status of recycled water on a global scale with containing the evolvement of wastewater treatment technologies, water quality guidelines and public attitudes. This review also illustrates typical case studies of recycled water in a number of countries, including Australia, Asia, the U.S., Latin America, Europe, the Middle East and Africa. These pilot studies can be good examples for the future projects. The study identifies the good prospects of further expansion and exploration of current and new end uses while emphasizing the integrated water planning and management as well as challenging and tasks in the future.

KEYWORDS: water recycling and reuse; end use; treatment; water quality; case study

Address correspondence to Huu Hao Ngo, Centre for Technology in Water and Wastewater, School of Civil and Environmental Engineering, University of Technology Sydney, Broadway, NSW 2007, PO Box 123, Broadway, NSW 2007, Australia; Tel: +61 2 9514 2745; Fax: + 6129514 2633; Email: h.ngo@uts.edu.au 
With the social development and population increase, water consumption has increased beyond sustainable levels in many parts of the world (Dolnicar and Schafer, 2009). Uneven distributed water resources, severe droughts, groundwater depletion, water quality deterioration and climate change make the current water supply situation even worse. In many countries, fresh water scarcity is already heavily emerged which is considered as the single most important factor limiting socio-economic growth in the 21 st century (Anderson, 2003a; Asano, 2001). According to International Water Management Institute's (IWMI) report, Australia, California, the Middle East and the Mediterranean have been regarded as high water stress regions (IWMI, 2006a). Likewise, the situation of water pollution and overextraction in Asia and Africa is far from optimistic. Consequently, exploring alternative water resources has become an urgent issue, especially in these severe water shortage areas. Alternative resources include the capture and use of rainwater, stormwater as well as recycled water and desalinated water, among which, recycled water provides a more constant volume of water than rainfall-dependent sources. It also helps in alleviating the pressure on existing water supplies and protecting remaining water bodies from being polluted. Thus, it is increasingly being considered as a supplementary water supply (Huertas et al., 2008). More specifically, recycled water can save freshwater thus lessen mankind's impact on the world's water environment and benefit human beings (Anderson, 2003a). According to United States Environmental Protection Agency's (U.S. EPA) annual report, recycled water reuse accounts for $15 \%$ of total water consumption in the U.S., which is tantamount to save approximately 6.4 Gigalitre per day (GL/d) of fresh water (U.S. EPA, 2004). Moreover, recycled water can introduce some economic benefits to local government or private sectors. 
irrigating with recycled water which contains some amount of nutrients. According to South Australia government, recycled water used to irrigate vineyards at McLaren Vale has already gotten an estimated benefit of \$120 million (DENR, 2010).

On the other hand, recycled water can benefit the ambient environment. Pasqualino et al. (2010) pointed out that replacing potable and desalinated water by recycled water for nonpotable purposes (e.g., irrigation, industry, urban cleaning and fire fighting) could result in lower environmental impacts in terms of acidification potential, global warming potential and eutrophication potential. Besides, environmental loads exerting by effluent discharge can be mitigated to some extent. This strength is fairly distinct as many studies have already demonstrated massive adverse effects on aquatic sensitive ecosystems from wastewater effluent in terms of nutrients pollution, temperature disturbance and salinity increase. Taking South San Francisco Bay as an example, after conducting a \$140 million recycling project in 1997, the natural salt water marsh threatened by high volumes of discharged wastewater was solved. Apart from this, recycled water can also be used to create or enhance wetlands with the advantages of flood diminishment, fisheries breeding, etc. (U.S. EPA, 2004).

The earliest wastewater reuse case on record can date back to 5000 years ago whereas the modern birth of recycled water application was in the mid-19th century together with the prosperity of wastewater treatment technologies (Angelakis, 1996; Okun, 1996). Before 1990s, $70 \%$ of reused wastewater was processed to a secondary treatment level by conventional activated sludge (CAS) method and the effluent was only suitable for agricultural uses in less developed areas. Over the last 10-15 years, with the rapid development and wide acceptance of membrane technologies in wastewater treatment, the recycled water applications have been broadened from non-potable uses (e.g., irrigation, industry, environmental flow, residential use, etc.) to indirect and direct potable reuses (IPR and DPR) in developed countries (Pearce, 2008; Rodriguez et al., 2009). While the technical 
possibility to produce recycled water of virtually any quality has already been achieved, the actual practices of recycled water are still limited due to several constraints (e.g., infrastructure and transport cost, land availability, operability and public objection). In developing countries, the absence of financial and technical resources is the main obstacle in adopting advanced treatment techniques and wastewater reuse is often not well planned, which can potentially cause health and environmental sanitation problems (Asano, 2001; Asano et al., 2007). Fortunately, many countries and areas have already noticed the importance and prospect of the fit-for-purpose recycled water reuses, thus substantial recycled water guidelines and regulations towards specific end uses as well as considerable national or local analysis reports on water quality and risk control have been established. These actions would undoubtedly standardize the treatment level, improve the reliability of water quality and enhance the public acceptance. A detailed review of the recycled water applications in the past, the current status and development as well as the future tendency and new end uses will be presented as follows.

To better determine the specific end uses coupled with corresponding treatment and associated water quality criteria of recycled water, it is important to understand the meanings and related terminologies of recycled water systematically and comprehensively. Meanwhile, each source of recycled water has its own characteristics and constituents that require different treatment level and may have distinct strengths and weaknesses for certain reuse purposes. Thus, it is also indispensable to understand all kinds of recycled water sources and their characteristics for fit-for-purpose studies and cost effectiveness analyses. In some previous literature, water recycling is defined as reclamation of effluent generated by a given 
user for on-site use by the same user, such as industry where the recycling system is a close loop (Asano and Levine, 1996). However, in recent years, there are other more general definitions; for example, the California Water Code defined it as 'water which, as a result of treatment of waste, is suitable for a direct beneficial use or a controlled use that would not otherwise occur' (State of California, 2003). Besides, Asano and Bahri (2011) stated that water reclamation is the treatment or processing of wastewater to make it reusable while water recycling and reuse is using wastewater in a variety of beneficial ways such as agricultural, industrial or residential purposes. In Australia, the term 'water recycling' has been regarded as the preferred term to be adopted for generic water reclamation and reuse. Sources of recycled water are wastewater effluents coming from previous uses, including greywater, blackwater, municipal wastewater or industry effluents. The stream of recycled water may be comprised of any or all of these waters (ATSE, 2004).

\section{Greywater}

Greywater refers to urban wastewater that includes water from household kitchen sinks, dishwashers, showers, baths, hand basins and laundry machines but excludes any input from toilets (ATSE, 2004; Eriksson et al., 2002; Li et al., 2009). Another definition by Al-Jayyousi (2003) excludes the steam from kitchen wastewater. The quality of greywater varies depending upon the size and behaviour of the residents as well as the volume of water and the chemicals used. Generally, it is less polluted and low in contaminating pathogens, nitrogen, suspended solids and turbidity compared with municipal and industrial wastewaters. However, in countries such as Thailand and Israel where phosphorus-containing detergents are not banned, phosphorus concentrations in households can be as high as 45-280 mg/L. In some cases, high Biochemical Oxygen Demand (BOD) and Chemical Oxygen Demand (COD) concentrations might also be observed, which are caused by chemical and 
pharmaceutical pollutants from soaps, detergents and personal care products as well as food wastes in kitchen sinks (Morel et al., 2006). With respect to the treatment methods, physical (e.g., coarse sand and soil filtration and ultrafiltration) and chemical (e.g., coagulation, photocatalytic oxidation, ion exchange and granular activated carbon) treatments are suitable to treat low strength greywater (e.g., laundry and showering wastewaters) for either restricted or unrestricted non-potable uses under safe conditions. These treatment technologies are widely used at small scale residences, which are able to reduce $30-35 \%$ of freshwater consumption. Comparatively, for medium and high strength greywater (e.g., kitchen wastewater), additional biological treatment processes such as Sequencing Batch Reactor (SBC), Constructed Wetlands (CWs) or Membrane Bioreactor (MBR) are often used to remove biodegradable organic substances (Diaper et al., 2001; Li et al., 2009). As the involved treatment technologies are relatively simple, easily conducted and less costly, its reuse is receiving more and more attention in countries including Australia, Japan, North America, UK, Germany and Sweden. For example, the first major in-building greywater recycling scheme was undertaken at Greenwich in UK, where greywater was collected from hand basins and further reused for toilet flushing (ATSE, 2004). Apart from toilet flushing, which is the most common application of greywater, other uses such as garden irrigation, recreational impoundments watering as well as clothes washing are also being practiced (Pidou et al., 2008).

\section{Blackwater}

Blackwater refers to wastewater coming from toilets. Blackwater is highly polluted which contains high concentrations of organic pollutants, nutrients and a large variety of microorganisms (e.g., enteric pathogens). Due to complex treatment processes and strong public 
severe water crisis still paid effort to recycle and reuse black water. For example, in Australia, one trial conducted in South East Queensland in 2009 was to reuse black water in sewered areas (DERM, 2009). Other uses including toilet flushing, agricultural irrigation and outdoor hose tap washing were reported sporadically as well (AWS, 2010). Besides, it is worth noticing that the nutrient recovery rate of some advanced blackwater stream separation devices, especially for nitrogen and phosphorus, can be as high as 85\% (Voorthuizen et al., 2008). These massive nutrients can be sent back to agriculture to replace industrial fertilizers. Sweden and Germany have already practiced on advanced dual flush and vacuum urineseparating toilets with more than 3,000 installations (ATSE, 2004).

\section{Municipal Wastewater}

Municipal wastewater is the largest and most significant resource for water reuse around the world. Prior to 1940s, most municipal wastewater was generated from domestic and commercial sources (Metcalf and Eddy, 1991). After that, miscellaneous industrial wastewaters have been increasingly discharged to municipal collection systems because of industrialization, resulting in variational municipal wastewater quality (Jern, 2006). Presently, as many countries do not have separate sewage collection pipelines, greywater, blackwater, industrial wastewater and other waste streams from hospitals and commercial facilities are all discharged into municipal sewage systems. Hence, municipal wastewater often contains a broad spectrum of contaminants (e.g., organic matters, pathogens, inorganic particles) which can be potential risks to human health and the environment (UN, 2003; Shatanawi et al., 2007). Particularly, some inorganic chemical pollutants (e.g., sodium, potassium, calcium, chloride, bromide and trace heavy metals) are of particular concern in agricultural and landscape irrigation, as highly saline irrigation water can severely degrade the soil and the accumulation of heavy metals in soil can pose threats to the food chain. 
179 Furthermore, when considering the recycled water for IPR and DPR schemes, the trace organic pollutants such as Pharmaceutical Active Compounds (PhACs) and endocrine disrupting compounds (EDCs) are also important parameters which are likely to cause adverse biological effects to health at part per trillion concentrations (Weber et al., 2006). Owing to high hydrophilicity and low adsorption ability, they are poorly removed by CAS. Besides, from microbiological aspects, the main pollution groups in municipal wastewater are excreted organisms and pathogens from human and animal origins, where enteric viruses and protozoan pathogens are significantly more infectious than other bacterial pathogens. To determine the presence of pathogens in recycled water samples, Ecoli, total coliform, Enterococci, Giardia, Campylobacter and Cryptosporidium are commonly used as indicators (Khan and Roser, 2007).

Regarding the municipal wastewater treatment, both UF/RO and MBR processes perform well in treating TSS, COD, BOD and microbial pollutants (Table 1). Sipma et al. (2010) indicated that MBR is superior over CAS in filtering hydrophobic and low biodegradable compounds such as PhACs and EDCs. Besides, membrane filtration has received considerable attentions in countries including Australia, China, Singapore, the U.S., Canada, Europe and the Middle East since it is capable of removing not only suspended solids and organic compounds but also inorganic contaminants such as heavy metals in wastewater through physical means. Depending on the pore size of the semi-permeable membrane, membrane technologies includes Microfiltration (MF), Utrafiltration (UF), Nanofiltration (NF) and Reverse Osmosis (RO). MF membranes have the largest pore size $(0.05-2 \mu \mathrm{m})$ and typically reject suspended particles, colloids, and bacteria. UF $(<0.1 \mu \mathrm{m})$ and NF (2 nm) membranes have smaller pores, which can remove natural organic matter/soluble macromolecules and dissociated acids/pharmaceuticals/sugars/divalent ions, respectively. RO 
membranes $(0.1 \mathrm{~nm})$ are effectively non-porous and retain even many low molar mass solutes as water permeates through the membrane (ATSM, 2010; Sagle and Freeman, 2004).

Industrial Wastewater

Industrial wastewaters are defined as effluents that result from human activities which are associated with raw material processing and manufacturing. The composition of industrial wastewater varies considerably owing to different industrial activities. Even within a single type of industry, specific processes and chemicals used to produce similar products can differ, which leads to significant changes in wastewater characteristics over time. Table 1 illustrates typical wastewater compositions in several industrial categories including the food, paper and tannery industries. Generally, wastewaters from food processing industries (e.g., potato, olive oil and meat processing) are contaminated with high levels of BOD, COD, oil and grease, TSS, nitrogen and phosphorous. Apart from high COD concentrations, industrial processing wastewaters (e.g., chemical and pharmaceutical producing, paper, textile, tannery, and metal working and refinery wastewaters) might be rich in heavy metals (e.g., $\mathrm{Cd}, \mathrm{Cr}, \mathrm{Cu}$, $\mathrm{Ni}, \mathrm{As}, \mathrm{Pb}$ and $\mathrm{Zn}$ ) and other toxic substances. The above mentioned hazards can potentially pose risks to human health and the environment in terms of waterborne diseases, eutrophication and ecosystem deterioration. Besides, heavy metals can cause serious health effects, including reduced growth and development, cancer, organ damage, nervous system damage and even irreversible brain damage (Barakat, 2010; Bielefeldt, 2009; Jern, 2006). To classify these toxic compounds, some toxicity scores or indexes regarding industrial effluents have been developed, which can provide suggestions to wastewater recycling and reuse. Tonkes et al. (1999) developed a four-toxicity-class system which was based on a percentage effect wastewater volume $(\mathrm{w} / \mathrm{v})$ ranking, considering the effect concentration of organism towards the strongest response at 50\% (EC50) value as endpoint $(<1 \% \mathrm{w} / \mathrm{v}=$ very acutely 
toxic; $1-10 \% \mathrm{w} / \mathrm{v}=$ moderately acutely toxic; $10-100 \% \mathrm{w} / \mathrm{v}=$ minor acutely toxic; and $>100 \%=$ not acutely toxic). Similarly, Persoone et al. (2003) and Libralato et al. (2010) established other toxicity classification approaches in wastewater based on various weighting methods. When toxicity is absent, wastewater might be safely reused. Otherwise, when some actions must be undertaken to improve the effluent quality, toxicity outcomes can help to support the implementation of the best available technologies for wastewater treatment (Libralato et al., 2010).

According to Table 1, MBR is proved to be an effective treatment method, especially in removing low biodegradable pharmaceutical compounds whereas CWs can be considered as a relatively low cost option but requires large space for treatment. To treat the heavy metalcontaminated wastewater, Barakat (2010) reported several methods and indicated that new adsorbents and membrane filtration have been the most frequently studied and widely applied in industrial effluent treatment. Specially, the use of biological material (e.g., bacteria, algae, yeasts, fungi or natural agricultural by-products) as biosorbent has received a great deal of interest because of the higher removal efficiency and relatively lower cost compared with conventional methods such as precipitation, ion exchange, etc. (Das et al., 2008; Wang and Chen, 2009). Igwe et al. (2005) demonstrated that the adsorption capacity of maize cope and husk for $\mathrm{Pb}^{2+}, \mathrm{Cd}^{2+}$ and $\mathrm{Zn}^{2+}$ were $456,493.7$ and $495.9 \mathrm{mg} / \mathrm{g}$ respectively. Similarly, bacillus was evaluated by Ahluwalia and Goyal (2006) and could adsorb 467, 85.3, 418, 381 and 39.9 $\mathrm{mg} / \mathrm{g}$ for $\mathrm{Pb}^{2+}, \mathrm{Cd}^{2+}, \mathrm{Zn}^{2+}, \mathrm{Cu}^{2+}$ and $\mathrm{Cr}^{6+}$, respectively. However, Barakat (2010) pointed out that in the near future, the most promising methods would be the photocatalytic ones which consume cheap photons from the UV-near visible region. After going through sufficient barriers, the treated effluent can be reused as cooling water, boiler feed water or industrial process water in closed industrial processing systems. Alternatively, it might be discharged to 
252 centralized municipal treatment plants for external integrated water reuses (Mohsen and 253 Jaber, 2002). 
TABLE 1. The characteristics of major wastewaters and associated treatment methods

\begin{tabular}{|c|c|c|c|c|c|c|c|c|}
\hline Wastewater type & $\begin{array}{l}\text { Average } \\
\text { pH range }\end{array}$ & $\begin{array}{l}\text { Suspended } \\
\text { solids (mg/L) }\end{array}$ & $\begin{array}{l}\mathrm{BOD}_{5} \\
(\mathrm{mg} / \mathrm{L})\end{array}$ & $\begin{array}{l}\mathrm{COD} \\
(\mathrm{mg} / \mathrm{L})\end{array}$ & $\begin{array}{l}\text { TKN } \\
(\mathrm{mg} \mathrm{N} / \mathrm{L})\end{array}$ & $\begin{array}{l}\text { Total P } \\
(\mathrm{mg} / \mathrm{L})\end{array}$ & Salt (g/L) & References \\
\hline \multicolumn{9}{|l|}{ Greywater } \\
\hline Bathroom and hand basin & $6.4-8.1$ & $7-705$ & $50-300$ & $100-633$ & $3.6-19.4$ & $0.1-49$ & - & \multirow{2}{*}{ Li et al., (2009) } \\
\hline Laundry & $7.1-10$ & $68-465$ & $48-472$ & $231-2950$ & $1.1-40.3$ & $>171$ & - & \\
\hline $\begin{array}{l}\text { Treatment process: } \\
\text { Coagulation-Disinfection }\end{array}$ & - & $69 \%$ & $61 \%$ & $58 \%$ & - & - & - & Sostar-Turk et al., (2005) \\
\hline Kitchen & $5.9-7.4$ & $134-1300$ & $536-1460$ & $26-2050$ & $11.4-74$ & $2.9->74$ & - & Li et al., (2009) \\
\hline Treatment process: MBR & - & $99 \%$ & $99 \%$ & $89 \%$ & - & - & - & Winward et al., (2008) \\
\hline \multicolumn{9}{|l|}{ Municipal wastewater } \\
\hline Municipal & $6-8$ & $6-8$ & $110-400$ & $250-1000$ & $20-85$ & $4-15$ & $<0.5$ & Bielefeldt, (2009) \\
\hline $\begin{array}{l}\text { Treatment process: } \\
\text { Secondary-UF-RO }\end{array}$ & - & $100 \%$ & $96 \%$ & $98 \%$ & $80.5 \%$ & $93.5 \%$ & - & Oron et al., (2008) \\
\hline Secondary-Ozonation-MF & - & $60 \%$ & - & $60 \%$ & $32 \%$ & $100 \%$ & - & $\begin{array}{l}\text { Van Houtte and } \\
\text { Verbauwhede, (2008) }\end{array}$ \\
\hline Tertiary-SAT & - & $100 \%$ & $99.8 \%$ & $99 \%$ & $99.9 \%$ & $99.1 \%$ & - & Arlosoroff, (2006) \\
\hline MBR & - & $99 \%$ & $>97 \%$ & $89-98 \%$ & $36-80 \%$ & $62-97 \%$ & - & Melin et al., (2006) \\
\hline \multicolumn{9}{|l|}{ Industrial Wastewater } \\
\hline Brewery & $3.3-7.6$ & $500-3000$ & $1400-2000$ & $815-12500$ & $14-171$ & $16-124$ & - & \multirow{2}{*}{$\begin{array}{l}\text { Wang et al., (2004); } \\
\text { Bielefeldt, (2009) }\end{array}$} \\
\hline Dairy milk-cheese plants & $5.2-11.3$ & $350-1082$ & $709-10000$ & $189-20000$ & $14-450$ & $37-78$ & 0.5 & \\
\hline Treatment process: MBR & - & $98.9 \%$ & $97 \%$ & $88 \%$ & $10 \%$ & - & - & Galil and Levinsky, (2007) \\
\hline Pulp and paper mill & $6.6-10$ & $21-1120$ & $77-1150$ & $100-3500$ & $1-3$ & $1-3$ & 0.05 & Bielefeldt, (2009) \\
\hline Treatment process: MBR & - & $99.1 \%$ & $98 \%$ & $86 \%$ & $90 \%$ & - & - & Galil and Levinsky, (2007) \\
\hline Tannery industry & $8-11$ & $2070-4320$ & $1000-7200$ & $3500-13500$ & $250-1000$ & $4-107$ & $6-40$ & Bielefeldt, (2009) \\
\hline $\begin{array}{l}\text { Treatment process: } \\
\text { CWs (HRT } 7 \text { days) }\end{array}$ & - & $88 \%$ & $77 \%$ & $83 \%$ & $48 \%$ & $38 \%$ & - & Calheiros et al., (2009) \\
\hline
\end{tabular}

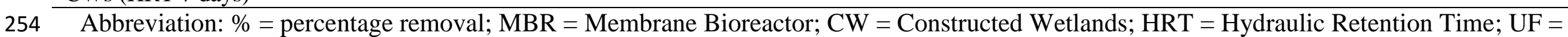

255 Ultrafiltration; RO = Reverse Osmosis; MF = Microfiltration; SAT = Soil Aquifer Treatment 
258 In cities and regions of developed countries, wastewater collection and treatment have been 259 the common practice. The U.S. and Saudi Arabia are highest-ranked countries associated 260 with the total treated wastewater reuse, while Qatar, Israel and Kuwait are the most noteworthy countries considering the per capita water reuse (Jimenez and Asano, 2008). Comparatively, in low-income and many middle-income countries, the irrigation practices often involve the direct use of untreated wastewater. For instance, in Kumasi, Ghana, with a population of 2.5 million in 2010 , up to $70 \%$ of the irrigation water comes from polluted wastewater where the concentration of faecal coliform ranges from 104 to $108 \mathrm{CFU} / 100 \mathrm{ml}$ (Keraita et al., 2003; WSUP, 2010; World Bank, 2010). Although some developing countries have begun to conduct municipal wastewater treatment, the treated effluent still fails to fulfil the reuse requirements in some cases (Asano, 2001). Hence, it can be seen that water reuse situations vary greatly in different countries and the application of recycled water depends heavily on available treatment technologies, economic considerations, current water supply status, environmental conditions, public perceptions and the relative stringency of waste discharge requirements (Asano and Bahri, 2011). According to what degree it might contact with people, the end uses of recycled water can be generally divided into three categories: non-potable uses, indirect potable uses and direct potable uses. Figure 1 illustrates different reuse categories as well as specific end uses, where recycled water plays different roles (Asano et al., 2007; Bitton, 2011; Dolnicar and Schafer, 2009). 


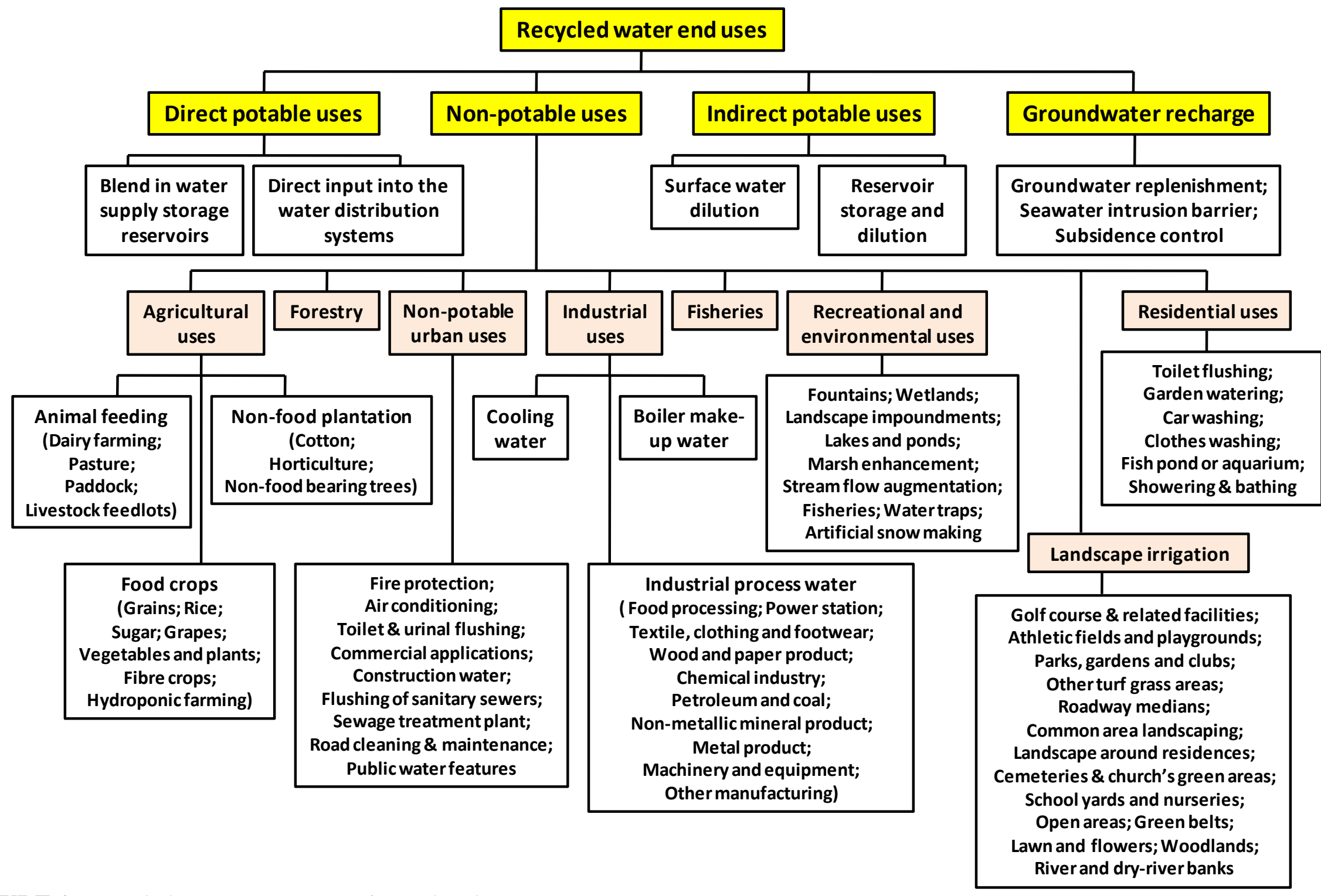

FIGURE 1. Recycled water reuse categories and end uses. 
Wastewater reuse in agricultural irrigation has the longest history that has lasted for 5000 years (Angelakis, 1996). As far back as 3000-1000 BC, wastewater was used back for irrigation in ancient Greece and Minoan civilisation (Asano and Levine, 1996; Kretschmer et al., 2004). In more recent history, some of the earliest recycling projects for irrigation purposes were implemented in the Western U.S. in the late 1920s, together with the publishment of initial water reuse standards in California (Table 2). At that time, most wastewater effluents only suffered from primary or even no pre-treatment before applying to agriculture, triggering health risks and environmental pollution issues potentially. This situation even lasted for 21 st century in some developing countries. Since the mid 1900 s, agricultural uses of recycled water have been continuously developed as many farmers have recognised notable economic benefits on using recycled water which contains higher nutrient contents than fresh water, rainwater and stormwater. Till the 1980s, primary effluents were still allowed for irrigating fodder, fibre and seed crops, while secondary treatment was the minimum criteria for food crops and pastures' irrigation in California and France. Meanwhile, international wastewater quality standards, regulations and guidelines such as WHO 1989 and FAO 1985 were established preliminarily (Table 2). These sets of guidelines were sketchy and controversial but have allowed a real development of wastewater reuse (Bahri, 1999). In the 1990s, water reuse on agriculture had rapid development in France because of the occasional drought conditions and the evolution of intensive irrigated farming in South-western France and the Parris region. Other agricultural schemes were also found around the world. During that period, technical feasibility of achieving tertiary and quaternary level was fulfilled. However, in practice, high quality effluents were seldom 

water quality guidelines were published over time which were undoubtedly have more strict restrictions on detailed water quality parameters than earlier ones (Table 2). Generally, these guidelines regarded secondary and disinfection processes as minimum requirement. 
TABLE 2. Historical wastewater reuse restrictions and guidelines in agriculture

\begin{tabular}{|c|c|c|c|c|}
\hline $\begin{array}{l}\text { Time } \\
\text { period }\end{array}$ & Water quality guideline & Types of irrigation crop & Minimum treatment required & Water quality criteria \\
\hline \multirow{2}{*}{$\begin{array}{l}\text { In the } \\
1920 \mathrm{~s}\end{array}$} & \multirow{2}{*}{$\begin{array}{l}\text { California State Board of } \\
\text { Health, } 1918\end{array}$} & Crops & Settlement & \multirow[b]{2}{*}{-} \\
\hline & & Restricted garden crops & 30 days settlement & \\
\hline \multirow{4}{*}{$\begin{array}{l}\text { In the } \\
1980 \mathrm{~s}\end{array}$} & \multirow{4}{*}{ WHO, 1989} & Very restricted crops & Sedimentation and pre-treatment & Coliform bacteria (per $100 \mathrm{~mL}$ ) $<1000$ \\
\hline & & & & \multirow{3}{*}{ Helminths eggs $<1$} \\
\hline & & Restricted crops & $\begin{array}{l}8-10 \text { days retention in waste } \\
\text { stabilization ponds }\end{array}$ & \\
\hline & & Without restrictions & Series of waste stabilization ponds & \\
\hline \multirow{3}{*}{$\begin{array}{l}\text { In the } \\
1990 \text { s }\end{array}$} & \multirow[t]{2}{*}{ US EPA, 1992} & Food crops eaten raw & $\begin{array}{l}\text { Secondary, filtration and } \\
\text { disinfection }\end{array}$ & $\begin{array}{l}\mathrm{pH}=6-9 \\
\mathrm{BOD}<10 \mathrm{mg} / \mathrm{L} \\
\text { Suspended solids }(\mathrm{SS})<5 \mathrm{mg} / \mathrm{L} \\
\text { Faecal coliform }(\mathrm{FC}) / 100 \mathrm{~mL}-\text { Non- } \\
\text { detectable } \\
\mathrm{Cl}_{2} \text { residual after } 30 \mathrm{~min} \text { retention time } \\
>1 \mathrm{mg} / \mathrm{L}\end{array}$ \\
\hline & & $\begin{array}{l}\text { Restricted access areas and } \\
\text { processed food crops } \\
\text { (Pasture, orchards, vineyards, } \\
\text { etc.) }\end{array}$ & Secondary and disinfection & $\begin{array}{l}\mathrm{pH}=6-9 \\
\mathrm{BOD}<30 \mathrm{mg} / \mathrm{L} \\
\mathrm{SS}<30 \mathrm{mg} / \mathrm{L} \\
\mathrm{FC} / 100 \mathrm{~mL}<200 \\
\mathrm{Cl}_{2} \text { residual after } 30 \text { min retention time } \\
>1 \mathrm{mg} / \mathrm{L}\end{array}$ \\
\hline & Cyprus, 1997 & \multicolumn{2}{|c|}{ Tertiary (filtration and disinfection) } & $\begin{array}{l}\text { BOD }<10 \mathrm{mg} / \mathrm{L} \\
\mathrm{SS}<10 \mathrm{mg} / \mathrm{L} \\
\mathrm{FC} / 100 \mathrm{~mL}<50 \\
\text { Helminths eggs } / 100 \mathrm{~cm}^{3}-\text { Non- } \\
\text { detectable }\end{array}$ \\
\hline
\end{tabular}


Currently, agricultural irrigation still represents the largest use of recycled water throughout the least developed regions (e.g., Middle East, South America and North Africa) while in most developed regions (e.g., Australia, Japan, the U.S. and Europe), the number of urban reuse schemes are as high or much higher than the number of agricultural irrigation schemes (Brissaud, 2010). For example, in Australia, the fraction of recycled water used in agriculture decreased from 66\% to 29\% over the period 2004 and 2009 (Figure 2). So far, there are about 270 different agricultural irrigation schemes across the country, using 106 GL of recycled water per year. As can be seen from Figure 3, the highest consumption of recycled water is the cotton industry followed by the grain and sugar industries. These three types represent almost $47 \%$ of the total agriculture recycled water consumption. Nonetheless, considering the annual total water consumption in agriculture (7300 GL in 2008-09), the contribution of recycled water was small, which only accounted for $2 \%$ (ABS, 2010). The proportion is being improved and correspondingly, Australia has published its national recycling guidelines with generally 4 classes of water quality while most of states also have local guidelines that are slightly different from others. Normally, for raw human food crops and vegetations, Class A treatment comprising of tertiary and disinfection is required, while for processed or cooked crops, pastures and fodders for dairy animals and non food crops, lower effluent quality (secondary treatment at minimum) is permitted. Complying with specific guidelines, several large-scale irrigation schemes have been successful implemented in Australia, including the Hawkesbury Water Recycling Scheme in Sydney (500 ML/yr of treated wastewater plus $200 \mathrm{ML} / \mathrm{yr}$ of treated stormwater), the Virginia Pipeline Scheme in Adelaide (18 GL/yr) and the Eastern Irrigation Scheme in Melbourne (11 GL/yr). Besides, the Shoalhaven Water's Reclaimed Water Management Scheme in New South Wales (4 GL/yr) has converted the region from dry land to dairy farm without introducing extra charge 
and environmental problems. Additionally, the Wider Bay Water recycling scheme in rural Queensland which used recycled water on 400 Ha sugar cane in 2007 has resulted in the highest producing property in the district (ATSE, 2004).
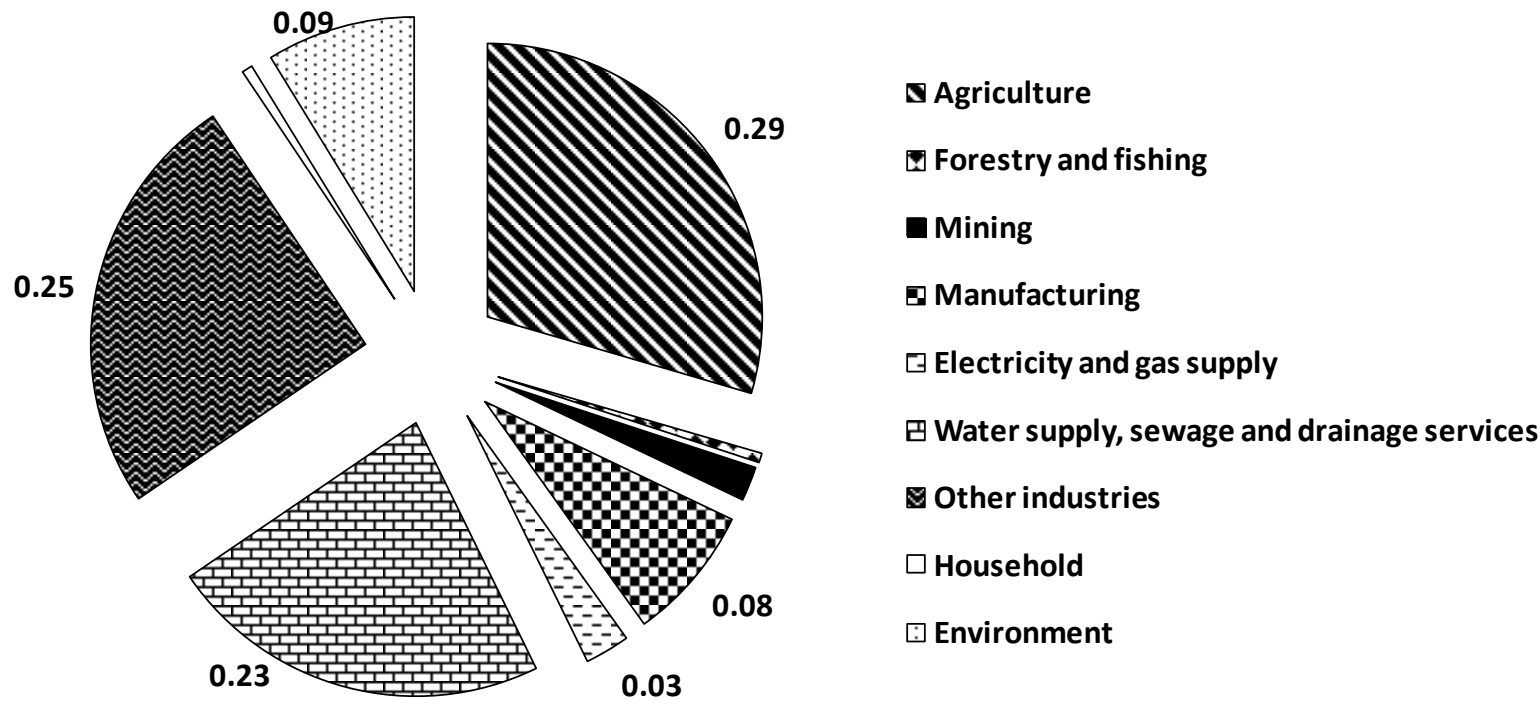

FIGURE 2. The proportion of recycled water use by different categories in Australia in 2008-09. Data adapted from ABS (2010).

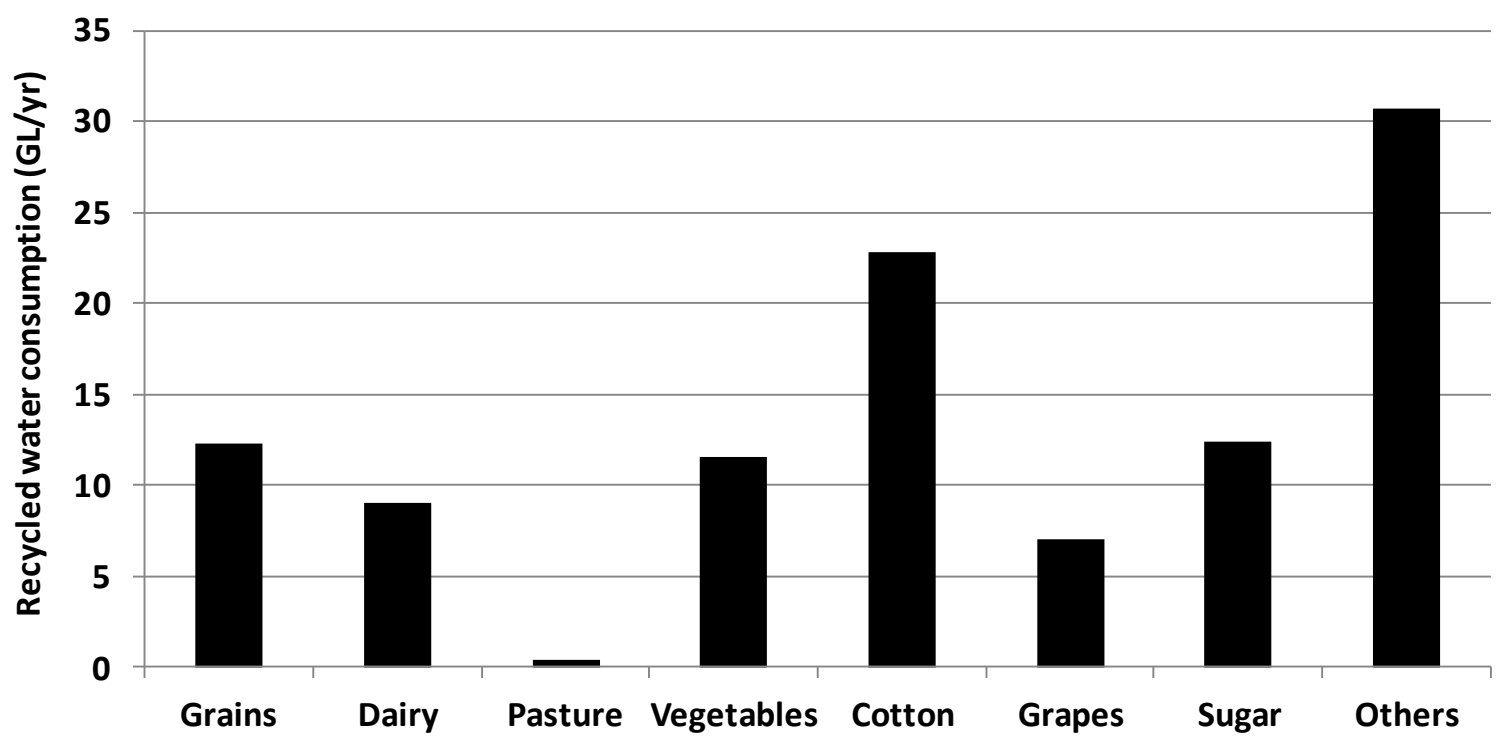

FIGURE 3. Recycled water consumption by different agricultural types in Australia. Data adapted from ABS (2010). 
In Europe, the wastewater reuse projects for agricultural irrigation in France and Italy cover more than 3,000 ha and 4,000 ha of land respectively. The French Clermont-Ferrand recycling scheme, one of the largest projects in Europe, was implemented in 1997, where 10 Megalitre per day (ML/d) of tertiary treated urban wastewater was used for irrigating over 700 ha of maize. Moreover, in Spain, the volume of recycled water use in agriculture has amounted to $780 \mathrm{ML} / \mathrm{d}$ by the year 2002 , accounting for $82 \%$ of the total water reuse (Jimenez and Asano, 2008). Presently, one of the largest schemes in Northern Spain is the wastewater reclamation and reuse project in the City of Vitoria, which supplies $35 \mathrm{ML} / \mathrm{d}$ of recycled water for the 9500-hactare spray irrigation. The initial commitment of the project to produce high quality recycled water (suitable for unrestricted irrigation) has been instrumental in its success and wide acceptance among current and potential users (Asano and Bahri, 2011). Likewise, in Greece, agricultural irrigation is the main interest for reuse where $20 \mathrm{ML} / \mathrm{d}$ of treated wastewater irrigates olive trees, cotton, forest and landscape at regular. Among the total reused water, 3.5 and 0.4 ML/d of treated effluent from Levadia and recycled water for irrigation, especially Israel, Tunisia, Cyprus and Jordan (Angelakis et al., 2003). In Israel, $75 \%$ of recycled water is used for agriculture with irrigation of 19,000 ha (Shanahan, 2010). In Tunisia, about 43 GL/yr of recycled water is allocated for irrigation of fruit trees, fodder, crops and cereals. In Kuwait, agricultural irrigation with recycled water represents $25 \%$ of the total irrigated area. Considering health and environmental issues, the country has established many restrictions. For example, the tertiary treated water is only allowed to irrigate vegetables eaten cooked, industrial crops and forage crops while it is not 
located in Kuwait, Israel and Saudi Arabia, which reuse 375, 310 and 595 ML/d tertiary treated recycled water in agricultural irrigation respectively (Jimenez and Asano, 2008).

Unlike developed countries which are continuously seeking and developing various end uses of recycled water, wastewater in developing countries is predominantly reused in agriculture. In Asian countries such as India and Vietnam, over 73,000 ha and 9,000 ha of land were found to be irrigated by wastewater respectively, whereas in Jordan, almost 100\% of the treated effluent is utilized for irrigation with an area of 13,300 ha either directly at the outlet of the WWTP or after being discharged into reservoirs (Mekala et al., 2008). In Egypt, about 42,000 ha are irrigated with treated wastewater or blended water, where the irrigation area is estimated to reach to 210,000 ha by the year 2020 . However, IWMI has pointed out that about 46 developing countries are using polluted water for irrigation purposes, at least 3.5 million ha were irrigated globally with untreated, partly treated, diluted or treated wastewater until 2006 (IWMI, 2006b; Qadir et al., 2010). In these countries, unplanned and uncontrolled wastewater reuse projects were conducted regardless of health and environmental issues because of limited treatment conditions, socio-economic situations and public recognitions (IWMI, 2010). For example, in Asian countries, this situation is common in Pakistan where nearly $80 \%$ of crop was irrigated by raw sewage, which resulted in enteric diseases and gastrointestinal illnesses. While in Syria, it was reported that in Damascus, some untreated wastewater was discharged to agricultural lands directly, leading to the degradation of surface water and groundwater, especially in the Barada River and Aleppo southern plains. Similarly, the Mezquital Valley, Mexico, also used approximately 3.9-25.9 GL/d of raw wastewater to irrigate over 85,000 ha of crops in the Valley of Mexico and surrounding areas, where the disease spreading was observed as well (Jimenez and Asano, 2008). 


\section{Historical and CurRent Status of WATER Reuse In LANDSCAPE IrRigation}

Using recycled water in landscape irrigation has been practiced around the world for more than 50 years (Stevens et al., 2008). Nevertheless, significant development has occurred in the last 20 years as a result of several reasons, including high water demands, increasing cost of acquiring additional water in urban areas and stringent wastewater discharge requirements (Asano et al., 2007; Lazarova and Bahri, 2004). Currently, landscape irrigation has become the second largest user of recycled water in the world although the particular water demand for different countries and regions varies greatly by geographical location, season, plants and soil properties (Asano, 2001; Asano et al., 2007). In Australia, there are approximately 240 out of total 600 recycled water schemes that are applied to urban environmental irrigation. Many of them have been operating for more than 20 years without negative impact on human health or the environment (Stevens et al., 2008).

In the U.S., it even represents the largest use of recycled water in Florida and the Irvine Ranch Water District in southern California as the state governments recognise that the landscape irrigation schemes are easy to implement, especially wherever potable water is used in urban areas. Figure 4 demonstrates the rapid increase of recycled water consumption in landscape irrigation in Florida (from $44 \%$ in 2003 to 59\% in 2009). In regard to landscape irrigation applications, the end uses listed in Figure 1 can be further categorized into unrestricted access areas and limited or restricted access areas (Tables 3), in which different water reuse quality guidelines will be implemented (Asano et al., 2007; ATSE, 2004; Lazarova and Bahri, 2004). As can be seen in Table 4, the control of important parameters on each guideline over the unrestricted access areas is so critical that tertiary treatment including filtration and disinfection is normally required as these places are mostly located in urban areas and have frequent contact with people. Generally, as unrestricted access areas are 
widely distributed everywhere, there are more reuse schemes (e.g., parks, golf courses,

418

419

420

421

422

423

TABLE 3. Landscape irrigation categories
Limited or restricted access areas

\section{Cemeteries}

Highway medians and shoulders

fields

Public and commercial facilities

Individual and multifamily residences

Golf courses associated with residential properties
Landscaping within industrial areas

Green belts

Golf courses not associated with a residential community

Adapted from Asano et al. (2007). 
TABLE 4. Water reuse guidelines and regulations on Landscape irrigation around the world

\begin{tabular}{|c|c|c|c|c|c|c|}
\hline \multirow{2}{*}{$\begin{array}{l}\text { Water reuse } \\
\text { guidelines } \\
\text { Landscape } \\
\text { irrigation } \\
\text { categories }\end{array}$} & \multicolumn{2}{|l|}{ Victoria, Australia } & \multicolumn{2}{|c|}{ Tasmania (TAS), Australia } & \multicolumn{2}{|l|}{ California, the U.S. } \\
\hline & Water quality criteria & $\begin{array}{l}\text { Treatment } \\
\text { required }\end{array}$ & $\begin{array}{l}\text { Water quality } \\
\text { criteria }\end{array}$ & $\begin{array}{l}\text { Treatment } \\
\text { required }\end{array}$ & Water quality criteria & $\begin{array}{l}\text { Treatment } \\
\text { required }\end{array}$ \\
\hline $\begin{array}{l}\text { Unrestricted } \\
\text { access areas }\end{array}$ & $\begin{array}{l}\mathrm{pH}=6-9 \\
\mathrm{BOD}<10 \mathrm{mg} / \mathrm{L} \\
\mathrm{SS}<5 \mathrm{mg} / \mathrm{L} \\
\text { Ecoli/100 mL }<10 \\
\text { Turbidity }<2 \text { NTU ( } 24 \\
\text { hr median), Turbidity } \\
<5 \text { NTU (max) }\end{array}$ & $\begin{array}{l}\text { Class A recycled } \\
\text { water; } \\
\text { Tertiary treatment } \\
\text { and pathogen } \\
\text { reduction; } \\
\mathrm{Cl}_{2} \text { residual after } \\
30 \text { min }>1 \mathrm{mg} / \mathrm{L}\end{array}$ & $\begin{array}{l}\mathrm{pH}=5.5-8 \\
\text { BOD }<10 \mathrm{mg} / \mathrm{L} \\
\text { Median thermal } \\
\text { tolerant } \\
\text { coliforms } / 100 \mathrm{~mL} \\
<10\end{array}$ & $\begin{array}{l}\text { Class A recycled } \\
\text { water; } \\
\text { Tertiary } \\
\text { treatment and } \\
\text { chlorination }\end{array}$ & $\begin{array}{l}\text { Total Coliforms } \\
\text { (TC)/100 mL <2.2 } \\
\text { Turbidity <2 NTU } \\
\text { ( } 24 \text { hr median), } \\
\text { Turbidity <5 NTU } \\
\text { (95\% over } 24 \text { hr), } \\
\text { Turbidity < } 10 \mathrm{NTU} \\
\text { (any time) }\end{array}$ & $\begin{array}{l}\text { Tertiary } \\
\text { treatment and } \\
\text { chlorination; } \\
\mathrm{Cl}_{2} \text { residual }>5 \\
\mathrm{mg} / \mathrm{L} ; \\
\mathrm{Cl}_{2}>450 \mathrm{mg}- \\
\mathrm{min} / \mathrm{L} \text { contact } \\
\text { time }\end{array}$ \\
\hline $\begin{array}{l}\text { Restricted } \\
\text { access areas }\end{array}$ & $\begin{array}{l}\mathrm{pH}=6-9 \\
\mathrm{BOD}<20 \mathrm{mg} / \mathrm{L} \\
\mathrm{SS}<30 \mathrm{mg} / \mathrm{L} \\
\text { Ecoli } / 100 \mathrm{~mL}<1000\end{array}$ & $\begin{array}{l}\text { Class C recycled } \\
\text { water; } \\
\text { Secondary } \\
\text { treatment and } \\
\text { pathogen } \\
\text { reduction }\end{array}$ & $\begin{array}{l}\mathrm{pH}=5.5-8 \\
\mathrm{BOD}<50 \mathrm{mg} / \mathrm{L} \\
\text { Median thermal } \\
\text { tolerant } \\
\text { coliforms } / 100 \mathrm{~mL} \\
<1000\end{array}$ & $\begin{array}{l}\text { Class B recycled } \\
\text { water; } \\
\text { Secondary } \\
\text { treatment and } \\
\text { disinfection }\end{array}$ & $\begin{array}{l}\mathrm{TC} / 100 \mathrm{~mL}<23 \\
(7 \text { days) } \\
\mathrm{TC} / 100 \mathrm{~mL}<240 \\
\text { org } / 100 \mathrm{~mL} \\
\text { (in any } 30 \text { days) }\end{array}$ & - \\
\hline $\begin{array}{l}\text { Other } \\
\text { guidelines }\end{array}$ & \multicolumn{2}{|l|}{ Japan } & \multicolumn{2}{|l|}{ Germany } & \multicolumn{2}{|l|}{ Spain } \\
\hline $\begin{array}{l}\text { Unrestricted } \\
\text { access areas }\end{array}$ & \multicolumn{2}{|c|}{$\begin{array}{l}\mathrm{FC} / 100 \mathrm{~mL}-\text { Non-detectable } \\
\mathrm{Cl}_{2} \text { residual }>0.4 \mathrm{mg} / \mathrm{L}\end{array}$} & \multicolumn{2}{|c|}{$\begin{array}{l}\text { FC/100 mL }<100 \\
\text { TC/100 mL }<500 \\
\text { BOD }<20 \mathrm{mg} / \mathrm{L} \\
\text { Turbidity }<1-2 \mathrm{NTU} \\
\text { Total Suspended Solids (TSS) }<30 \\
\mathrm{mg} / \mathrm{L} \\
\text { Oxygen saturation }=80-120 \%\end{array}$} & \multicolumn{2}{|c|}{$\begin{array}{l}\text { Ecoli/100 mL - Non-detectable } \\
\text { Turbidity }<2 \mathrm{NTU} \\
\text { TSS }<10 \mathrm{mg} / \mathrm{L} \\
\text { Helminth Egg/10 L }<1\end{array}$} \\
\hline
\end{tabular}


Golf Course Uses. Nearly half of landscape irrigation schemes are related to golf courses. For instance, in Australia, the Dunheved Golf Club which is located in St Marys, 50 $\mathrm{km}$ west of Sydney, has been a typical case, where up to $1 \mathrm{ML} / \mathrm{d}$ of tertiary treated and disinfected effluent was supplied from the St Mary's STP with a contract of over 20 years.

The scheme started in June 2000 and has proved of great value during the severe drought of 2002-03. Another successful scheme in Australia has been conducted in Darwin Golf Course, Tasmania, where 450 ML/year effluent provided by Darwin Golf Course STP has well connected with the golf course irrigation. Furthermore, part of effluent sent to golf course pond can be further utilised in sport field such as Marrara Sports Complex, thereby great water saving can be achieved (ATSE, 2004). In the U.S., the average annual water consumption in golf course is 190-230 ML in the East Coast and 300-380 ML in the southwest. Due to the high water demand, some of the sates have even mandated the use of recycled water for golf courses. Figure 5 shows that golf course irrigation contributed to $36 \%$ and $50 \%$ of the total water reuse in landscape irrigation in Florida and California respectively (Asano et al., 2007).

Florida

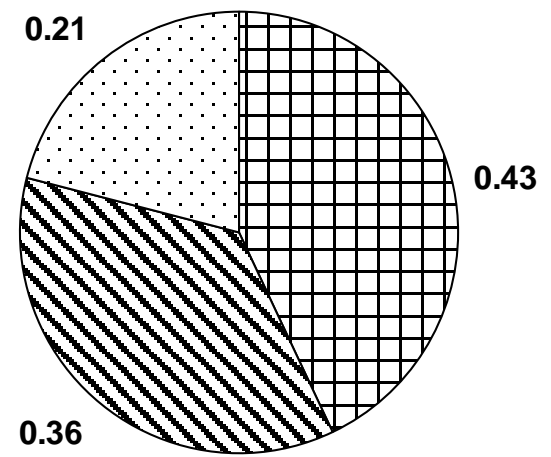

$\square$ Residential $\Delta$ Golf course $\square$ Mixed, other or unkown
California

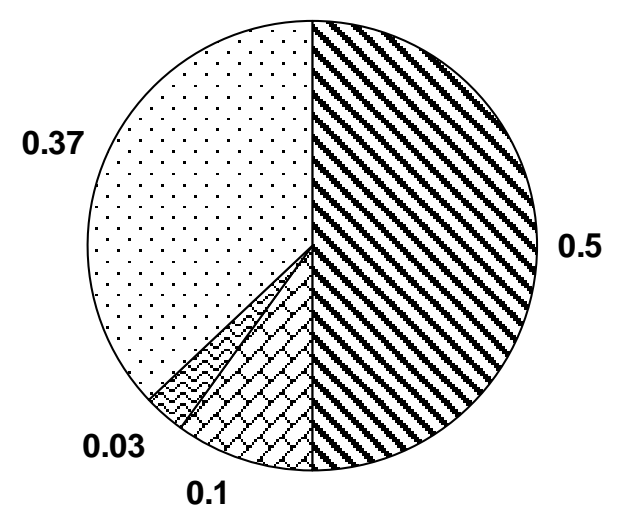

sGolf course $\square$ Public parks, schools and playgrounds Q $\mathrm{G}$ Freeway median $\square$ Mixed, other or unkown 
FIGURE 5. Recycled water use in landscape irrigation. Modified from Asano et al., (2007).

446

447

448

449

450

451

452

453

454

455

456

457

458

459

460

461

462

463

464

465

466

467

468

469

In the city of North Las Vegas, a $113 \mathrm{ML} / \mathrm{d}$ reuse plant with MBR system was commissioned in May 2011 and treats wastewater for golf course irrigation. Apart from this initial reuse option, the city is also considering a plan to provide recycled water for commercial laundries in hotels and concrete mixing plants where recycled water can be used as cooling water in natural gas co-generation facilities as well as dust control water on construction sites (McCann, 2010). When it comes to the Europe, Spain is a representative country as 4 golf courses in Costa Brava, the northeast Spain, have used recycled water as the sole source for irrigation since 2004 (Sala and Millet, 2004). The 2010 scenario of the Spanish National Water Plan has even specified the compulsory use of recycled water for golf course irrigation in many water basins (Candela et al., 2007). Furthermore, the largest project of its kind in the world is the Jumeirah Golf Estates (220 ML/d) in Dubai, United Arab Emirates, the Middle East, which equips an advanced wastewater collection, treatment and tertiary effluent reuse system. Meanwhile, it is also the largest private wastewater financing to date. In Tunisia, using recycled water in golf course even becomes an important component of the tourism development, where at least 8 golf courses are irrigated with secondary treated effluent (Bahri and Brissaud, 1996; GWA, 2008).

Public parks, schools and playgrounds use. Irrigating public areas with recycled water is also widely conducted. However, concerns have been raised owing to the high potential risk of accidental recycled water ingestion, especially when children fall to or touch the grass and then have hand-to-mouth contact. Thus, some cities such as Redwood, California, decided not to use recycled water in school yard and playground irrigation (Asano et al., 2007). Nevertheless, these concerns can be solved by applying appropriate risk control approaches. 

Territory, Australia, was able to minimize the risk exposure of recycled water to people by adopting limiting daytime watering hours and locking the entrance gate when irrigating (ATSE, 2004).

With respect to Asia, China has been actively involving in water reuse trials on landscape irrigations. For example, the Qinghe Water Reclamation Plant in Beijing has successfully provided UF treated effluent for the 2008 Beijing Olympic Games. Among the total capacity of $80 \mathrm{ML} / \mathrm{d}, 60 \mathrm{ML} / \mathrm{d}$ has been used as water supply for landscaping the Olympic Forest Park, and the remaining $20 \mathrm{ML} / \mathrm{d}$ has been used for road washing, toilet flushing and other purposes. The second phase of the plant with the daily average capacity of $320 \mathrm{ML} / \mathrm{d}$ and peak capacity of $450 \mathrm{ML} / \mathrm{d}$ has been commissioned by the end of 2010, which has become China's single largest water reuse scheme. It also plays an important part in the Beijing Government's overall strategy which is to reuse all wastewater produced in the city (GreenTech, 2005; UNEP, 2008). Besides, the Chongqing University, located in southwest of China has conducted a Chongqing greywater demonstration project at the new Huxi campus in 2005. The greywater from a 21 high rise teaching building is collected and treated onsite by constructed wetlands. The treated effluent is blended with rainwater and used for landscape irrigation and scenic lake replenishment. This project is capable of reducing the annual potable water consumption by $150 \mathrm{ML}$. It was estimated that if this project could be replicated at another 9 sites in Chinese cities, approximately $2.5 \%$ of the total water demand in China would be saved in the future (SUW, 2008). Moreover, in the Middle East, to ensure health and environmental safety, the city of Abu Dhabi has treated tertiary recycled water (200 ML/d) with supplement sand filtration and chlorine disinfection before irrigation, which has allowed the city to be a garden city despite high temperature and low rainfall (Jimenez and Asano, 2008). 
Residential landscape uses. Residential landscape irrigation schemes mainly use the recycled water that comes from municipal wastewater and greywater sources and are sometimes coupled with other residential end uses such as toilet flushing and clothes washing. When the water is delivered from area-wide centralized distribution systems, care must be taken to prevent the cross connections of dual or third pipelines. Generally, the recycled water quality is complied with guideline values for unrestricted areas (Table 4) (Asano et al., 2007). In Australia, the Ipswich Water's Carole Park STP, Brisbane, supplied homes. This water was used for irrigating residential areas including road verges, grass areas and median strips as well as Bob Gibbs Park (ATSE, 2004). Besides, the U.S. has another pilot study in California named El Dorado Hills residential irrigation project. From 2005, the

El Dorado Hills WWTP to irrigate all front yards of 6100 residences by dual pipe systems. Meanwhile, more than 60 million American people are using decentralised recycling systems which operated on-site individually for their front yard and back yard irrigation (Asano et al., 2007). In general, owing to broad public acceptance and less stringent water quality requirement compared with potable uses, water reuse in landscape irrigation will be developed significantly in the future.

Industrial Uses

\section{Historical AND CURRENT WASTEATER REUSE In INDUSTRY}

517 Recycled water has been successfully applied to industry in Japan, the U.S., Canada and 518 Germany since the Second World War for more than 70 years. Recently, industrial use is the third biggest contributor to recycled water consumption. In Australia, because of the severe 
drought conditions and mandatory water restrictions, industrial recycling schemes have been expanded to about 80 together with the acceleration of the reuse rate by $25 \%$ in most industrial sectors (Stevens et al., 2008). In Asia, Japan is one of the world's leading countries in this kind. In 1951, sand filtered secondary effluent from Mikawashima WWTP in Tokyo was experimentally used for paper manufacturing in a paper mill nearby, which marked the beginning of wastewater reuse in Tokyo. This pilot study was very successful and the recycled water had begun to be applied in other factories scattered in Mikawashima region (Maeda et al., 1996). In the 1960s, the severe droughts were the driven force of water recycling for industry in Tokyo and Nagoya, while in the 1970s, the quick development of large-scale industrial water recycling schemes was due to the recognition of water conservation and environmental pollution (Suzuki et al., 2002). Since that time, Japan had achieved a 76.3\% water recovery rate within industrial sectors by 1992 (Schmidt, 2008).

Comparatively, the U.S. has the longest history of water reuse in industry. During the 1940s, the prologue of industrial application has been unfolding gradually in the U.S. with the start of using chlorinated wastewater effluent for steel processing (Asano and Levine, 1996). In 1985, a successful industrial water conservation and reuse programme was conducted in 15 companies comprising of electronics manufacturing, metal finishing, paper producing and food processing industries in San Jose, California, which reused 30-40\% industrial water and saved more than 3.7 GL/yr of freshwater (Beekman, 1998). Table 5 gives the treatment criteria associated with industrial uses in the 1990s. Generally, secondary level was regarded as the minimum treatment requirement. During that time, the concept of zero discharge which means total reuse without any wastewater being released into the environment was also put forward in the U.S. and Germany. Besides, industrial use occupied $33 \%$ and $55 \%$ of the total recycled water in northern Europe and Sweden, respectively (Bixio et al., 2006). The major industrial categories associated with substantial water consumption 
include cooling water, boiler feed water and industrial process water (Chiou et al., 2007; U.S. EPA, 2004).

TABLE 5. Historical wastewater reuse restrictions and guidelines in industry

\begin{tabular}{|c|c|c|c|}
\hline Water quality guideline & \multicolumn{2}{|c|}{ Minimum treatment required } & Water quality criteria \\
\hline US. EPA 1992 & \multicolumn{2}{|c|}{ Secondary and disinfection } & $\begin{array}{l}\mathrm{pH}=6-9 \\
\mathrm{BOD}<30 \mathrm{mg} / \mathrm{L} \\
\mathrm{SS}<30 \mathrm{mg} / \mathrm{L} \\
\mathrm{FC} / 100 \mathrm{~mL}<200 \\
\mathrm{Cl}_{2} \text { residual after } 30 \mathrm{~min} \\
\text { retention time }>1 \mathrm{mg} / \mathrm{L}\end{array}$ \\
\hline \multirow[b]{2}{*}{ California 1994} & $\begin{array}{l}\text { Cooling } \\
\text { water }\end{array}$ & $\begin{array}{l}\text { Secondary and } \\
\text { disinfection }\end{array}$ & $\mathrm{TC} / 100 \mathrm{~mL}<2.2$ \\
\hline & $\begin{array}{l}\text { Process } \\
\text { water }\end{array}$ & $\begin{array}{l}\text { Secondary, coagulation, } \\
\text { clarification, filtration } \\
\text { and disinfection }\end{array}$ & $\mathrm{TC} / 100 \mathrm{~mL}<2.2$ \\
\hline Florida 1995 & \multicolumn{2}{|c|}{ Secondary and disinfection } & $\begin{array}{l}\text { BOD }<20 \mathrm{mg} / \mathrm{L} \\
\mathrm{TSS}<20 \mathrm{mg} / \mathrm{L} \\
\mathrm{FC} / 100 \mathrm{~mL}<200\end{array}$ \\
\hline
\end{tabular}

Modified from Crook and Surampalli (1996).

COOLING WATER

550 Cooling water creates the single largest industrial demand of water (more than 50\%) and

551 becomes one of the predominant areas for water saving and reuse in industry (Asano, 2001).

552 Equipments or processes in refineries, steel mills, petrochemical manufacturing plants,

553 electric power stations, wood and paper mills and food processing all require efficient 554 temperature control to make sure the safe and efficient production. In electric power 555 generation plants, cooling water accounts for nearly $100 \%$ of water use. While in other 556 industries, the proportion can range from $10 \%$ in textile mills to $95 \%$ in beet-sugar refineries.

557 Generally, in the U.S., more than $90 \%$ of water consumed by industries results from cooling 558 purposes in comparison with $70 \%$ in Japan (Schmidt, 2008). Cooling systems are either non559 evaporative or evaporative. Once-through cooling water system is a non-evaporative one which involves a simple one-way pass of cooling water through heat exchanger. This system 
561 is simple, flexible and low-cost, where disinfected secondary effluent can be applied.

562 However, it discharged lots of water each time, triggering environmental problems to water

563 bodies (Chiou et al., 2007). Hence, it has been replaced by recirculating evaporative system

564 contemporarily which uses water to absorb process heat and transfer the heat by evaporation

565 either in cooling tower or spray ponds. As the evaporative systems are recirculating

566 continuously, the recycled water is mainly used as makeup water to recover the evaporation

567 loss. Nevertheless, water quality problems (e.g., corrosion, biological growth, scaling, fouling

568 and salinity build-up) in the cooling system often occur unless high grade treatment has been

569 achieved (Schmidt, 2008; U.S. EPA, 2004). In this case, stringent water quality requirements

570 have been specified and additional processes (e.g., coagulation, precipitation and ion

571 exchange) to removal total dissolved solids (TDS) are required (Chiou et al., 2007). Despite

572 of these conditions, recycled water in cooling systems receives large benefits in terms of

573 thermal pollution and water conservation. With the prosperity of treatment technologies,

574 operational costs are reducing gradually and more and more reuse schemes are reported

575 around the world.

576 For example, in Australia, $1 \mathrm{GL} / \mathrm{yr}$ of recycled water, processed through tertiary and 577 nitrification treatment in Wetalla STP, Toowoomba, was supplied to the Millmerran 578 powerhouse for cooling purposes through an $80 \mathrm{~km}$ pipe (ATSE, 2004; VU, 2008). In Asia,

579 Wang et al. (2006) conducted a pilot study at the North China Pharmacy Limited Company 580 and indicated that the product water from both sand filtration/MF/RO and sand 581 filtration/UF/RO systems could fulfil the cooling water quality requirements. Accordingly, 582 the company used $400 \mathrm{ML} / \mathrm{d}$ of treated effluent from the Gaobeidian WWTP as industrial 583 cooling water (Jiang, 2004). Likewise, approximately 10 and 24 ML/d recycled water from 584 Beijiao WWTP and Taiyuan Chemical Plant respectively in Taiyuan has been used for 585 cooling purposes since 1992 (Jimenez and Asano, 2008). You et al. (2001) also studied the 
water reuse in a semiconductor factory in Taiwan, where the RO devices generated ultra pure deionized water from tap water in order to rinse the integrated circuit crystal chips and the RO reject (230 kilolitre per day) was reused as cooling water. They indicated that the pretreatment of the reject water was uneconomical. Increasing the cycles of concentration and reducing the quantity of make-up in the cooling water system would be preferable in the plant. Additionally, the thermal power generation plants of MahaGenco Company at Koradi and Khaparkheda, India, reuse $110 \mathrm{ML} / \mathrm{d}$ of treated water for cooling purposes predominantly. This has become India's largest water reuse project and the company is going to use treated water constantly for the next 30 years, which will directly benefits 1 million people due to significant amount of freshwater savings (USAID, 2009). Nevertheless, a clear water quality standard should be specified later as there are still no guidelines associated with recycled water reuse in industry in India (Jamwal and Mittal, 2010).

In the U.S., about $250 \mathrm{ML} / \mathrm{d}$ of recycled water was supplied from City Phoenix to the Palo Verde Power Station in Sonoran Desert as cooling system makeup water via a 55km pipeline (Anderson, 2003a). Wilcut and Rios (2006) also reported that $118 \mathrm{ML} / \mathrm{d}$ recycled water was able to run cooling towers at four cycles of concentration at many businesses in San Antonio, Texas through the treatment process of acid feed, RO and conventional water softening. There are also numerous petroleum refineries and power stations in the Los Angeles and other regions in California that have successfully used $100 \%$ of recycled water as makeup water for their cooling systems since 1998. However, the water reuse guidelines for makeup water are more stringent in some places which stipulate the ranges of important parameters such as TDS, total alkalinity, phosphate and calcium (U.S. EPA, 2004). The reuse criteria in Greece even restrict the amount of faecal coliform and Legionella for industrial cooling (Brissaud, 2008). Besides, public objection towards recycled water in industrial 
610 cooling was as low as 3\%, compared with $16 \%$ in agriculture and 53\% in drinking (Dolnicar and Saunders, 2006).

612

\section{BOILER FEED WATER}

614 Boiler feed water plays a very important role for the operation of steam generators in many 615 industrial types such as petrochemical plants and power stations. The recycled water used as boiler makeup water should be of very high quality, especially when the boiler is operated under high pressure as wastewater containing impurities may lead to boiler corrosion, deposits and sludge formation, scaling, fouling and foaming. Therefore, the advanced treatment processes such as UF, RO or ion exchange are often required. Mann and Liu (1999) listed the feed water quality requirements for low, medium and high pressure boilers. Some international or local guidelines also specified associated requirements. Recycled water schemes regarding boiler feed water has been successfully conducted in Australia with no reported problems as guidelines stipulate $\mathrm{MF} / \mathrm{RO}$ plus demineralization as necessary treatment (VU, 2008). In Brisbane, Australia, 10.6 to $14 \mathrm{ML} / \mathrm{d}$ of recycled water from MF/RO membranes in the Luggage Point STP was supplied to the refinery of BP Amoco Company as boiler feedwater (ATSE, 2004). Similarly, recycled water from the Dora Creek STP in New South Wales, treated by MF/RO and demineralisation, was sent to the Eraring Power Station at Lake Macquarie as boiler feed water. This has replaced 1.2 GL/yr of potable water which was previously used in the power station to provide steam for driving turbines (Anderson, 2003a).

In Asia, the Gaojing Power Plant in Beijing, China, adopts UF/RO membranes to treat the blow-down from its cooling towers and reuses the treated effluent as boiler feed water. The integrated UF/RO treatment system is able to overcome the problems associated with 634 high hardness, alkalinity, silicon dioxide and sulphate which are typically found in cooling 
water blow-down and around 70\% of water in cooling tower has been reused since 2003 (DCC, 2009). Additionally, the Dagang Oilfield Reclaimed Water Plant in Tianjin, China, commissioned in 2009, uses a submerged MBR (30 ML/d) to treat a 50/50 combination of oil industrial wastewater and local municipal secondary effluent. The treated effluent is sent to nearby power plant, polypropylene plant and coke calcination plant for cooling and boiler feed water supply purposes (Mo and Chen, 2009; Zheng, 2010). In the U.S., as several refineries in California have also used recycled water as primary source of boiler water since 2000, the Californian West Basin Municipal Water District guidelines on recycled water prescribed that pure RO is necessary for low pressure boiler feed in refineries while ultrapure RO is essential for high pressure boiler feed in refineries (U.S. EPA, 2004).

Furthermore, in the Middle East, the world's largest produced water reuse project is the Mukhaizna Water Treatment Facility $(47.7 \mathrm{ML} / \mathrm{d})$ in Oman which has been operated since late 2008. The plant uses 7 mechanical vapour compression (MVC) brine concentrator trains to treat produced water from oil and gas extraction and then reuses high purity distillate as boiler feed water for steam generation. This project has attracted widely public attention from 2009 because of its scale as well as the first adoption of novel and integrated MVC treatment technology in water reuse sector in the Middle East. Currently, the water reuse rate is as high as $90 \%$ and the plant is planning a zero liquid discharge configuration at a later stage (GWA, 2009). More recently, a remarkable project at an oil recovery plant in the partitioned neutral zone between Saudi Arabia and Kuwait has become the first successful large-scale produced boiler water system for steam generation in an enhanced oil recovery application in the Middle East. The plant has de-oiling and de-gasification pre-treatment facilities and recycles untreated oily sour produced water originating from a carbonate oil reservoir, producing up to 
an energy saving plant which only uses $5 \%$ of the energy normally required for single-effect steam evaporation (GWA, 2010).

\section{INDUSTRIAL PROCESS WATER}

In industry, lots of processes (e.g., dust, pollution and fire control and suppression, acid and alkali dilution, plant and equipment rinse, raw material and product washing, friction reduction and lubrication, etc.) involve using substantial amounts of water (Huertas et al., 2008; VU, 2008). The required recycled water quality depends on particular end uses. Generally, low quality water is acceptable for tanning industry; medium quality water is suitable for pulp and paper, textile and metallurgical industries while only high quality water can be adopted in electronics, food processing, chemical and pharmaceutical industries (U.S. EPA, 2004). Wastewater reuse in textile, paper and metallurgical industries have been studied for several years thus many recycling schemes have been successfully conducted and much higher water recycling and reuse rates have been reported.

Pulp and paper mill industry. The pulp and paper making industry is highly water intensive, which ranked third in the world after primary metals and chemical industries (Asghar et al., 2008). In terms of paper quality, the water introduced in the paper machine must meet high quality requirements as the wires must be kept clean to achieve an optimum paper sheet and drainage. At the same time, the efficiency of chemicals may also be affected by the quality of preparation water (Ordonez et al., 2011). However, reusing the effluent within the pulp and paper mills may increase the concentration of organic and inorganic pollutants, which in turn can affect paper formation, increase bacterial loading or cause corrosion and odour (Asghar et al., 2008). Therefore, to achieve high recycling rate, advanced treatment technologies should be exerted. Nowadays, the general water quality requirements 
have already set tertiary treatment with colour removal as minimum level (U.S. EPA, 2004; VU, 2008).

In Asia, the Anand Tissues Ltd., located in Fitkari, Uttar Pradesh, India, produces unbleached kraft paper and adsorbent paper and uses recycled water in paper producing sectors. About $20 \%$ of the final effluent from activated sludge treatment is recycled to the pulp digester while wastewater generated from the pulp mill and the paper machine is reused for pulp washing. The company also recycles water discharged from the paper machine, pulp washing stream and the retentate from raw water RO plant (Tewari et al., 2009). In the U.S., water reuse in paper industry started in the 1950s, during which, freshwater consumption has been reduced by $23 \%$, from approximately $568 \mathrm{ML}$ per ton at the beginning to $133 \mathrm{ML}$ per ton. Between 1955 and 1972, water consumption has been further reduced to 102 ML per ton. Currently, many modern mills have already achieved $100 \%$ recycling rate, using only $61 \mathrm{ML}$ or less of freshwater per ton (U.S. EPA, 2004). For instance, the Mckinley Paper Mill, located in New Mexico, uses a MF/RO system to recycle all the effluent within the mill. The mill mainly produces linerboard and only consumes $1.2 \mathrm{ML}$ of produced water per ton for evaporation during paperboard drying (Ordonez et al., 2011).

There are also several pilot studies conducted in Europe. Ordonez et al. (2011) studied the different recycled water treatment systems in HOLMEN Paper Madrid (HPM) in Spain. The results indicated that both the MF/RO/UV and UF/RO/UV systems achieve constant permeate quality with the percentages of salt rejection above $99 \%$, the number of microorganisms below $1 \mathrm{CFU} / 100 \mathrm{~mL}$ and final COD concentrations below $5 \mathrm{mg} / \mathrm{L}$. Hence, the recycled water is capable of substituting the freshwater in HPM and the company will be the first mill producing $100 \%$ recycled paper using $100 \%$ recycled water. Manttari et al. (2006) conducted a study at Stora Enso Kotka mill in Finland and showed that the pulp and paper mill effluents treated by activated sludge processes could only be reused for production 
of packaging paper. They also found that when the monovalent ion content was low, recycled water by biological pre-treatment plus NF was suitable to be used in the manufacturing processes of paper machine while in high strength wastewater, low-pressure RO membranes were required to remove monovalent anions and dissolved inorganic carbon. Moreover, Koyuncu et al. (1999) used a UF/RO system to treat pulp and paper mill effluents in Turkey. The overall removal efficiencies of $\mathrm{COD}$, colour, conductivity, $\mathrm{NH}_{3}-\mathrm{N}$ were found to be 90 $95 \%, 95-97 \%, 85-90 \%$ and $80-90 \%$ respectively together with $85-90 \%$ recovery rates after integrated membranes. As the effluent was of very high quality, it could be reused as process water internally. Furthermore, the Mondi Paper Company in Durban, South Africa, uses 47.5 ML/d of recycled water from the Durban Water Recycling Plant, suffering tertiary, ozonation and activated carbon treatment. As a result, great water savings in Mondi have been achieved and the water tariff has been reduced by 44\% (Holtzhausen, 2002; VU, 2008).

\section{Metallurgical industry. Metallurgical industry is the largest water consumption sector} among all industrial types in some countries where sinter plant, blast furnace, cold rolling and other processes have great potential to recycle $80-90 \%$ of wastewater (Johnson, 2003). Generally, secondary or tertiary treated recycled water may be suitable for most applications in this category while for sensitive processes such as hot rolling, electroplating and finishing, MF/RO processes may be required (VU, 2008). There are many water reuse schemes regarding metallurgical industry around the world. For example, in Australia, the Port Kembla Steelworks which belongs to BlueScope Steel Company used $20 \mathrm{ML} / \mathrm{d}$ of recycled water from the Wollongong STP, saving 130 ML of freshwater each year (BlueScope Steel, 2006). The recycled water was under $\mathrm{MF/RO}$ treatment and used in a wide range of processes including cooling metal, cooling tower makeup, process water for cleaning and rinsing strip, steam generation for heating purposes, dust suppression and washing. Till 2006, the recycled 
water quality in Port Kembla Steelworks was superior to required quality in Sydney (Table 6). Besides, BlueScope Steel has also conducted interdepartmental water reuse schemes (wastewater from one sector is reused in another sector) and installed a $300 \mathrm{KL} / \mathrm{d}$ onsite treatment plant to provide secondary treated water for internal quench basins. The project was planned to be expanded to $35 \mathrm{ML} / \mathrm{d}$ and possibly $50 \mathrm{ML} / \mathrm{d}$ (Herd, 2006). Similar to Port Kembla Steelworks, Port Kembla Coal Terminal also receives recycled water from the Wollongong STP and has been using it for dust suppression since 2009 , reducing $70 \%$ fresh water consumption. Moreover, a new technology using filtration, de-ionisation and UV treatment to process wastewater from the electroplating has been introduced at Astor Metal Finishes Villawood factory in Sydney. It is a pioneering technology in Australia and is capable of recovering most of the wastewater (NSW Office of Water, 2010). Besides, the steel industry in China is also benefiting from recycled water use. The Taiyuan Steel Plant in system for treating a 50/50 combination of industrial and local sewage secondary effluent. Currently, the Taiyuan plant and Handan plant provides 50 and $48 \mathrm{ML} / \mathrm{d}$ of treated water for internal industrial process uses respectively (Zheng, 2010).

750

TABLE 6. Comparison between wastewater reuse quality of Kembla Steelworks and guidelines

\begin{tabular}{lll}
\hline Important parameters & Industrial water quality & $\begin{array}{l}\text { Required recycled water } \\
\text { quality in Sydney }\end{array}$ \\
\hline Chloride (mg/L) & 14.6 & 20 \\
Hardness & 9.5 & $<20$ \\
$\mathrm{pH}$ & $5.8-6.7$ & $6.5-8.5$ \\
Parasites (per 50 mL) & Non-detectable & $<1$ \\
Viruses (per 50 mL) & Non-detectable & $<2$ \\
Coliform (per 50 mL) & Non-detectable & $<5$ \\
\hline
\end{tabular}

Modified from Herd (2006). 

been often reported (Hrudey, 1981). However, it is more optimal and effective to reuse these effluents within the same industry (Casani et al., 2005). As early as 1980s, Gallop (1984) studied the chiller water reuse in poultry processing plants using activated carbon treatment. The study only described the fact that chiller water reused as flume water or scalder water rather than recirculating chiller water itself. Hiddink et al., (1999) pointed out that a great potential for water recycling and reuse in food industry seemed possible to reduce the use of water by $20-50 \%$. Till now, most food processing industries have recycled partial wastewater effluents for non-food and plant cleaning, washing or cooling processes but seldom of them reused wastewater for food preparation and processing. Some of the currently acceptable direct reuses are initial washing of vegetables, fluming of unprepared products and scalding water of meat and poultry (Rajkowski et al., 1996). As the quality of the food product obtained through recycling or reusing treated water should be at least equal to that of the food different food processing categories. Case studies are also being implemented widely. and UV disinfection to treat both wastewater streams from the food manufacturing process and stormwater onsite and reuse them for non-product utility purposes, saving $355 \mathrm{ML}$ of water per year. Due to its excellent achievements, it won first prize at the 2010 Global Water Awards in the category of Industrial Water Project of the Year (GWA, 2010). In addition, Matsumura and Mierzwa (2008) reviewed water reuse for non-potable applications in poultry processing plant in Brazil. They found that pre-chiller effluent including continuous 
for other non-potable applications after UF. The water from gizzard machine was able to be reused in inedible viscera flume as cascade water without pre-treatment. Besides, wastewater from thawing process and filer wash process might also be reused after filtration. By adopting water reuse programs, water consumption was reportedly reduced by $21.9 \%$.

Furthermore, Blocher et al. (2002) conducted a one-year study on water reuse at a fruit juice production plant in Germany. The plant used MBR plus two-stage NF treatment system. In the MBR, high COD removal (>95\%) was achieved. After the two-stage NF filtration, the chemical and bacteriological parameters of the treated water met the limits of the German Drinking Water Act with a water recovery of $81 \%$. Therefore, the treated water can be reused for various purposes (e.g., boiler make-up water, cooling water, pasteurisation or bottle prewashing). Mavrov et al. (2001) also studied the water reuse from low-contaminated process water in the food industry in Germany. The treatment system included four stages: (a) pretreatment: belt filtration, two-stage cartridge filtration and UV pre-disinfection; (b) maintreatment: first stage NF with spiral wound modules; (c) post-treatment: second stage NF with spiral wound modules; and (d) UV disinfection. The analysis of treated vapour condensate in a milk processing company indicated that the water quality (conductivity $<40$ $\mu \mathrm{s} / \mathrm{cm}$ at $25^{\circ} \mathrm{C} ; \mathrm{Ca}^{2+}<0.4 \mathrm{mg} / \mathrm{L} ; \mathrm{COD}<10 \mathrm{mg} \mathrm{O} / \mathrm{L}$ etc.) fulfilled the requirements for boiler make-up water. Similarly, it was concluded that the treated chiller shower water (conductivity $<200 \mu \mathrm{s} / \mathrm{cm} ; \mathrm{Ca}^{2+}<1 \mathrm{mg} / \mathrm{L} ;$ TOC $<4 \mathrm{mg} / \mathrm{L}$ etc.) in a meat processing company can be reliably reused as warm cleaning water. After investigating the use of several NF and RO membranes in 10 French industrial dairy plants to produce water for reuse, Vourch et al. (2005) concluded that both the single RO and NF/RO treated waters are capable of reusing as cooling water in terms of total organic carbon (TOC) concentration and conductivity.

Moreover, Hafez et al. (2007) reported the reuse of treated water effluent of the EL-Nile Company for the food industry in Egypt. The wastewater samples were generated from fruit 
juice and milk products lines and processed by MF/UF/NF/RO system. The WWTP treated 1.2 ML/d of wastewater, in which only $0.9 \mathrm{ML} / \mathrm{d}$ of water was processed through RO that can be reused in high pressure boilers. The water resulted from NF $(0.3 \mathrm{ML} / \mathrm{d})$ can be reused in industrial processes and low pressure boilers. However, there are also many limitations and considerations in the implementation of water reuse in food industry. The reasons may be both the high water quality requirements and public objections. The city of Toowoomba in Queensland, Australia could be a good demonstration. As the critical water situation has occurred and level 5 water restrictions have been employed, the project was initially supposed to achieve a great freshwater saving. However, although the six star water quality has far exceeded the drinking water quality specified in Australia Drinking Water Guidelines (ADWG), strong public objections have lead to its failure (Hurlimann and Dolnicar, 2010; Toowoomba City Council, 2006). Additionally, although water recycling and reuse has been widely conducted in many industries for years, it still has a great potential to improve recycling rate in many processes and sectors. For example, in Coke making and Plate mill industries, water reuse rates only account for 0-30\% (Johnson, 2003). In addition, water reuse in food processing and pharmaceutical production industries are stagnant because of psychological issues. These situations are waiting to be improved in the future.

\section{Environmental and Recreational Uses}

\section{Historical And CURRent Status}

Many environmental uses of recycled water such as the creation of wetlands and stream augmentation have originated historically from the discharge of treated wastewater. With the upgrade of wastewater treatment systems, the second benefit of releasing high quality water for environmental enhancement and water body preservation also gained recognition. Comparatively, recreational uses (e.g., the creation of artificial fountains and lakes, etc.) are 
mostly pre-designed, well planned and deliberately implemented. Depending on the likelihood of human exposure to recycled water, recreational uses can be further categorized into unrestricted and restricted access areas (Asano et al., 2007). Unrestricted recreational use includes wading and swimming while restricted use consists of fishing, boating and other non-body contact activities (U.S. EPA, 2004). The main objective of recycled water for environmental uses is to protect the ecosystem and public health, while for recreational uses, human health concern is the primary issue. Water quality requirements for these applications vary with the type and location of the receiving water body, yet in general, secondary treatment and disinfection is required (Asano et al., 2007; U.S. EPA, 2004).

\section{APPLICATIONS}

Wetlands. Wetlands have many noteworthy functions, such as flood attenuation, wildlife and waterfowl habitat, aquifer recharge and water quality enhancement. Nonetheless, over the past 200 years, approximately $90 \%$ of the wetlands in New Zealand and $50 \%$ of that in the Fortunately, the importance of wetlands has been recognized gradually. Using recycled water can regulate and improve regional hydrologic cycle, which in turn, can be further purified by wetlands before discharging to receiving water body or permeating into groundwater aquifer. Nowadays, wetland projects are carried out extensively either by the protection of natural wetlands or the construction of artificial wetlands, which are proved to be feasible approaches to protect ambient wildlife and groundwater system (Buchberger and Shaw, 1995; Vymazal, 2009). Although wetland projects are not widely adopted across Australia, the state of

849 Queensland was a leading state in constructing wetlands for effluent treatment (Greenway, 2005). Nine experimental wetlands were constructed in north Queensland to further treat 

greatly improved after detention in wetland. The treated water can either be used for wildlife habitation or reused in other fields. Likewise, in the U.S., recycled water from Iron Bridge Plant was supplied to a wetland, breeding hundreds of aquatic animals and plants. After that, it was further discharged into St. Johns River in Orlando, Florida (U.S. EPA, 2004). In addition, House et al. (1999) confirmed the feasibility of constructing wetland to treat and recycle 4.5 ML/d of domestic effluent for toilet flushing in North Carolina. Besides, in Europe, wetlands have been studied for more than 30 years and more than 100 constructed wetlands were put in operation in Czech Republic (Vymazal, 2002).

TABLE 7. Three constructed wetlands in Queensland

\begin{tabular}{|c|c|c|c|c|}
\hline Name & Major function & $\begin{array}{l}\text { Influent quality } \\
(\mathrm{mg} / \mathrm{L})\end{array}$ & $\begin{array}{l}\text { Effluent } \\
\text { quality (mg/L) }\end{array}$ & $\begin{array}{l}\text { Effluent reuse } \\
\text { applications }\end{array}$ \\
\hline $\begin{array}{l}\text { Ingham } \\
\text { Wetland }\end{array}$ & $\begin{array}{l}\text { Additional } \\
\text { wastewater } \\
\text { treatment }\end{array}$ & $\begin{array}{l}\text { BOD }>28 \\
\text { Nitrogen }>20 \\
\text { Phosphorus }>8\end{array}$ & $\begin{array}{l}\text { BOD }<15 \\
\text { Nitrogen }<10 \\
\text { Phosphorus }<7\end{array}$ & $\begin{array}{l}\text { Sugar mill; } \\
\text { Scrubbing flue gases } \\
\text { in the sugar mill; } \\
\text { FarmLand irrigations }\end{array}$ \\
\hline $\begin{array}{l}\text { Blackall } \\
\text { Wetland }\end{array}$ & $\begin{array}{l}\text { Additional } \\
\text { wastewater } \\
\text { treatment }\end{array}$ & $\begin{array}{l}\text { BOD }>28 \\
\text { SS }>60 \\
\text { Phosphorus }>5\end{array}$ & $\begin{array}{l}\text { BOD }<15 \\
\text { SS }<20 \\
\text { Phosphorus }<5\end{array}$ & $\begin{array}{l}\text { Commercial tree-lots } \\
\text { irrigation; } \\
\text { Golf course, parks } \\
\text { and garden irrigation; } \\
\text { Wetland development }\end{array}$ \\
\hline $\begin{array}{l}\text { Townsville } \\
\text { Wetland }\end{array}$ & $\begin{array}{l}\text { Additional } \\
\text { wastewater } \\
\text { treatment; } \\
\text { Wildlife habitat }\end{array}$ & $\begin{array}{l}\text { BOD }>33 \\
\text { SS }>25 \\
\text { Nitrogen }>32 \\
\text { Phosphorus }>8\end{array}$ & $\begin{array}{l}\text { BOD }<10 \\
\text { SS }<15 \\
\text { Nitrogen }<8 \\
\text { Phosphorus }<7\end{array}$ & $\begin{array}{l}\text { Discharge into a } \\
\text { natural wetland }\end{array}$ \\
\hline
\end{tabular}

Modified from Greenway (2005).

Recreational uses. Recreational uses of recycled water also represent a large portion, especially in densely populated area and tour scenic spots. However, it is worthy to note that using recycled water for recreational uses has to consider about the aesthetic quality as well as chemical and biological quality of water. The important parameters such as the number of 
pathogens, the concentration of nutrients and colour, odour and temperature are required to be monitored frequently to ensure the protection of public health and amenity. Generally, Class A treatment with tertiary and pathogen reduction is required (EPA Victoria, 2003). Water reuse schemes for recreational purposes have been accepted around the world for many centuries.

For instance, in Australia, the annual flow rate at Rutherglen, Gisborne and Woodend in

Victoria was 372, 450 and 210 ML respectively and approximately 50\% of the effluents were reused for recreational purposes (ATSE, 2004). Another example is the Lake Weeroona, which is a popular recreational lake in the middle of Bendigo, Victoria. The lake was constructed over 100 years ago and received stormwater inflows from a wide catchment historically. Nevertheless, since the dry weather condition and severely contamination of catchment areas, the lake dropped to less than half its capacity some times. Therefore, the city approached to explore the option of utilising recycled water to top up the lake. It has become the first recycled water scheme on recreational lake in Victoria and class A recycled water was supplied to Lake Weeroona with a total of 50 ML during September and October 2008.

The outcome was proved to be positive and the recycled water did not result in a significant change of water quality in Lake Weeroona (Byrt and Kelliher, 2009). Furthermore, recycled water for artificial snow making is also common in Mt. Buller and Mt. Hotham areas in Victoria as well as for animal viewing parks in Taronga Zoo, Sydney (Asano et al., 2007). In China, water reuse for restricted recreational use is widely conducted in cities suffering from severe water shortage, such as Beijing, Tianjin, Qindao, Shijiazhuang, Hefei and Xi'an. In Beijing, around $300 \mathrm{ML} / \mathrm{d}$ of recycled water is used for supplementing recreational parks with a total area of 2.7 million square meters. While in Japan, the Osaka City supplied treated wastewater to the water channels of Osaka castle to preserve the water level and ensure the recreational functions, which has become a popular method of restoring 
water flow in Japanese cities around 1980s (Suzuki et al., 2002). Additionally, in the U.S., the first water reuse project for restricted recreational use is the Santee Recreational Lakes project in San Diego, California which was constructed in 1961 and refurnished in 1997. The Padre Dam WWTP supplied 4 ML/d of recycled water to supplement evaporation water loss of the 7 lakes in Santee Lakes Region to ensure the fishing, boating and view watching activities. It was reported that recycled water use in recreational impoundments has already been as high as $40.8 \mathrm{GL} / \mathrm{yr}$ in California (DWR, 2003). Besides applications such as fountains and aquariums, recycled water is also extensively applied for stream flow augmentation in the San Luis Obispo Creek in California and San Antonio River in Texas (Asano et al., 2007; U.S. EPA, 2004).

\section{Non-potable Urban Uses}

\section{Historical and CurRent Status of Water Reuse in Urban Settings}

Water reuse applications in non-potable urban areas are listed in Figure 1. Among them, air conditioning, fire protection, toilet flushing and commercial applications such as car washing and laundries are major end uses. Those applications are observed mostly in well-developed countries and regions, especially in highly urbanized areas occupied by offices and other commercial and public buildings (Asano et al., 2007). In Australia, due partially to severe drought in 2001-03, water reuse and recycling has been increased rapidly in urban settings and was incorporated as an aspect of the policies for urban water reform (Radcliffe, 2006). In Japan, the urban non-potable use of recycled water in Shinjuku District started in the 1980s, which became a typical demonstration nationwide (Maeda et al., 1996). In the U.S., urban reuse systems have been developed in Colorado and Florida since 1960s (Asano and Levine, 1996). In Europe, non-potable urban reuse represents a major use of recycled water, accounting for $37 \%$ in southern Europe and $51 \%$ in northern Europe. In Luxembourg, it even 
occupies 95\% (Bixio et al., 2006). Nowadays, numerous urban water reuse projects are implemented in developed countries. Many of them have greywater collection and treatment systems, including Australia, Japan, the U.S., the UK, France, Germany and Spain, etc. In addition, many urban water reuse applications are combined with small and decentralised water recycling systems or coupled with other ongoing reuse applications such as landscape irrigation. Thus, similar to landscape irrigation uses, greywater and municipal wastewater are predominant sources for urban uses. Generally, secondary treatment with filtration and disinfection is regarded as a minimum requirement in the U.S. while tertiary treatment is compulsory in Australia and Spain (Asano, 2001; Asano et al., 2007).

\section{APPLICATIONS}

Fire protection. There are generally two types of fire protection systems, one is outdoor system with fire hydrants and the other is indoor sprinkler system. Recycled water for outdoor fire hydrants has been practiced for years. For example, in the U.S., 75 and 50 fire hydrants were connected to recycled water in Altamonte Springs, Florida; and Livermore, California, respectively. Likewise, 308 hydrants were connected to over $460 \mathrm{~km}$ of recycled water distribution pipelines in St. Petersburg, Florida (Asano et al., 2007). However, recycled water is rarely used in indoor sprinkler systems except for special situations due to cost and higher health risk issues. A commercial building located in the city of Livermore, California was a special case where the existing potable distribution system failed to provide sufficient pressure to meet fire fighting need. As a WWTP was located nearby, the building used recycled water for fire protection. Nonetheless, this was the only case in Livermore, where no

940 additional recycled water sprinkler systems were added (Asano et al., 2007; Johnson and 941 Crook, 1998). The city of Cape Coral, Florida, has even decided not to include fire protection in its future recycled water distribution systems as it often requires high flow rate at a limited 
and irregular time period, which can limit operations and managements. In some places, such as San Francisco and St. Petersburg, fire protection was shared between potable and recycled water so that the recycled water was used as an additional source of water for fire flows more often (U.S. EPA, 2004). Despite difficulties, recycled water in fire protection will be promising if well designed and planned in the future.

Toilet and Urinal flushing. Using recycled water for toilet flushing has been widely practised in Australia, Hong Kong, Japan and Europe. As early as 1964, Japan has started its investigations in large-area wastewater reuse for toilet flushing while the first demonstration was installed in Fukuoka City in 1978 and introduced to Tokyo, Chiba and Kobe later. By 1996, approximately 2100 buildings have installed onsite water reuse systems for toilet flushing with the water volume of $324 \mathrm{ML} / \mathrm{d}$ in Tokyo, Fukuoka and other big cities (Suzuki et al., 2002). In 1994, the 330 bed jail facility was constructed in Marin County, California, the U.S., using recycled water for toilet and urinal flushing. By 2001, dual plumbing systems for toilet flushing have also been installed in other 8 buildings in Marin County (Kelly and Stevens, 2005). In 2000, the first major in-building recycling scheme in the UK has been implemented. The system was established at the Millennium Dome in Greenwich and supplied 0.5 ML/d of recycled water to flush all of the toilets and urinals on site (Smith et al., 2000). At the same time, Sydney Olympic Park also used recycled water systems for toilet flushing in the stadium and nearby Newington areas, consuming $100 \mathrm{ML}$ of recycled water over the Olympic Games' period (Cooney, 2001; SOPA, 2001). In 2005, Hong Kong has built its first water reuse project at Ngong Ping of Lantau Island, where tertiary effluent (3 ML/d) was produced for public toilet flushing and restricted irrigation (Jimenez and Asano, 2008). Currently, the Irvine Ranch Water District, California, the U.S. has even mandated the 
use of recycled water for toilet flushing in new high rise office buildings (Anderson, 2003a).

The same regulation has been specified in Tokyo and Fukuoka, Japan (Suzuki et al., 2002).

According to the water demand in a typical office building (Figure 6), toilet flushing represents over $60 \%$ of water consumption in commercial buildings (Hills et al., 2002; Shouler et al., 1998). Dolnicar and Schafer (2009) reported that about $90 \%$ of respondents in a survey expressed their willingness to use recycled water on this particular end use. With high public support, using recycled water for toilet flushing can substantially reduce the potable water demand. Nevertheless, the effluent quality required for toilet flushing is very stringent. Asano et al. (2007) pointed out that the treated water should satisfy Class A level. Lazarova et al. (2003) have compared 10 different water quality criteria in various countries, including Australia, the U.S. and Europe in terms of physical, chemical and microorganic aspects. Generally, recycled water for toilet flushing must be highly disinfected for health protection as well as odourless and colourless for aesthetic reasons. MF/UF and RO treatment processes are in widespread use to achieve the required water quality. In most cases, as many commercial buildings are distributed intensively, toilet flushing systems are designed as part of a mixed urban water reuse plan, where recycled water from a centralised recycled water distribution system should be separated from potable water supply by dual pipe systems (Figure 7). As many developed countries have separated greywater from blackwater in kitchen and hand washing basin, some of the schemes (e.g., the Millennium Dome in UK) have adopted greywater treatment and recycling systems in toilet flushing (Figure 8), where wastewater from toilet flushing and residue from greywater treatment system are discharged to wastewater collection system and sent back to WWTP. In other situations, greywater is also blended with rainwater or stormwater to provide water for toilet flushing (Asano et al., 2007). 


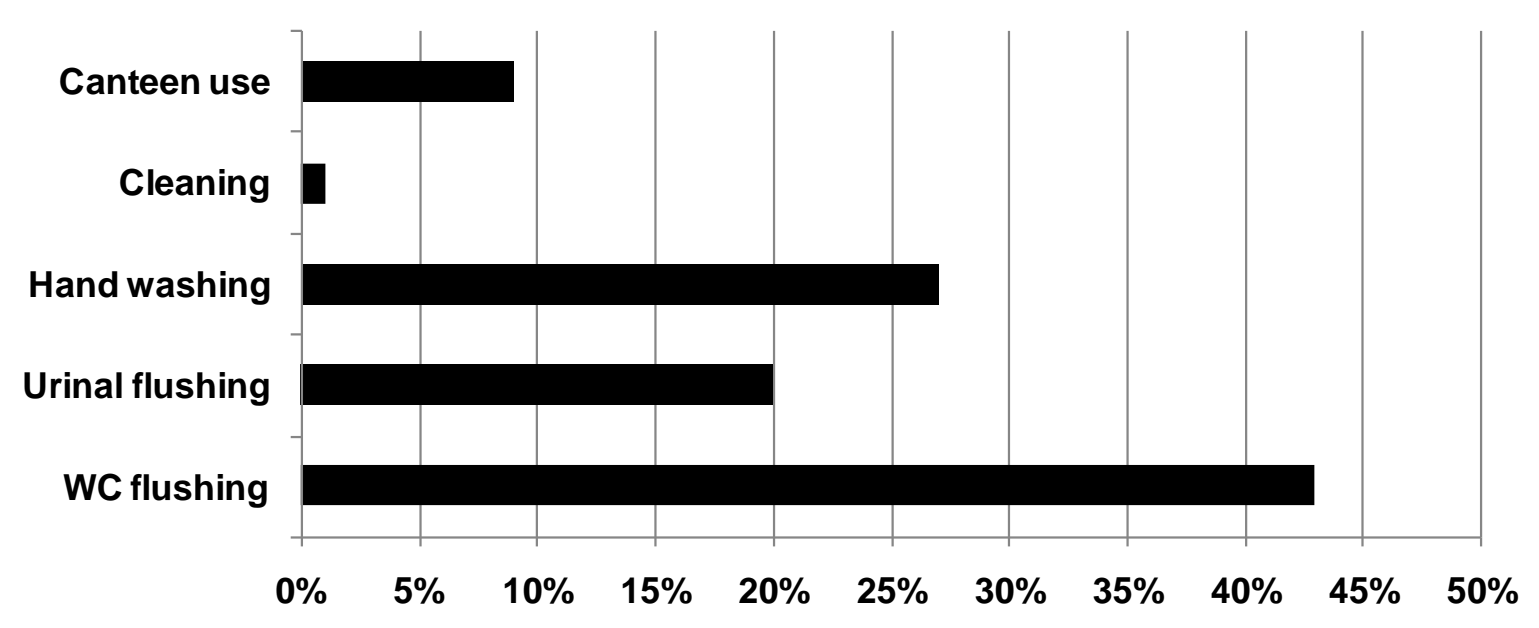

993 FIGURE 6. Water demand in a typical office building. Modified from Hills et al. (2002).

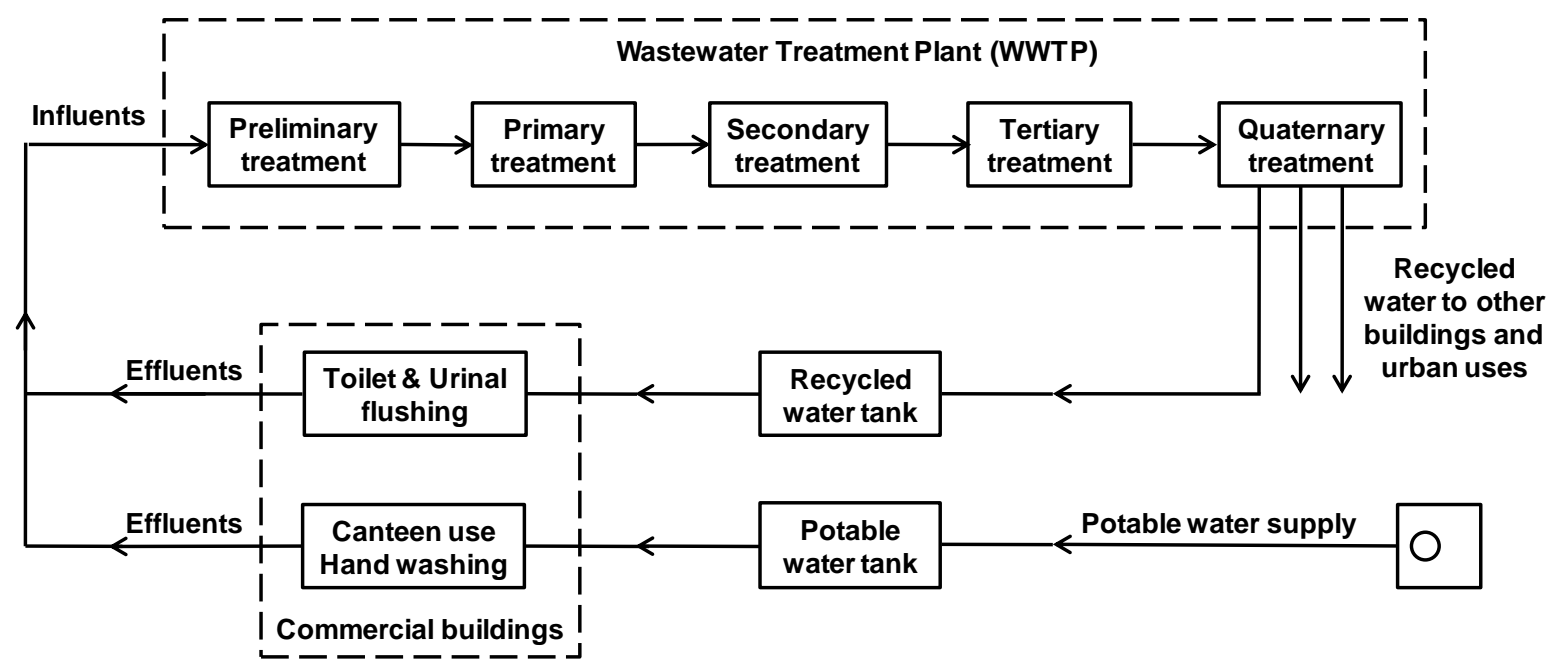

996 FIGURE 7. Simplified dual pipe system for toilet flushing in commercial buildings.

997 Modified from Asano et al. (2007). 


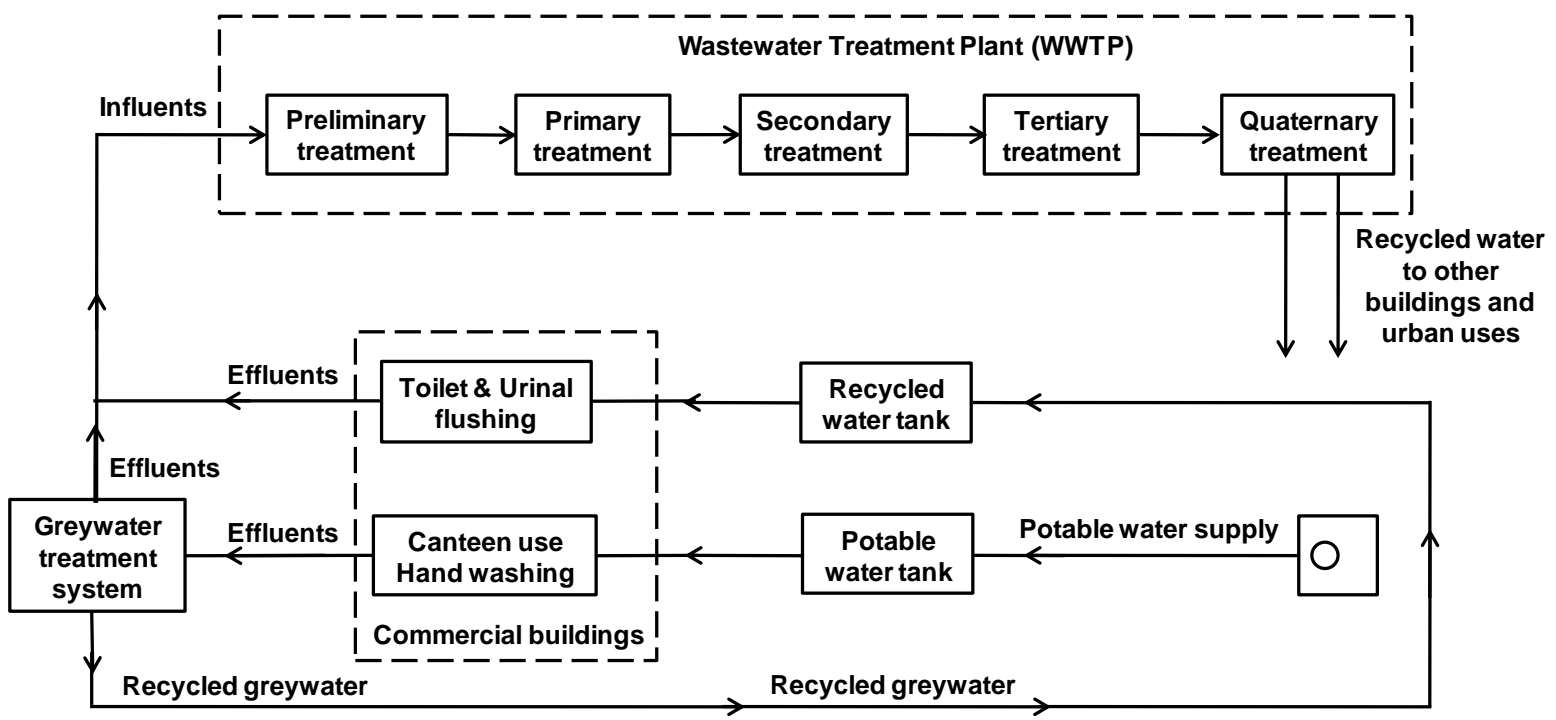

FIGURE 8. Simplified greywater treatment system for toilet flushing in commercial

buildings. Modified from Asano et al. (2007).

There are thousands of water reuse schemes implemented around the world on toilet

flushing. In Australia, one representative example is the Water Reclamation and Management

Scheme (WRAMS) owned by Sydney Olympic Park Authority. It has extended the urban

water recycling concepts to integrated water management by incorporating both stormwater and recycled water in recycled water delivery systems. The novel stormwater reservoir design enabled stormwater from the Olympic Park and excess secondary effluent from STP to be stored and regulated so that the subsequent Water Treatment Plant (WTP) can be operated at any rate to cope with large events. Up to $7 \mathrm{ML} / \mathrm{d}$ of recycled water under MF, UV and superchlorination was used for toilet flushing and open space area irrigation at sporting venues in Olympic Park, saving $850 \mathrm{ML} / \mathrm{yr}$ of Sydney's freshwater supply. The additional recycled water also served 2000 residential houses in Newington in terms of toilet flushing and garden watering. Recently, the end uses have been expanded to over 11, including swimming pool filter backwash and ornamental fountains (Chapman, 2006; Cooney, 2001). 
In Asia, the Beijing Capital International Airport wastewater reuse project in Beijing,

1017 China is a typical showcase. This project was started in 2007 and became the first airport

using UF/RO system in China. The membrane system (10 ML/d) supplies highly treated wastewater for toilet flushing in airport office buildings and the Airport Hotel. The excess treated water is also used in washing vehicles, irrigating plants, cleaning roads and providing cooling recirculation water. The project has been successfully implemented during the 2008 Beijing Olympic Games and currently serves approximately 20,000 visitors per day (DCC, 2008; Inge Watertechnologies, 2007). Water reuse projects in the Fukuoka City, Japan, are also good demonstrations. Since the city suffered severe droughts in 1978 and 1994, it started its researches and practices on indoor water reuse as a pioneer. The initial project was begun in 1980 when 12 public buildings were supplied with $0.4 \mathrm{ML} / \mathrm{d}$ of recycled water for toilet 1027 flushing. From that time on, the supply line was extended continuously and the service area was expanded from 316 ha to 770 ha in 1992 . The flow rate has been increased from 4.5 ML/d in 1995 to $8 \mathrm{ML} / \mathrm{d}$ at present (Asano et al., 1996).

Furthermore, Nolde (1999) investigated two greywater treatment systems for greywater 1031 reuse in toilet flushing in Berlin, Germany. The first system collected greywater from 1032 showers, bathtubs and hand-washing basins from 70 persons and treated it by four-stage Rotary Biological Contactor (RBC) while the other system collected greywater from shower and bathtub of a two-person household and treated it using a two-stage fluidized-bed reactor. The water analysis results showed that the recycled water satisfied the Berlin quality requirements and indicated that the total water for toilet flushing can be substituted with recycled water without a hygienic risk or comfort loss. March et al. (2004) also reported the greywater reuse for toilet flushing in a three-star aparthotel which has 81 rooms at Palma Beach in Spain. The wastewater came from bathtubs and hand washing basin was processed by filtration, sedimentation and disinfection using sodium hypochlorite. Under carefully 
controlled working conditions (disinfection at dose of $75 \mathrm{mg}$-chlorine L-1, storage time $<48 \mathrm{~h}$ and residual chlorine concentration $>1 \mathrm{mg} / \mathrm{L}$ in the cistern), satisfactory results were obtained. The wastewater treatment system was proved to be sustainable in terms of energy consumption, land requirements and waste production. More importantly, the system also had clear customer acceptance. Consequently, an average amount of $5.2 \mathrm{~m}^{3} / \mathrm{d}$ water was reused, which represents $23 \%$ of the total water consumption in the hotel. In addition, Friedler and Gilboa (2010) examined the microbial quality of treated RBC and MBR light greywater along a continuous pilot scale reuse system for toilet flushing in an eight storey high building in Israel. The microbial quality of UV-disinfected MBR and RBC effluents along the reuse system was not found to be significant different although hopping phenomenon was observed in MBR system. The quality of treated water was found to be equal or even better than clean water in toilet bowls flushed with potable water. Thus, the health risk associated with greywater reuse for toilet flushing was insignificant and the pilot-scale systems have been successfully operated for ten months.

1055

1056 water in air conditioning is mainly used for cooling purposes in high-rise commercial and residential buildings. In the U.S., examples include the 14-story Opus Centre Irvine II building in California and a sports stadium as well as commercial buildings in St Petersburg in Florida. Additionally, recycled water in commercial car washing and laundries is often used as part of a larger recycled water system since the water demand for these categories is relatively small. Commercial car washing using recycled water can be found widely, 
examples of commercial laundries using recycled water include Newington, Australia, and 1067 Marin County, California, etc. (Asano et al., 2007). Remarkably, large scale innovative wastewater recycling in commercial laundry do exists. Klingelmeyer, which is a medium 1069 sized laundry with 200 employees in Germany, is a good case. The laundry produced about $107010 \mathrm{ML} / \mathrm{d}$ wastewater and reused some part of it in a relatively small scale recycling unit from 10711999 (Buchheister et al., 2006). In 2004, a newly developed integrated process and an optimised washing system have been introduced and from 2006, the large scale unit with a

1073

1074

1075

1076

1077

1078

1079

1080

1081

1082

1083

1084

1085 0.2 ML/d MBR system has been put into operation. The pilot scale results showed that the recycled water quality fully met the quality requirement of the washing process thus several benefits were received accordingly (Hoinkis and Panten, 2008). Moreover, recycled water used in flushing of sanitary sewers and backwashing processes in WWTPs is also a common practice worldwide, accounting for $1-2 \%$ of urban water use. Besides, recycled water utilised for street cleaning was found in Australia and Brazil, while other applications such as snow melting was reported in some northern regions in Japan (Asano et al., 2007; IWA, 2010).

\section{Residential Uses}

As can be seen in Figure 1, residential uses of recycled water include toilet flushing, car washing, clothe washing, garden watering etc. Similar to non-potable urban uses, dual reticulation systems are required to supply recycled water to residential buildings or individual households. A simplified dual pipe system is exhibited in Figure 9. 


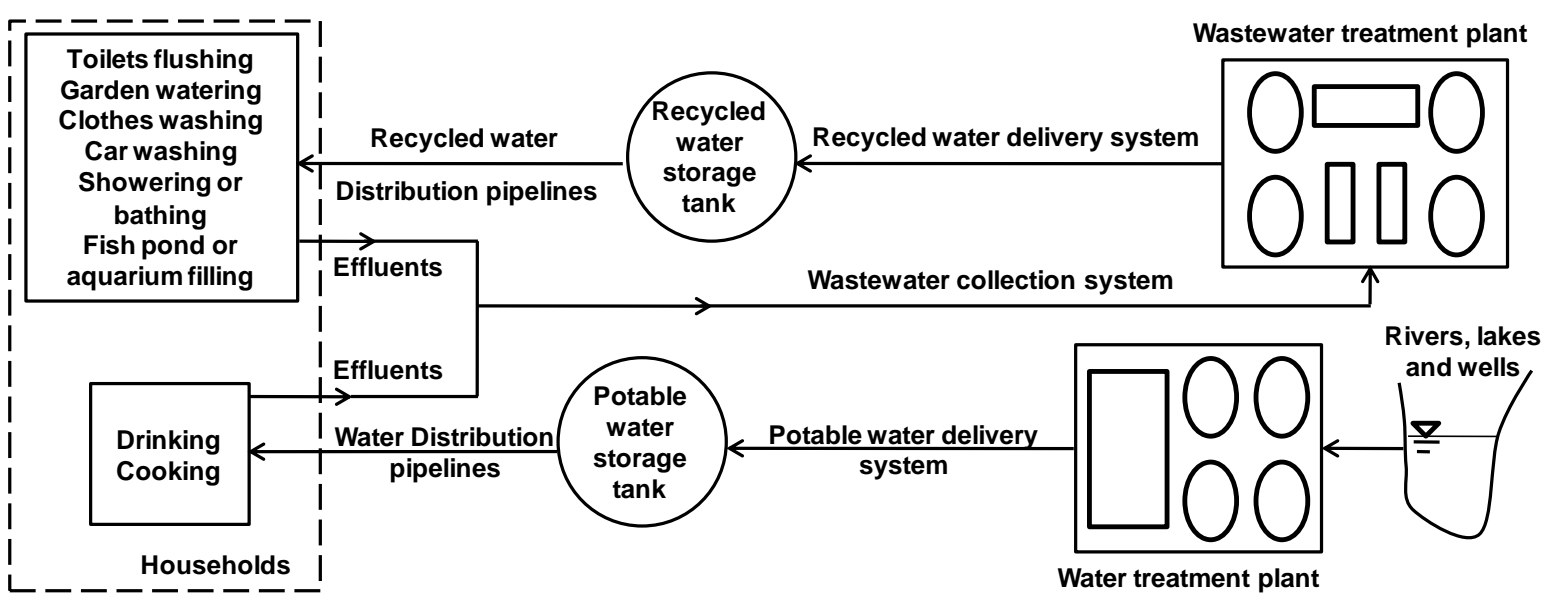

FIGURE 9. A simplified dual pipe system for residential uses.

\section{Historical and CurRent Status of Water Reuse in Residential Households}

As far as 1977, the St Petersburg dual distribution system in Florida, the U.S., started to serve about 8000 homes. The scheme has supplied more than $100 \mathrm{ML} / \mathrm{d}$ of recycled water to consumers since 1993 (ATSE, 2004; IWA, 2010). In 1993, a dual water supply system was commenced in Rouse Hill, Australia. However, several unacceptable cross connection errors were identified and rectified afterwards. In 2000, the Sydney Olympic Park scheme began to serve residential buildings at Homebush Bay with dual pipe systems as well. Currently, much more schemes on residential areas are conducted or under construction worldwide (ATSE, 2004; Wilson, 2008). However, the use of recycled water for residential homes and buildings can be more challenging compared with commercial offices and buildings, due to concerns about potential cross connections and accidental exposure, especially to children (Asano et al., 2007). Dolnicar and Schafer (2009) reported that the population's reservations about recycled water on household use were more firmly held than those towards desalinated water. As a result, many countries and states have specified very stringent wastewater treatment requirements regarding residential use and Class A water quality is generally required. In the city of Gold Coast, Queensland, Australia, Class $\mathrm{A}^{+}$recycled water was mandated for toilet flushing and garden watering (GCW, 2004). 


\section{APPLICATIONS}

Centralised wastewater systems. In Australia, the first and largest full-scale wastewater reuse scheme for residential uses was carried out at Rouse Hill in 2001 (Anderson, 2003a; ATSE, 2004). The recycled water (255 ML/yr) from Rouse Hill STP was used for toilet flushing and outdoor uses in 4,500 households during that period (Farmhand Foundation, 2004). The scheme is continue to be expanded and currently serves more than 25,000 homes with the consideration of additional end uses such as washing machine. A survey conducted by Sydney Water showed that over $70 \%$ of 2,000 customers favoured washing clothes by recycled water. The original treatment technology was MF which has subsequently been replaced by deep-bed filtration and UV. The quality of recycled water complies with the requirements in the New South Wales Guidelines thus can be safely reused. Besides, the charges from July 2003 at Rouse Hill are 28 c/KL for reuse water vs. 98 c/KL for potable water (ASTE, 2004; DTI, 2006; Khan, 2010; Law, 1996). The scheme is planning to serve 100,000 people in 35,000 houses at the first stage and will cater for more than 450,000 people in 160,000 residential properties over the next 25 years (Anderson, 2003a; Storey, 2009). Mawson Lakes (428 ML/yr) is another large scale water recycling scheme in residential properties in Adelaide, South Australia. The dual water supply system receives highly treated wastewater from Bolivar STP and stormwater harvested in Salisbury. The recycled water is processed by tertiary treatment, dissolved dir flotation and filtration and chlorination and its quality complies with the requirements of the South Australia Reclaimed Water Guidelines thus can be safely reused. A telephone survey conducted among 136 residents at Mawson Lakes in 2002 indicated that the public acceptance was $99 \%$ for lawn irrigation, $49 \%$ for clothes washing and $0.7 \%$ for drinking. The project now serves 4000 homes with 11,000 residents in the area and the end use is not only restricted to residential uses but also includes public park irrigation, wetland reserve, institutional and office commercial uses (DTI, 2006; 
SAW, 2010). Moreover, the charges from July 2007 at Mawson Lakes are $87 \mathrm{c} / \mathrm{KL}$ for reuse water compared with $50 \mathrm{c} / \mathrm{KL}$ for 1 st tier $(125 \mathrm{KL} / \mathrm{yr})$ and $\$ 1.16 / \mathrm{KL}$ for 2 nd tier potable water (Radcliffe, 2008; Wang, 2011). The system is going to be expanded and serve more people in the future. Similarly, other dual distribution schemes on residential properties can be found at Pimpama Coomera in Queensland, New Haven Village in South Australia and Epping North in Victoria, etc. (Lazarova et al., 2003; Willis et al., 2011).

Onsite wastewater treatment and recycling systems. Onsite recycling projects are operated worldwide as well which often treat wastewater effluents as well as partial rainwater or stormwater collected on the roof individually and then use for toilet flushing, clothes washing and garden watering internally. Most of them are located in rural or suburban areas where accesses to public wastewater treatment systems are lacking. In Australia, as far as 1998, Mobbs has developed a demonstration of onsite water recycling system on his small house in Chippendale, Sydney. All wastewater from the house was collected in an underground tank which contained 3 filter beds with the function of biological treatment, and then it was processed by UV radiation. The $100 \mathrm{KL} / \mathrm{yr}$ of effluent was used for toilet flushing, clothes washing and garden watering. Initially, the system did suffer 3 smelly breakdowns during its first year, but after being well managed, it functioned perfectly without any maintenance (ATSE, 2004; Malcolm, 1998). Mobbs has written a book named sustainable house which described their water recycling system in detail. Likewise, in 1997, a two unit family dwelling called Toronto Healthy House was built in Canada. The Healthy House had its own wastewater treatment and recycling system $(120 \mathrm{~L} / \mathrm{d})$ with 4 levels of treatment, including anaerobic, bio-filtration, sand and carbon filtration and UV disinfection processes and the water was usually recycled up to 5 times. Treated water was then used for toilet flushing, laundry, bathing and garden irrigation. This house also collected rainwater for 
drinking purposes and used solar energy for household electricity consumption. Thus, it became a representative demonstration of sustainable house in Canada (Paloheimo, 1996).

More recently, onsite wastewater treatment systems are using more advanced and reliable technologies such as UF, MBR, RO, or NF. These processes are often used in large buildings due to cost, space and construction issues. Friedler and Hadari (2006) found that the RBC-based biological system is economically feasible when the building size reaches seven storeys (28 flats) while MBR-based biological system becomes economically feasible only if the building size exceeds 40 storeys. In the U.S., the first large-scale onsite water recycling system was conducted at the Solaire residential building. The building was completed in 2003 which is a 293-unit located at New York City, serving 1,000 residents. The recycling system uses MBR and UV processes which are located in the basement and treats more than 95 $\mathrm{ML} / \mathrm{d}$ of wastewater. Of the total recycled water, $34 \mathrm{ML} / \mathrm{d}$ is used for toilet flushing throughout the building, $43.5 \mathrm{ML} / \mathrm{d}$ is used as makeup water for the building's cooling towers, and 22.7 ML/d are used for landscape irrigation (AWMG, 2008; Wilson, 2008). The treated water is of high quality with BOD $<2 \mathrm{mg} / \mathrm{L}$, TP $<2 \mathrm{mg} / \mathrm{L}$ and $\mathrm{TN}<3 \mathrm{mg} / \mathrm{L}$ (GEC, 2006). This system has reduced the freshwater consumption by $75 \%$, approximately 34.2 GL/yr of water and significantly decreased energy consumption by $35 \%$. Consequently, the Solaire project has received the 2008 Environmental Business Journal Achievement Awards and become a successful model of "green" building (Voorhees, 2009). The system will continue to be operated in the future.

Groundwater Recharges

Importance AND CuRrent Status of WAter Reuse in Groundwater Recharge

Groundwater is a precious and indispensable water resource which has become the principal resource in many cities around the world. In Asia, more than one billion people rely on 
groundwater for drinking. And in Europe, groundwater takes up approximately $65 \%$ of total water supply. In particular, in Berlin, Germany, approximately $70 \%$ of the water for domestic and industrial uses comes from groundwater. In the Middle East and Africa, many countries such as Saudi Arabia, United Arab Emirates Libya and Oman also depend heavily on groundwater (Jimenez and Asano, 2008; RCW, 2010). Nonetheless, over-extraction has triggered groundwater depletion and related environmental problems. It was estimated that in some regions of Mediterranean, 58\% of coastal aquifers suffer from saline ingress so that agricultural industries were severely affected (Durham et al., 2002). Furthermore, ground subsidence has been observed in some big cities such as Shanghai and the Mexico City, which can be a huge threat to constructions and buildings.

Groundwater recharge with recycled water can reduce the decline of groundwater levels, dilute, filtrate and store recycled water, partially prevent saltwater intrusion and mitigate subsidence (Asano and Cotruvo, 2004; Feo et al., 2007). Asano et al. (2007) listed other 10 advantages over surface storage of recycled water. Since the 1960s, groundwater recharge with recycled water has been practiced many times around the world for both non-potable reuse and indirect potable reuse applications. For example, in the U.S., it accounted for $15 \%$ and $16 \%$ of total recycled water use in California and Florida, respectively (ATSE, 2004; Blair and Turner, 2004). Currently, it has become the fourth largest application for water reuse either via surface spreading or direct aquifer injection with over 100 projects in the U.S. and countless schemes worldwide. When it comes to the groundwater recharge method, surface spreading is simple and widely applied which provides the benefit of additional treatment by soil while direct aquifer injection is particularly effective in creating hydraulic barrier in coastal aquifers. Nevertheless, more investigations and considerations of aquifer locations and properties are necessary (Asano, 2001; Asano and Cotruvo, 2004). Seepage trench method is also practiced in Glendale, Arizona, the U.S., however, biological clogging 
problem has been observed (Blair and Turner, 2004). Besides recharge method, the required wastewater quality for groundwater recharge also depends on intended reuses. For instance, in Australia, as the treated water withdrawn from confined aquifers was planned to be used 1209 for agricultural applications in Adelaide, South Australia, tertiary treatment and nutrient 1210 reduction in wastewater were required, which complied with Australian national recycling guidelines. In the U.S., the wastewater was processed by advanced tertiary treatment with RO processes before injecting directly to the confined aquifer in Orange County, California, as the recycled water was planned to reuse for IPR in nearest areas after 2-3 years' retention time (Mills et al., 1998). In addition, Israel used spreading basins for wastewater infiltration. As the treated effluent was often reused for agricultural irrigations after 50 days' retention in groundwater aquifer, only the secondary treatment was required (Blair and Turner, 2004; Guttman et al., 2002).

\section{SUCCESSFUL EXAMPLES}

In Australia, since groundwater is playing a significant role in Western Australia and $60 \%$ of drinking water is sourced from groundwater aquifers on the Perth Basin. Studies and practices regarding groundwater recharge by recycled water are numerous. In 2003, the state conducted a pilot study named Mosman Peninsula aquifer recharge scheme which was to inject $1.5 \mathrm{GL} / \mathrm{yr}$ of recycled water and further reuse it for non-potable applications. The feasibility study indicated that the scheme could play a vital role in water recycling in Swan Coastal Plain (Blair and Turner, 2004). Additionally, the Water Corporation in Western Australia and Commonwealth Scientific and Industrial Research Organization (CSIRO) undertook a \$3 million project named Managed Aquifer Recharge (MAR) from 2005 to 2008, including the investigation of the wastewater quality improvement after soil aquifer treatment (SAT) regarding to the Floreat research project and the Halls Head indirect reuse project. The 
water withdrawn from the aquifer can be used in agriculture, golf course, parks and open spaces as well (CSIRO, 2009).

Having looked at all groundwater recharge schemes implemented around the world, California, the U.S., is regarded as one of the most experienced areas with over 40 aquifer recharge projects and a history of more than 25 years. The Orange County Water District (OCWD) in California has already successfully conducted several groundwater recharge projects and commenced one of the largest Groundwater Replenishment (GWR) systems in the world in 2007. The GWR system is a water purification system which purifies highly treated sewer water that is processed through MF, RO, UV disinfection and hydrogen peroxide technologies. Half of the repurified water is injected into OCWD's seawater intrusion barrier wells along the Pacific coastline, the other half is provided to groundwater spreading basins in Anaheim. The project has 3 growth stages with the production rate of 265, 321 and $474 \mathrm{ML} / \mathrm{d}$ in 2008, 2010 and 2020 respectively. By 2020, the population is estimated to increase by 0.5 million and the water demand is projected to increase by 20 $40 \%$. The GWR will be capable of supplying approximately $22 \%$ of water needed at that time. Besides, the GWR has other distinct strengths, including the reduction of the amount of water released to the ocean, the cheapest production cost compared to seawater desalination and the decrease of mineral levels in OCWD's groundwater (Asano et al., 2007; Durham et al., 2002; OCWD, 2008). It also represents a more cost-effective and energy-efficient solution compared to importing water from northern California (Wild et al., 2010).

In Europe, Berlin, Germany has adopted bank filtration and subsequently pond infiltration since the 1870s which is regarded as the earliest groundwater recharge case in the world. The $160 \mathrm{GL} / \mathrm{yr}$ of wastewater is under tertiary treatment and discharged into an unconfined and alluvial aquifer and after about 1 year's retention, the water pumped from the aquifer is supplied to drinking water supplies, which now satisfies $20-70 \%$ of the city's total 
drinking water demand. In the Middle East, a groundwater recharge project for seawater intrusion barrier as well as groundwater replenishment for agricultural irrigations is presently implemented in Salalah, Oman, where $20 \mathrm{ML} / \mathrm{d}$ of tertiary treated effluent is discharged to a series of recharge wells to form a barrier against seawater intrusion (Jimenez and Asano, 2008). Moreover, the largest water recycling scheme in Israel was the Dan Region Project (270 ML/d) which served a population of about 1.3 million. The secondary wastewater effluent was recharged to groundwater by spreading basins and purified by SAT. With 20 years' operation, the recycled water after SAT in aquifer has proved to be suitable for a variety of non-potable uses such as unrestricted agricultural, industrial, commercial, residential and recreational uses (Kanarek and Michail, 1996; Asano and Bahri, 2011).

When refers to Africa, the Atlantis Groundwater Recharge scheme is a typical case in South Africa. The groundwater aquifers have been recharged by stormwater and secondary wastewater since 1979 in the town of Atlantis. In the scheme, domestic and industrial wastewater is collected and treated separately in different pond and is discharged into different portions of the aquifer. Currently, about $3 \mathrm{GL} / \mathrm{yr}$ of tertiary treated domestic wastewater is recharged for unconfined and sand aquifer and after 6 months' retention time, this water is transported to drinking water pipelines, contributing to $25-40 \%$ of drinking water supply. Meanwhile, about $1 \mathrm{GL} / \mathrm{yr}$ of lower quality industrial wastewater is infiltrated through coastal basins and used as saltwater barrier. In Morocco, the SAT is also used in Ben Sergao in the Agadir area, where $750 \mathrm{ML} / \mathrm{d}$ of treated effluent after screening, pre-treatment in an anaerobic pond and an oxidation pond is supplied to 5 infiltration basins. After groundwater recharge and wastewater retention, the water is pumped for irrigation of crops, grass, alfalfa, wheat and corn. It can be seen that groundwater recharge for IPR requires high level pre-treatment while for agricultural purposes, the requirement is relatively flexible. 
Nevertheless, care must be taken to prevent aquifer leakage problems when recharging less treated wastewater (Asano et al., 2007; Jimenez and Asano, 2008).

\section{Indirect Potable Reuses}

IPR has been developed largely as a result of freshwater scarcity and accelerated due to advances in treatment technology that enables the production of high quality recycled water at increasingly reasonable costs and reduced energy inputs (Rodriguez et al., 2009). It refers to the water after discharged from STP is diluted with natural surface water or groundwater body and be further used as drinking water resources (ATSE, 2004). However, unplanned or incidental use of wastewater for drinking purposes has taken place for a long time as cases are scattered in industrial countries anywhere (Rodriguez et al., 2009). For example, in South Africa, the Rietvlei Dam near Pretoria, received secondary effluent and used it as raw water supplies for potable water treatment plants at downstream (Leeuwen, 1996). This phenomenon was also observed at the upstream of River Thames which received treated sewage and supplied London with water downstream. Besides, other unplanned IPR examples were cities along the Hawkesbury River in Australia, Yangtze River in China, Mississippi River in the U.S. and Rhine River in Germany and the Netherlands (Asano, 2001). Since the wastewater effluent quality often do not undergo the same stringent treatment as planned IPR, unplanned wastewater injection can degrade the raw water quality in reservoirs or rivers and trigger health risks to residents. These cases should be banned or replaced by planned IPR in the next couple of years. This review focuses on planned IPR. It is reported that more than 15 planned IPR schemes are running worldwide, some of which has been functioning for more than 20 years. Till now, these schemes are successfully operated and neither environmental nor public health problems have been detected (Asano et al., 2007; Dominguez-Chicas and Scrimshaw, 2010). 
In Australia, there have been a number of IPR projects (e.g., the Toowoomba in

Queensland and the Quaker's Hill in Sydney) proposed during the last two decade, which have been faltered due to public misgiving. For instance, the Toowoomba project faltered due to $62 \%$ public opposition on referendum in July 2006 and left a very uncertain future to Toowoomba town. Nevertheless, owing to severe water shortage and unforeseen drought conditions, by 2007, major IPR schemes such as the Western Corridor Recycled Water Project (WCRWP) in South East Queensland (232 ML/day) and the three-year trial of the Leederville aquifer replenishment in Western Australia (25-35 GL/yr) have been partially developed but their full implementation is not yet to be realised (Khan, 2011). Particularly, the WCRWP has a capacity of producing $182 \mathrm{ML} / \mathrm{d}$ of recycled water for industrial and potable purposes including supplementation of Wivenhoe Dam and the residents will end up with IPR without an alternative, because recycled water will be transported into dams and become a partial resource of drinking water supply. The recycled water policy has already changed from continuous use of IPR to emergency use when dams fall below $40 \%$ capacity. Similarly, the city of Goulburn, New South Wales, is also seeking support for a project to supply its dam with recycled water as a local survey conducted in 2008 showed a $41 \%$ objection towards IPR. Currently, Goulburn is undertaking lengthy community consultation on all its available water management options. The city of Perth is planning to inject highly treated recycled water processed by $\mathrm{MF} / \mathrm{RO}$ and UV from the Beenyup WWTP into the Leederville aquifer which is a major drinking water source for the metropolitan area by 2015 . Nevertheless, researches still have to be carried out in the future in terms of public interest, impact policies and potential risks (DTI, 2006; Hurlimann and Dolnicar, 2010; Rodriguez et al., 2009).

Singapore is one of the leading countries in IPR application. Since its water supply was heavily relied on imported water from Malaysia, the Singapore Water Reclamation Study 
(NEWater Study) has paid much effort on feasibility study of using recycled water as a source of raw water for Singapore's needs. The NEWater Factory constructed its first advanced water treatment plant in 2000 with a capacity of $10 \mathrm{ML} / \mathrm{d}$, equipping with $\mathrm{MF}, \mathrm{RO}$ and UV facilities. After a 2-year study, the produced water was proved to be cleaner than Public Utilities Board (PUB) water (raw fresh water drawn from river sources and reservoir water) in terms of colour, organic substances and bacteria count thus it can be a consistent, reliable and safe supplement to the existing water supply (Kelly and Stevens, 2005). Till now, the NEWater has a total of five operational plants at Bedok, Kranji, Seletar, Ulu Pandan and Changi respectively, meeting $15 \%$ of Singapore's water demand. In addition, the Changi NEWater Plant which is the fifth NEWater plant commenced in 2010 has become one of the largest membrane-based water recycling facilities in the world and has been awarded the 2010 Global Water Awards in the category of Water Reuse Project of the Year (GWA, 2010). Most of NEWater produced water is used for non-potable applications such as for industrial purposes, at the same time, IPR is also being on trial. Fortunately, education campaigns and visiting tours since 2003 contribute to high public acceptance of planned IPRs. Normally, the NEWater is introduced to reservoirs and blended with raw water and then the mixed water is subject to conventional treatment. In 2003, about 13.5 ML/d of NEWater was transported into the raw water reservoir. Currently, about $6 \%$ of this is added to raw water reservoirs, contributing $1 \%$ of total potable water supply. By 2011 , it will have the capacity to meet $30 \%$ of Singapore's water needs and it will increase its IPR application to contribute $3.5 \%$ of potable water supply. Furthermore, the government will continue to expand its NEWater capacity to $284 \mathrm{ML} / \mathrm{d}$ by 2020 , accounting for $40 \%$ of total water supply at that time (Asano et al., 2007; DTI, 2006; Khan and Roser, 2007; PUB, 2008).

The U.S. is the earliest country in IPR studies with several IPR projects distributed in California, Washington DC, Colorado and Florida. For example, in California, both the 
Colorado and Sacramento River received discharged wastewater from their tributaries and became the water supply sources at downstream, including Los Angeles and San Diego (Asano et al., 2007). The following IPR schemes are related to these two regions. Apart from the Groundwater Replenishment system in OCWD aforementioned, Los Angeles County of California has also implemented an IPR scheme named Montebello Forebay Groundwater water, imported river water and local storm runoff for replenishment. The recycled water was treated to a secondary standard with chlorination before 1977 . While after 1977, the media filtration was added to enhance virus inactivation during disinfection (Khan and Roser, 2007). During the late 1980s and early 1990s, the city of San Diego has operated a $1.9 \mathrm{ML} / \mathrm{d}$ river water. From 1995, the region has actively considered IPR of advanced treated effluent. The recycled water was produced to tertiary level by chemical coagulation, media filtration, RO and carbon adsorption technologies and then be discharged to the San Vicente Reservoir at a scale greater than $76 \mathrm{ML} / \mathrm{d}$. After that, the blended water from the reservoir was treated prior to distribution to consumers (Khan and Roser, 2007; Olivieri et al., 1996). Since the late 1980s, more stringent requirements have been specified when conducting IPR schemes by recycled water. Membrane technologies such as MF and RO combined with UV disinfection gradually displaced granular media filters and chlorination. While the feasibility on wastewater treatment techniques had been widely achieved during 1990s, public resistances often hindered the implementation of projects. Examples include the East Valley Water Recycling Project in 1995 and the Tempa Water Resource Recovery Project in 1987. More recently, early and intensive outreach to the general public coupled with reliable treatment techniques and experiences from other pilot projects result in successful implementation of GWR system in 2003, West Basin in 1995 and the Scottsdale Water 
Campus in 1998 (Jansen et al., 2007). Additionally, other recycling schemes associated with IPR include the Montebello Forebay Groundwater Recharge Project in California, Upper Occoquan Sewage Authority Water Reclamation Plant at Fairfax County in Virginia, Clayton County Water Authority Land Application System and Wetlands in Georgia, Hueco Bolson Recharge Project in Texas and F. Wayne Hill Water Resource Centre at Lawrenceville in Georgia (Water Corporation, 2011).

In Europe, the Torreele IPR project, located in Wulpen, Belgium, has been implemented since 2002. The recycled water processed by MF/RO/UV is discharged to the unconfined StAndre dune aquifer with a minimum retention time of 40 days. The extracted groundwater is further treated with aeration and rapid sand filtration and UV treatment prior to distribution as drinking water. The full scale project produces $40-50 \%$ of the drinking water demand, serving more than 60,000 people (Rodriguez et al., 2009; Van Houtte and Verbauwhede, 2007). The Langford Recycling Scheme in Essex \& Suffolk, England, was the first water purification project of its kind in Europe and commenced operation in 1997. After going through tertiary treatment (MF and UV), the recycled water is discharged to river Chelmer for flow augmentation as well as drinking water supply. The mixed water from the river Chelmer is abstracted for Hanningfield reservoir refill where it is treated again before being put into drinking water distribution pipelines. The scheme is associated with a population of up to 100,000 (Water Corporation, 2011).

\section{Direct Potable Reuses}

DPR refers to the water after highly treated is conveyed directly from treatment plant to the water supply system or introduced into the raw water supply immediately upstream of a WTP (Asano et al., 2007; ATSE, 2004). DPR projects are often regarded as a last resort in many countries as it is the most difficult category among all water reuse applications with respect to 
public perceptions, health risk concerns, technological capabilities and cost considerations. DPR will be considered only if the current potable water supply in that area is under severe conditions and other potable water alternatives are not available or not easily to be conducted. So far, the advanced wastewater treatment technologies such as membrane filtration and disinfection are capable of producing high quality potable water which far exceeds current drinking water standards. In addition, DPR offers the opportunity to significantly reduce the transportation cost because the recycled water will be injected to potable supply system directly thus dual pipe systems are not necessary. Still, there are some difficulties regarding to its implementation. For example, current analytical techniques on many trace constituents in wastewater, especially on some artificial synthetics such as endocrine disrupting compounds and pharmaceutical active compounds are still not sensitive enough to detect or recognise their potential risks to human health. Besides, it is very hard to persuade publics to accept DPR, which might be a long time effort (Asano et al., 2007).

In the U.S., there was a DPR case historically in the city of Chanute, Kansas, where the treated wastewater was used as an emergency water resource. During the drought in 1956-57, the recycled water, after about 20 days' treatment comprising of primary treatment, secondary treatment using trickling filter, a stabilization pond and the WTP, was sent to the water distribution system. The water roughly met the prevailing public health standards but its physical properties including colour, odour and taste were unpleasant and some foaming problems were observed. In 1985, a DPR demonstration project was constructed in Denver, Colorado. After 2 years' extensive study, it was concluded that the properly treated secondary wastewater was safe to add into drinking water supply for public consumption (Condie et al., 1994; Khan and Roser, 2007). Nonetheless, 1998 NRC report has stated that DPR without storing it first in a reservoir was not a viable option for potable water supplies (NRC, 1998). More recently, the new wastewater reclamation project in Cloudcroft, New Mexico, 
represents the U.S.' first move in the direction of DPR. Although it is actually an IPR project that the treated wastewater is blended 50/50 with spring and well water and retained in a reservoir for a few weeks before going into the distribution system, it is far more direct than aquifer recharge programs and similar projects. By using MBR and disinfection technologies, 1434 the system can produce high quality and safe drinking water (Koch, 2008). The whole treatment processes is illustrated in Figure 10. This project was completed in 2007 and is now serving 750 residents and several hundred tourists with a capacity of $680 \mathrm{KL} / \mathrm{d}$. After putting into effect, it recycles $100 \%$ of wastewater produced in the village, roughly $80 \%$ for potable use and $20 \%$ for non-potable use. The key factor for the success of Cloudcroft project is the strong public support from residents as they realize the severe water shortage circumstance in the village and the importance of water to their tourist economy. This project can be a good example and inspiration for other cities to emulate its policy and design of sustainable water reuse (Wedick, 2007).

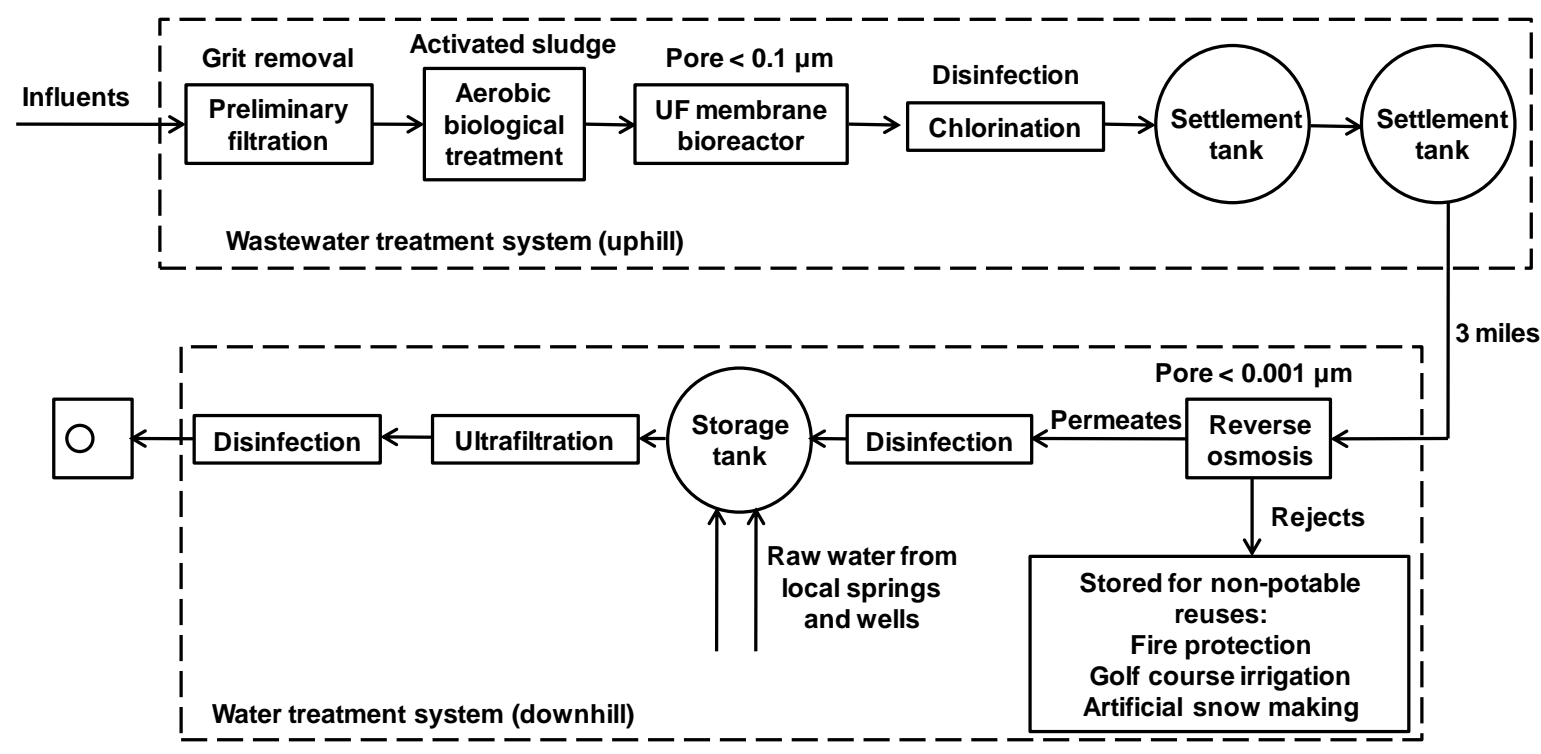

FIGURE 10. Wastewater treatment processes for the DPR project in Cloudcroft. Data adapted from Wedick (2007). 

serves approximately 250,000 people and has been applied for domestic supply for about 40 years (Dominguez-Chicas and Scrimshaw, 2010). Namibia is the most arid country in subSaharan Africa with more than $80 \%$ of the country covered by Namib Desert and Kalahari Desert. As a result of severe water shortages during droughts when the surface water was of poor quality and groundwater resources were also limited, Windhoek has constructed the world's first potable water treatment plant named Goreangab Water Reclamation Plant (WRT) in 1969 with an initial capacity of 4.3 ML/d, which treated blended water from the

Goreangab Dam as well as the Gammans WWTP. Effluent from Goreangab WRT was further mixed with water from other sources and reservoirs. Since the City had separated industrial effluent from domestic effluent, the origins of recycled water were domestic and business wastewater predominantly. The major treatment processes in Goreangab WRT are summarised in Table 8. The plant was upgraded several times and the last upgrade was undertaken in 1997 with the capacity up to $7.5 \mathrm{ML} / \mathrm{d}$. During the decades, recycled water contributed to 4 and $31 \%$ of the total supply in normal and drought periods. In 2002, a new Goreangab WRT was built next to the old plant with a capacity of $21 \mathrm{ML} / \mathrm{d}$. Compared with old treatment processes, the new plant used multiple barrier system and added more advanced techniques such as ozonation and membrane filtration. The new plant is now providing $35 \%$ of the daily potable water for the city (Du-Pisani, 2006; Wedick, 2007). In the absence of specific water quality guideline for DPR, Windhoek has compiled a specification for treated water based on Namibian, WHO, USEPA and EU guidelines. The specified value of turbidity, dissolved organic carbon, COD and total heavy metal in effluent are 0.1 NTU, 5 $\mathrm{mg} / \mathrm{L}, 20 \mathrm{mg} / \mathrm{L}$ and $20 \mu \mathrm{g} / \mathrm{L}$ respectively (Lahnsteiner and Lempert, 2007). To be more reliable, these parameters were monitored on a regular basis. Fortunately, the public in 
campaigns and extensive media coverage. To date, the DPR schemes runs successfully with no adverse effect being detected (Huertas and Salgot, 2008). It is said that in the near future,

1474 all excess recycled water will be used to recharge the Windhoek groundwater aquifers, 1475 consequently, the reliance on recycled water will be further expanded (Du-Pisani, 2006). 1476 Dolnicar and Schafer (2009) found that the recycled water is better than desalinated water in 1477 terms of infrastructure cost, treatment energy consumption and cost, green house gas 1478 emission and the aquatic environmental issues. In addition, if recycled water is going to inject 1479 into drinking water systems directly for DPR, dual pipe systems and recycled water storage 1480 tanks will be unnecessary, which can be a great saving as well. If it is possible to overcome 1481 technical and cost considerations as well as public objections, DPR will be a viable option for many severe water shortages countries and cities in Africa and the Middle East as some of them including Saudi Arabia and United Arab Emirates are using desalinated water as an 1484 alternative drinking water resource currently. 
TABLE 8. Comparison of treatment processes in old and new Goreangab WRT

\begin{tabular}{|c|c|c|c|}
\hline & Old Goreangab WRT & New Goreangab WRT & \\
\hline Influent & $\begin{array}{l}\text { Reservoir water } \\
\text { Secondary effluent } \\
\mathrm{Q}=4.3 \mathrm{ML} / \mathrm{d} \text { in } 1969 \\
\mathrm{Q}=7.5 \mathrm{ML} / \mathrm{d} \text { in } 1997\end{array}$ & $\begin{array}{l}\text { Reservoir water }(50 \%) \\
\text { Secondary effluent } \\
(50 \%) \\
Q=21 \mathrm{ML} / \mathrm{d} \\
\text { in } 2002\end{array}$ & $\begin{array}{l}\text { Secondary effluent } \\
(100 \%) \\
Q=24 \mathrm{ML} / \mathrm{d} \\
\text { in } 2007\end{array}$ \\
\hline Purification & $\begin{array}{l}\text { Coagulation and } \\
\text { flocculation } \\
\text { Dissolved air flotation } \\
\text { Rapid sand filtration } \\
\text { Granular activated carbon } \\
\text { filtration/ adsorption }\end{array}$ & \multicolumn{2}{|c|}{$\begin{array}{l}\text { Pre-ozonation } \\
\text { Coagulation and flocculation } \\
\text { Dissolved air flotation } \\
\text { Rapid sand filtration } \\
\text { Main ozonation } \\
\text { Biological and granular activated carbon } \\
\text { filtration/ adsorption } \\
\text { Ultrafiltration }\end{array}$} \\
\hline Disinfection & $\begin{array}{l}\text { Chlorination and } \\
\text { stabilisation }\end{array}$ & \multicolumn{2}{|c|}{ Chlorination and stabilisation } \\
\hline Effluent & Blending and Distribution & \multicolumn{2}{|l|}{ Blending and Distribution } \\
\hline
\end{tabular}

FUTURE TRENDS AND CHALLENGES OF WATER REUSE

Future Water Reuse Trends

Although the implementation or expansion of water reuse in a specific locale depends upon careful economic considerations, potential end uses of recycled water, public perceptions and the relative stringency of waste discharge requirements, the growing trend in water recycling and reuse is to consider water reuse practices as an essential component of sustainable and integrated water resources management (Asano and Bahri, 2011). More specifically, in the cities and regions of developed countries, where the use of freshwater resources is approaching the sustainable limit, recycled water will continue to be considered as an 1497 important alternative water resource, especially for non-potable uses. The possible water reuse trends in these severe water shortage areas are as follows:

- Large-scale water recycling schemes will be increasingly conducted in agricultural regions, industrial areas or sports fields, which can contribute to lower environmental 
impacts, greater amount of freshwater saving and higher efficiency in the use of existing resources. Particularly, industrial uses of recycled water are becoming more and more attractive, especially in oil and gas industry (Wild et al., 2010).

- Decentralized onsite and cluster wastewater treatment systems in commercial buildings and residential areas are gaining more attention, especially in rural and regional areas as decentralized approach is proved to be more flexible, reliable, simple and cost effective than centralized system (Massound et al., 2009; Suriyachan, et al., 2012).

- Urban non-potable and residential uses will also continue to increase and the number of urban reuse schemes (e.g., landscape irrigation, toilet flushing and car washing) will be as high or much higher than that of agricultural irrigation schemes (Brissaud, 2010).

- High value urban water reuse projects such as groundwater recharges schemes and IPR schemes will be a main stream, especially in countries like Singapore, the U.S. and $1513 \quad$ Europe.

- Tertiary or higher treatment is expected to be required in most recycled water end uses.

- New wastewater resources (e.g., agricultural return flows and concentrate from RO processes) and new end uses (e.g., washing machine, swimming pool, pet washing) will continue to be explored. wastewater, non-point source pollution and water reuse will be increasingly adopted. Through integrated approach, the use of recycled water may provide sufficient flexibility to allow a water agency to respond to short-term needs, as well as to increase the reliability of long-term water supplies (Angelakis and Durham, 2008; Asano and Bahri, 2011). Anderson (2003b) pointed out that there can be a potential to reduce the ecological footprint of water, sewage and drainage system by more than $25 \%$ when bringing together all water resources in management. 
- The integrated water resource management will be further incorporated into environment sustainable development and climate change adaptation (Asano and Bahri, 2011).

Additionally, in some regions of developed countries, due to abundant fresh water resources, small population and low intensity of land use, the key drivers of water reuse will be environmental pollution control and minimization rather than the provision of alternative water resource. Hence, the local authorities and water utilities will focus on the exploration and implementation of environmental-related end uses (e.g., irrigation, environmental flow augmentation, recreational impoundment, etc.). Other end uses that involve close contact with people (e.g., IPR) will not be widely discussed. With respect to less developed countries, over 2.6 billion people lack access to improved sanitation (Massound et al., 2009). UN (2007) estimates that there will be 292 cities in the world with more than 1 million people and more than $80 \%$ of population will live in developing countries by the year 2025 . Under strong population pressure and climate change, water reuse will be promising in developing countries:

- Agricultural irrigation will continue to be the predominant use of recycled water for many years in the future. Recycled water in agricultural activities will be intensified with additional sources of irrigation water and nutrients.

- Decentralized onsite and cluster wastewater treatment systems will be more favoured both in urban cities and small towns as centralized WWTPs are too costly to build and operate (Massound et al., 2009; Suriyachan, et al., 2012).

- DPR will be considered in some arid and semi-arid countries and regions (e.g., North Africa) where the DPR projects will be conducted more easily as some experiences from previous projects aforementioned are available.

- A large proportion of water reuse activities will involve secondary wastewater treatment only due to technical and economic constraints. However, when the cost of membrane 

treatment.

- Planned water reuse will be coupled with environmental sanitation management and be further incorporated into sustainable development.

Future Water Reuse Targets

1557

Although water reuse has been practiced in many countries around the world, the proportion of water reuse in total wastewater generation is still small. The global water reuse capacity is projected to rise from $33.7 \mathrm{GL} / \mathrm{d}$ in 2010 to $54.5 \mathrm{GL} / \mathrm{d}$ in 2015 and the largest growth market will exist in China, the U.S., Middle East, North Africa, Western Europe and South Asia (GWI, 2005). Many countries and regions have formulated their future water recycling plans and specified water reuse targets for the whole region based on their social, economic and environmental conditions (Table 9). To achieve these targets, their approaches or directions may vary greatly due to the viability and suitability of applications as a result of different water resource distributions, geographical locations, climate conditions, etc. For 1566 instance, in Australia, Adelaide has shown significant increase in its water recycling percentage since 2002 due to the implementation of the Water Reticulation Services Virginia scheme and the Willunga Basin Water Company scheme for irrigation purposes (Radcliffe, 2006). Likewise, Perth has boosted its water recycling rate through implementing several groundwater recharge schemes including the Mosman Peninsula aquifer recharge scheme and the MAR scheme (CSIRO, 2009). In Asia, the target for water reuse in China is set to be low because of the long-term demographic and social-economic status. Nevertheless, this situation is being improved as untreated wastewater reuse in agricultural irrigation is being and will continue to be replaced by treated wastewater and well planned irrigation schemes 
exists in higher value urban applications such as industrial process water and augmenting 1577 utility water supply, either through groundwater recharge or IPR schemes, such as the GWR 1578 in California (EgovAsia, 2009). In addition, in Europe, SAT will play an important role in a 1579 multi-barrier IPR in future water reuse direction with the implementation of innovative 1580 projects (Angelakis and Durham, 2008). Moreover, the Middle East already boasts some of 1581 the world's most innovative wastewater reuse facilities and some of the highest rates of water 1582 reuse. The recycling target will be achieved mostly through agricultural and landscape 1583 irrigation applications (WaterWorld, 2009). Furthermore, in Africa, countries are likely to 1584 increase the water reuse via irrigation, IPR and DPR applications. 
TABLE 9. Future water recycling and reuse targets in representative countries

\begin{tabular}{|c|c|c|c|}
\hline Country & City & Future targets & Reference \\
\hline \multirow{8}{*}{ Australia } & Sydney, NSW & $\begin{array}{l}35 \% \text { reduced water consumption by } 2011 \text {, increase wastewater recycling to } 70 \\
\text { GL/yr by } 2015 \text { and } 10 \% \text { by } 2020\end{array}$ & $\begin{array}{l}\text { NSW Office of Water, } \\
\text { 2010; Radcliffe, } 2006\end{array}$ \\
\hline & Canberra, ACT & Increase wastewater recycling from $5 \%$ to $20 \%$ by 2013 & ACT Health, 2007 \\
\hline & Melbourne, VIC & $\begin{array}{l}15 \% \text { reduced water consumption and } 20 \% \text { wastewater recycling by } 2010 \text { (this } \\
\text { target has been achieved two years ahead of schedule), achieve } 30 \% \text { substitution } \\
\text { of potable water with recycled water, treated storm water or rain water by } 2020\end{array}$ & $\begin{array}{l}\text { Radcliffe, 2006; The } \\
\text { Nationals, } 2007\end{array}$ \\
\hline & Brisbane, QLD & Increase wastewater recycling to $17 \%$ by 2010 & Radcliffe, 2006 \\
\hline & Gold Coast, QLD & Increase wastewater recycling from $20 \%$ currently to $80 \%$ by 2056 & Whiteoak et al., 2008 \\
\hline & Adelaide, SA & Increase wastewater recycling to $33 \%$ (30 GL/yr) by 2025 & Mekala et al., 2008 \\
\hline & Perth, WA & Increase wastewater recycling to $20 \%$ by 2012 & CSIRO, 2009 \\
\hline & Hobart, TAS & $10 \%$ reduction in water consumption & Radcliffe, 2006 \\
\hline China & $\begin{array}{l}\text { North China } \\
\text { South China }\end{array}$ & $\begin{array}{l}\text { Increase wastewater recycling from } 10 \% \text { currently to } 20 \% \text { by } 2015 \\
\text { Increase wastewater recycling from } 5 \% \text { currently to } 10 \% \text { by } 2015\end{array}$ & $\begin{array}{l}\text { Zhang et al., 2007; Zhang } \\
\text { and Zheng, } 2008\end{array}$ \\
\hline The U.S. & - & $\begin{array}{l}\text { Recycled water reuse on a volume basis is estimated to grow at } 15 \% \text { per year, } \\
\text { which will amount to } 37.86 \mathrm{GL} / \mathrm{d} \text { by } 2015 \text {. }\end{array}$ & Miller, 2006 \\
\hline \multirow{8}{*}{ Europe } & - & The estimated wastewater reuse potential is $2,455 \mathrm{GL} / \mathrm{yr}$ in 2025 & $\begin{array}{l}\text { Angelakis and Durham, } \\
2008\end{array}$ \\
\hline & Spain & Increase wastewater recycling from $368 \mathrm{GL} / \mathrm{yr}$ in 209 to $1,000 \mathrm{GL} / \mathrm{yr}$ by 2015 & WaterWorld, 2010 \\
\hline & Israel & The estimated wastewater reuse potential is $463 \mathrm{GL} / \mathrm{yr}$ in 2025 & \multirow{6}{*}{ Hochstrat et al., 2005} \\
\hline & Italy & The estimated wastewater reuse potential is $418 \mathrm{GL} / \mathrm{yr}$ in 2025 & \\
\hline & Germany & The estimated wastewater reuse potential is $126 \mathrm{GL} / \mathrm{yr}$ in 2025 & \\
\hline & France & The estimated wastewater reuse potential is $102 \mathrm{GL} / \mathrm{yr}$ in 2025 & \\
\hline & Bulgaria & The estimated wastewater reuse potential is $74 \mathrm{GL} / \mathrm{yr}$ in 2025 & \\
\hline & Portugal & The estimated wastewater reuse potential is $64 \mathrm{GL} / \mathrm{yr}$ in 2025 & \\
\hline \multirow{2}{*}{$\begin{array}{l}\text { The } \\
\text { Middle } \\
\text { East }\end{array}$} & $\begin{array}{l}\text { Abu Dhabi, United } \\
\text { Arab Emirates }\end{array}$ & $100 \%$ wastewater reuse by 2015 & WaterWorld, 2009 \\
\hline & Saudi Arabia & $\begin{array}{l}\text { Recycled water reuse on a volume basis is estimated to grow at } 30 \% \text { per year, } \\
\text { from } 260 \mathrm{GL} / \mathrm{d} \text { currently to } 2200 \mathrm{GL} / \mathrm{d} \text { by } 2016 .\end{array}$ & Al-Bawaba, 2010 \\
\hline Africa & Egypt & Increase wastewater reuse to $1.2 \mathrm{GL} / \mathrm{d}$ by 2017 & El-Atfy, 2007 \\
\hline
\end{tabular}


1586 Although water reuse is deemed to have a bright prospect in the future, some practical 1587 challenges, barriers and obstacles still exist and are waiting to be resolved:

1588 - A recent inquiry into the sustainability of non-metropolitan urban water utilities in New 1589 South Wales, Australia, indicated that 17 of the 106 utilities failed to comply with 1590 Australia's water quality standards (Armstrong and Gellatly, 2008). So far, there's no 1591 national regulation or standard of wastewater reuse in China and the U.S. Similarly, 1592 although France, Cyprus and Spain have published their water reuse guidelines, these 1593 regulations vary dramatically. Standards at European level do not exist either (Jimenez and Asano, 2008; Miller, 2006; Zhang et al., 2007). Furthermore, most Mediterranean countries including Greece, Libya, Morocco, Syria and Turkey have neither water reuse regulations nor guidelines. Lack of uniform water reuse criteria may lead to misunderstandings or misjudgements of current schemes. Therefore, guidelines on recycled water quality as well as policies that encourage communities to determine the most appropriate and cost-effective wastewater treatment solutions, based on local capacities and reuse options, should be developed (Asano and Bahri, 2011).

1601 very low concentrations. Consequently, the key point is to increase the ability to accurate measure trace contaminant levels that are associated with health risks in wastewater 
before and after treatment. Furthermore, additional research on wastewater treatment technologies can be the guarantees of safe and reliable reuse of wastewater (Miller, 2006). However, keeping up with technological advances in financially constrained countries is rather difficult to practise.

1611 

charging prices significantly lower than those in the major urban areas. Hence, without sufficient incentives and pricing reforms, water utilities, even the larger ones, will become unsustainable and water quality and security will suffer as a result (Armstrong and Gellatly, 2008).

- All stakeholders should be involved from the start in water reuse plans, and multistakeholder platforms should be created to facilitate dialogue, participatory technology development, innovation uptake and social learning. These actions will undoubtedly increase public recognition and acceptance on recycled water (Asano and Bahri, 2011; Bixio et al., 2006).

- Financial stability and sustainability should be ensured. Some reuse projects have not been constructed due to lack of funding or subsidies, especially in developing countries. At the same time, comprehensive accounting of financial, social and environmental costs and benefits on the projects has not been accomplished. These factors will inevitably hinder the implementation of water recycling and reuse in many fields. Therefore, government policies and additional investments by public and private sectors will be very important.

- Although the concept of integrated management of the water cycle has been proposed, only several countries have the real practice. To achieve integrated management, governmental sectors, environmental agencies and stakeholders should cooperate together. The various reuse options and sustainable management strategies should be considered from the outset in the design and plan. Nevertheless, it will still be a long term 
challenge to deal with the whole cycle of freshwater, wastewater and stormwater on the local scale due to financial, political and social considerations. In this case, learning continuously from best management practices and models around the world, such as Singapore and the Orange County, California, the U.S., can be quite useful (McCarthy, 2010). With more integrated water resource planning, reuse can then become an important part in sustainable development.

\section{CONCLUSIONS}

As a result of population increase, surface water quality deterioration, groundwater depletion and climate change, recycled water has already represented an important water supply in many countries. Due to different natural, social and economic conditions, the end uses vary markedly around the world. While agricultural irrigation still represents the largest current use of recycled water on a global scale, other end uses such as industrial uses and non-potable urban uses have made great progress in recent years, especially in Australia, Asia southern and western America, Europe, and the Mediterranean countries. Contemporarily, the potential for implementation of long term IPR or DPR exists in arid and semi-arid countries and regions, such as in the Middle East and African regions. Along with historical development, water quality criteria are becoming more stringent considering public health and acceptance issues. To achieve safer and more reliable water quality, new advanced treatment techniques such as MBR, NF, RO and UV disinfection are displacing activated sludge, granular media filters and chlorination gradually. Since successful water reuse projects on different end uses 
1673 including groundwater recharge, residential onsite recycling and landscape irrigation have 1674 been widely practiced and implemented, it is possible to learn from those experiences when 1675 planning and conducting new schemes in other places. To achieve higher efficiency, an 1676 integrated approach to plan and manage all available water resources as well as the end uses 1677 coherently and comprehensively on the local scale is being implemented and will be a future 1678 tendency in the following years. Publishing uniform wastewater reuse guidelines, building 1679 public confidence and getting financial and political support from government and 1680 organizations will contribute to integrated water resource management and sustainable 1681 development as a long term task. From an optimistic view, with focussed effort, wastewater 1682 can be well managed and reused in a sustainable way for more end uses and will benefit both 1683 the environment and mankind in a long term.

This work was supported by Australian Research Council (ARC) Industry Linkage Grant (LP100100494). 
ACT

CAS

CSIRO

DPR

EDCs

EPA

FC

GL

GL/d

GL/yr

GWR

HPM

IPR

IWMI

$\mathrm{KL} / \mathrm{d}$

MAR

MBR

MF

ML

ML/d

ML/yr

MVC
Australian Capital Territory

Conventional activated sludge

Commonwealth Scientific and Industrial Research Organization

Direct potable reuse

Endocrine disrupting compounds

Environmental Protection Agency

Faecal coliform

Gigalitre

Gigalitre per day

Gigalitre per year

Groundwater Replenishment

HOLMEN Paper Madrid

Indirect potable reuse

International Water Management Institute

Kilolitre per day

Managed Aquifer Recharge

Membrane bioreactor

Microfiltration

Megalitre

Megalitre per day

Megalitre per year

Mechanical vapour compression 
Nanofiltration

NSW

New South Wales

OCWD

Orange County Water District

$\mathrm{PhACs}$

Pharmaceutical active compounds

PUB

Public Utilities Board

QLD

Queensland

RBC

Rotary Biological Contactor

RO

Reverse Osmosis

SA

South Australia

SAT

Soil aquifer treatment

SS

Suspended solids

STP

Sewage Treatment Plant

TAS

Tasmania

TC

Total Coliforms

TDS

Total dissolved solids

TOC

Total organic carbon

TSS

Total Suspended Solids

UF

Ultrafiltration

UK

United Kingdom

US

United States

VIC

Victoria

WA

Western Australia

WRT

Water Reclamation Plant

WWTP

Wastewater treatment plant 
1693

1694

1695

1696

1697

1698

1699

1700

1701

1702

1703

1704

1705

1706

1707

1708

1709

1710

1711

1712

1713

1714

1715

1716

1717

1718

1719

1720

1721

1722

1723

1724

1725

1726

1727

1728

1729

1730

1731

1732

ABS (Australian Bureau of Statistics). 2010. Water Account Australia. Retrieved from http://www.ausstats.abs.gov.au/ausstats/subscriber.nsf/0/D2335EFFE939C9BCCA2577 E700158B1C/\$File/46100_2008-09.pdf

ACT Health (Australian Capital Territory Department of Health). 2007. Greywater use: guidelines for residential properties in Canberra. Retrieved from http://www.health.act.gov.au/

Ahluwalia, S. S. and Goyal, D. 2006. Microbial and plant derived biomass for removal of heavy metals from wastewater. Bioresource Technology, 98(12), 2243-2257.

Al-Bawaba. 2010. GE and Miahona to advance water reuse technology in Saudi Arabia. Retrieved from http://www.tradingmarkets.com/news/stock-alert/ge_ge-and-miahona-toadvance-water-reuse-technology-in-saudi-arabia-1205652.htmL

Al-Jayyousi, O. R. 2003. Greywater reuse: towards sustainable water management. Desalination, 156, 181-192.

Anderson, J. 2003a. The environmental benefits of water recycling and reuse. Water Science and Technology, 3, 1-10.

Anderson, J. 2003b. September. Walking like Dinosaurs: water, reuse and urban jungle footprints. Paper presented at Water Recycling Australia, AWA 2nd National Conference, Brisbane, Australia.

Angelakis, A. N. and Spyridakis, S. 1996. The status of water resources in Minoan times: a preliminary study. In: Angelakis, A. N. (ed.). Diachronic Climatic Impacts on Water Resources with Emphasis on Mediterranean Region. Heidelberg, Germany: SpringerVerlag, 161-191.

Angelakis, A. N., Bontoux, L. and Lazarova, V. 2003. Challenges and prospectives for water recycling and reuse in EU countries. Water Science and Technology, 3(4), 59-68.

Angelakis, A. N. and Durham, B. 2008. Water recycling and reuse in EUREAU countries: trends and challenges. Desalination, 218, 3-12.

Arlosoroff, S. 2006. Wastewater management, treatment, and reuse in Israel, in Wastewater Reuse-Risk Assessment. In: Zaidi, K. (Eds.), Decision-Making and Environmental Security. Springer, Dordrecht, Netherlands, pp. 55-64.

Asano, T. 2001. Water from wastewater-the dependable water resource. Stockholm Water Prize Laureate Lecture, Stockholm, Sweden.

Asano, T. and Levine, A. D. 1996. Wastewater reclamation, recycling and reuse: past, present and future. Water Science and Technology, 33(10-11), 1-14.

Asano, T. and Bahri, A. 2011. Global challenges to wastewater reclamation and reuse. On the Water Front, 2, 64-72.

Asano, T., Maeda, M. and Takaki, M. 1996. Wastewater reclamation and reuse in Japan: overview and implementation examples. Water Science and Technology, 34(11), 219226.

Asano, T. and Cotruvo, J.A. 2004. Groundwater recharge with reclaimed municipal wastewater: health and regulatory considerations. Water Research 38, 1941-1951. 
Asano, T., Burton, F. L., Leverenz, H. L., Tsuchihashi, R. and Tchobanoglous, G. 2007. Water reuse-issues, technologies and applications. New York, NY: McGraw Hill Book Company.

Asghar, M. N., Khan, S. and Mushtaq, S. 2008. Management of treated pulp and paper mill effluent to achieve zero discharge. Journal of Environmental Management, 88, 12851299.

ATSE (Australian Academy of Technological Sciences and Engineering). 2004. Water Recycling in Australia. Retrieved from http://www.atse.org.au/resource-centre/funcstartdown/136/

ASTM (American Society for Testing and Materials). 2010. Standard terminology used for microfiltration, ultrafiltration, nanofiltration and reverse osmosis membrane processes. D6161-10. Retrieved from www.astm.org/

AWMG (Applied Water Management Group). 2010. The Solaire wastewater treatment system. Retrieved from http://www.amwater.com/files/AMER0158_Project\%20 Sheets_Solaire-2.22.pdf

AWS (Alliance Water Solutions). 2010. Wastewater treatment systems. Water treatment. Retrieved from http://www.alliancewatersolutions.com.au/sections/index.php?sec= Water-Treatment

Bahri, A. 1999. Agricultural reuse of wastewater and global water management. Water Science and Technology, 40(4-5), 339-346.

Bahri, A. and Brissaud, F. 1996. Wastewater reuse in Tunisia: assessing a national policy. Water Science and Technology, 33(10-11), 87-94.

Barakat, M. A. 2010. New trends in removing heavy metals from industrial wastewater. Arabian Journal of Chemistry, 1878-5352.

Beekman, G. B. 1998. Water conservation, recycling and reuse. International Journal of Water Resources Development, 14, 353-364.

Bielefeldt, A. R. 2009. Water Treatment, Industrial. In: Schaechter, M. (Eds.), Encyclopedia of Microbiology, Third edition. Amsterdam, Netherlands: Elsevier/Academic, pp. 569586.

Bitton, G. 2011. Chapter 21: Wastewater reuse. In: Bitton, G. (eds.). Wastewater Microbiology, Fourth Edition, Hoboken, New Jersey: Wiley-Blackwell, pp. 599-618.

Bixio, D., Thoeye, C., Koning, J. D., Joksimovic, D., Savic, D., Wintgens, T. and Melin, T. 2006. Wastewater reuse in Europe. Desalination, 187, 89-101.

Blair, P. M. and Turner, N. 2004. Groundwater-a crucial element of water recycling in Perth, Western Australia. Water Sensitive Urban Design. Retrieved from http://newwaterways.org.au/userfiles/WC\%20Mosman\%20Pen\%20case_8INNh.pdf

Blocher, C., Noronha, M., Funfrocken, L., Dorda, J., Mavrov, V., Janke, H. D. and Chmiel, H. 2002. Recycling of spent process water in the food industry by an integrated process of biological treatment and membrane separation. Desalination, 144, 143-150.

Bluescope Steel. 2006. Community, Safety and Environment Report 2006. Retrieved from http://csereport2006.bluescopesteel.com/richmedia/BlueScope_Steel_CSE_Report_2006 .pdf

Brissaud, F. 2008. Criteria for water recycling and reuse in the Mediterranean countries. Desalination, 218, 24-33. 
Brissaud, F. 2010. Technologies for water regeneration and integrated management of water resources. In: Sabater, S. and Barceló, D. (eds.). Water Scarcity in the Mediterranean: Perspectives Under Global Change, Heidelberg, Berlin: Springer-Verlag.

Buchberger, S. G. and Shaw, G. B. 1995. An approach toward rational design of constructed wetlands for wastewater treatment. Ecological Engineering, 4, 249-275.

Buchheister, F., Hoinkis, J., Muth, S. and Panten, V. 2006. LIWATEC-laundry innovative waste water recycling technology. Desalination, 199, 76-77.

Byrt, C. and Kelliher, A. 2009. Use of recycled water in an urban recreational lake. Retrieved from http://www.rmcg.com.au/Publications_files/Recycled\%20Water\%20in\%20Urban \%20Lake.pdf

Calheiros, C. S. C., Rangel, A. O. S. S. and Castro, P. M. L. 2009. Treatment of industrial wastewater with two-stage constructed wetlands planted with Typha latifolia and Phragmites australis. Bioresource Technology, 100, 3025-3213.

Candela, L., Fabregat, S., Josa,A., Suriol, J., Vigues, N. and Mas, J. 2007. Assessment of soil and groundwater impacts by treated urban wastewater reuse. A case study: Application in a golf course (Girona, Spain). Science of the Total Environment, 374, 26-35.

Casani, S., Rouhany, M. and Knochel, S. 2005. A discussion paper on challenges and limitations to water reuse and hygiene in the food industry. Water Research, 39, 11341146.

Chapman, H. 2006. WRAMS, sustainable water recycling. Desalination, 188, 105-111.

Chiou, R. J., Chang, T. C. and Ouyang, C. F. 2007. Aspects of municipal wastewater reclamation and reuse for further water resource shortages in Taiwan. Water Science and Technology, 55(1-2), 397-405.

Condie, L. W., Lauer, W. C., Wolfe, G. W., Czeh, E. T. and Burns, J. M. 1994. Denver potable water reuse demonstration project: comprehensive chronic rat study. Food and Chemical Toxicology, 32(11), 1021-1030.

Cooney, E. 2001. Water reclamation plant a green winner for Olympic site. Paper presented at Australian Water Association, 19th Federal Convention, Canberra, Australia.

Crook, J. and Surampalli, R. Y. 1996. Water reclamation and reuse criteria in the U.S.. Water Science and Technology, 33(10-11), 451-462.

CSIRO (Commonwealth Scientific and Industrial Research Organization). 2009. Managed aquifer recharge. Retrieved from http://www.clw.csiro.au/mar/

DCC (Dow Chemical Company). 2008. Dow water solutions help to reuse wastewater in Beijing. Retrieved from http://www.syntao.com/PageDetail_E.asp?Page_ID= 6731

DCC (Dow Chemical Company). 2009. Dow membranes recycle cooling water blow-down water. Membrane Technology, 10, 4.

Das, N., Karthika, P., Vimala, R. and Vinodhini, V. 2008. Use of natural products as biosorbent of heavy metals-An overview. Natural Product Radiance, 7(2), 133-138.

DENR (Department of Environment and Natural Resources). 2010. Water reuse, Department of Water, Land \& Biodiversity Conservation, Fact sheet 2. Retrieved from http://www.environment.sa.gov.au/dwlbc/assets/files/fs0002_water_reuse.pdf

DERM (Department of Environment and Resource Management). 2009. Development approval for black water reuse trials-ERA 63. Environmental Protection Regulation. Retrieved from http://www.derm.Queensland.gov.au/register/p02975aa.pdf 
Diaper, C., Dixon, A., Butler, D., Fewkes, A., Parsons, S.A., Strathern, M., Stephenson, T. and Strutt, J. 2001. Small scale water recycling systems-risk assessment and modelling. Water Science and Technology, 43 (10): 83-90.

Dolnicar, S. and Saunders, C. 2006. Recycled water for consumer markets-a marketing research review and agenda. Desalination, 187, 203-214.

Dolnicar, S. and Schafer, A. I. 2009. Desalinated versus recycled water: public perceptions and profiles of the accepters. Journal of Environmental Management, 90, 888-900.

Dominguez-Chicas, A. and Scrimshaw, M. D. 2010. Hazard and risk assessment for indirect potable reuse schemes: An approach for reuse in developing Water Safety Plans. Water Research, July, 1-9.

DTI (Department of Trade and Industry). 2006. Water recycling and reuse in Singapore and Australia. Retrieved from http://www.bvsde.paho.org/bvsacd/cd65/water-recycling/ content.pdf

Du-Pisani, P. L. 2006. Direct Reclamation of potable water at Windhoek's Goreangab reclamation plant. Desalination, 188, 79-88.

Durham, B., Rinck-Pfeiffer, S. and Guendert, D. 2002. Integrated water resource management-through reuse and aquifer recharge. Desalination, 152, 333-338.

DWR (Department of Water Resources). 2003. Water Recycling 2030. Recommendations of California's recycled water task force. Retrieved from http://sustainca.org/files/ WRPuUSA-CA-DWR.pdf

EgovAisa. 2009. The future of water reuse. Retrieved from http://www.enterpriseinnovation. net/content/future-water-reuse

El-Atfy, H. 2007. Integrated National Water Resources Plan in Egypt. Retrieved from http://switch.cedare.int/cedare.int/files28\%5CFile2182.pdf

EPA Victoria. 2003. Guidelines for environmental management-Use of reclaimed water. Retrieved Sep 2010 from http://epanote2.epa.vic.gov.au/EPA/publications.nsf/ 2f1c2625731746aa4a256ce90001cbb5/64c2a15969d75e184a2569a00025de63/\$FILE/46 4.2.pdf

Eriksson, E., Auffarth, K., Henze, M. and Ledin, A. 2002. Characteristics of grey wastewater. Urban Water, 4, 85-104.

Evanylo, G. 2009. Water reuse: using reclaimed water for irrigation. Retrieved from http://pubs.ext.vt.edu/452/452-014/452-014.html

EWA (European Water Association). 2007. Water reuse in Europe. Retrieved from http://www.ewa online.de/journal/2007_07.pdf

Farmhand Foundation. 2004. Recycling our water. Retrieved from http://www.farmhand.org.au /downloads/62-73_Recycling_our_water_Part_6.pdf

FDEP (Florida Department of Environmental Protection). 2009. 2007 Reuse Inventory. Retrieved from http://www.dep.state.fl.us/water/reuse/news.htm

Feo, G. D., Galasso, M. and Belgiorno, V. 2007. Groundwater recharge in an endoreic basin with reclaimed municipal wastewater. Water Science and Technology, 55(1-2), 449457.

FRC (Florida Reuse Committee). 2003. Water reuse for Florida: Strategies for Effective Use of Reclaimed Water. Retrieved from http://www.dep.state.fl.us/water/reuse/docs/valued _resource_FinalReport.pdf 
Friedler, E. and Hadari, M. 2006. Economic feasibility of on-site greywater reuse in multistorey buildings. Desalination, 190, 221-234.

Friedler, E. and Gilboa, Y. 2010. Performance of UV disinfection and the microbial quality of greywater effluent along a reuse system for toilet flushing. Science of the Total Environment, 408, 2109-2117.

Galil, N. I. and Levinsky, Y. 2007. Sustainable reclamation and reuse of industrial wastewater including membrane bioreactor technologies: case studies. Desalination, 202, 411-417.

Gallop, R. A. 1984. The feasibility of recycling poultry chiller water after activated carbon treatment. Paper presented at Water Reuse Symposium III, San Diego, California.

GCW (Gold Coast Water). 2004. Water future, Recycled water use. Retrieved from http://www.goldcoast.Queensland.gov.au/attachment/goldcoastwater/Mtg7_RecycledMa ps.pdf

GEC (General Electric Company). 2006. Solaire Apartments, Battery Park. Water and Process Technologies, Case study. Retrieved from http://www.gewater.com/pdf/ Case\%20Studies_Cust/Americas/English/CS_BATT_COM_WW_1106_NA_GE_Logo. pdf

GreenTech. 2005. Signing Ceremony of Beijing Qinghe Water Reuse Plant Phase II. Retrieved from http://www.greentech.com.cn/newsshow_e.asp?type=1\&id=297

Greenway, M. 2005. The role of constructed wetlands in secondary effluent treatment and water reuse in subtropical and arid Australia. Ecological Engineering, 25, 501-509.

Guttman, Y., Sellinger, A., Bein, A. 2002. Simultaneous freshwater production and wastewater reclamation in a coastal aquifer at the Dan Plant, Israel. In: Dillon, P. J. (ed.). Management of Aquifer Recharge for Sustainability, Lisse, the Netherlands: Swets \& Zeitlinger, 321-326.

GWA (Global Water Awards). 2008. The best of the best in the International Water \& Desalination Industries. Retrieved from http://www.globalwaterawards.com/ supplements/2008.pdf

GWA (Global Water Awards). 2009. Retrieved from http://www.globalwater awards.com/ 2009.htmL

GWA (Global Water Awards). 2010. Retrieved from http://www.globalwater awards.com/

GWI (Global Water Intelligence). 2005. Reuse goes for global growth. Retrieved from http://www.globalwaterintel.com/archive/6/6/market-insight/reuse-goes-for-globalgrowth.html

Hafez, A., Khedr, M. and Gadallan, H. 2007. Wastewater treatment and water reuse of food processing industries. Part II: Techno-economic study of a membrane separation technique. Desalination, 214, 261-272.

Herd, W. 2006. Recycled water-case study: BlueScope Steel, Port Kembla Steelworks. Desalination, 188, 97-103.

Hiddink, J., Schenkel, A., Buitelaar, R. M. and Rekswinkel, E. 1999. Case study on closed water cycles in the food industry, Phase two. Institute for Inland Water Management and Waste Water Treatment. Report No. 99.001 (in Dutch).

Hills, S., Briks, R. and McKenzle, B. 2002. The Millennium Dome "Watercycle" experiment: to evaluate water efficiency and customer perception at a recycling scheme for 6 million 
visitors. Water Science and Technology, 46 (6-7), 233-240.

Hochstrat, R., Wintgens, T., Melin, T. and Jeffrey, P. 2005. Wastewater reclamation and reuse in Europe: a model-based potential estimation. Water Science and Technology, $5(1), 67-75$.

Hoinlis, J. and Panten, V. 2008. Wastewater recycling in laundries-from pilot to large-scale plant. Chemical Engineering and Processing, 47, 1159-1164.

Holtzhausen, L. 2002. More kudos for Durban water recycling plant. Water, Sewage and Effluent, 22, 32-35.

House, C. H., Bergmann, B. A., Stomp, A. M. and Frederick, D. J. 1999. Combining constructed wetlands and aquatic and soil filters for reclamation and reuse of water. Ecological Engineering, 12, 27-38.

Hrudey, S. E. 1981. Water reclamation and reuse. Journal of the Water Pollution Control Federation, 53(6), 751-767.

Huertas, E., Salgot, M., Hollender, J., Weber, S., Dott, W., Khan, S., Schafer, A., Messalem, R., Bis, B., Aharoni, A. and Chikurel, H. 2008. Key objectives for water reuse concepts. Desalination, 218, 120-131.

Hurlimann, A. and Dolnicar, S. 2010. When public opposition defeats alternative water projects-The case of Toowoomba Australia. Water Research, 44, 287-297.

Igwe, J. C., Ogunewe, D. N. and Abia, A. A. 2005. Competitive adsorption of Zn(II), Cd(II) and $\mathrm{Pb}(\mathrm{II})$ ions from aqueous and non-aqueous solution by maize cob and husk. African Journal of Biotechnology, 4(10), 1113-1116.

Inge Watertechnologies. 2007. Beijing capital international airport reuses wastewater with ultrafiltration technology from German inge AG. Retrieved from http://www.inge.ag/index_en.php

IWA (International Water Association). 2010. Reuse: urban, residential, commercial and municipal. Retrieved from http://iwawaterwiki.org/xwiki/bin/view/Articles/Urban\#H Commercialbuildings

IWMI (International Water Management Institute). 2006a. Insights from the Comprehensive Assessment of Water Management in Agriculture. Paper presented at Stockholm World Water Week, Colombo, Sri Lanka.

IWMI (International Water Management Institute). 2006b. Recycling realities: managing health risks to make wastewater an asset. Paper presented at Water Policy Briefing 17, Colombo, Sri Lanka.

IWMI (International Water Management Institute). 2010. Water irrigation and healthAssessing and mitigating risk in low-income countries. Retrieved from http://www.idrc.ca/openebooks/475-8/\#page_3

Jamwal, P. and Mittal, A. K. 2010. Reuse of treated sewage in Delhi city: Microbial evaluation of STPs and reuse options. Resources, Conservation and Recycling, 54, 211221.

Jansen, H. P., Stenstrom, M. K. and Koning, J. D. 2007. Development of indirect potable reuse in impacted areas of the United States. Water Science and Technology, 55(1-2), $357-366$.

Jern, N. W. 2006. Industrial Wastewater Treatment. London, U.K.: Imperial College Press. Jiang, Z. P. 2004. Water resource management and water quality issues in Beijing. Paper 

presented at International Conference on Science and Technology for Sustainability 2004, Tokyo, Japan.

Jimenez, B. and Asano, T. 2008. Water reuse: an international survey of current practice, issues and needs. London, U.K.: IWA publishing.

Johnson, R. 2003. Water use in industries of the future: steel industry. Retrieved from http://www.ana.gov.br/Destaque/d179-docs/PublicacoesEspecificas/Metalurgia/Steel_ water_use.pdf

Johnson, L. J. and Crook, J. 1998. Use of reclaimed water in buildings for fire suppression. Paper presented at Water Environment Federation 71st Annual Conference and Exposition, Orlando, Florida.

Kanarek, A. and Michail, M. 1996. Groundwater recharge with municipal effluent: Dan Region reclamation project, Israel. Water Science and Technology, 34(11), 227-233.

Karpiscak, M. M., Foster, K. E., and Schmidt, N. (1990). Residential water conservation: Casa Del Agua. Water Research, 26(6), 939-948.

Kelly, J. and Stevens, D. 2005. Recycled water tour 05, recycled water in Australia. Retrieved from http://www.recycledwater.com.au/uploads/File/documents/Final\%20 Report\%20Tour05LR.pdf

Keraita B., Drechsel P. and Amoah, P. 2003. Influence of urban wastewater on stream water quality and agriculture in and around Kumasi, Ghana. Environment and Urbanization, 15(2), 171-178.

Khan, S. J. 2010. Quantitative chemical exposure assessment for water recycling schemes. Retrieved from http://www.nwc.gov.au/resources/documents/Waterlines_Quantative_ Chemical_Exposure.pdf

Khan, S. J. and Roser, D. 2007. Risk assessment and health effects studies of indirect potable reuse schemes. Centre for Water and Waste Technology Report 2007/08. Retrieved from http://www.qwc.qld.gov.au/prw/pdf/prw-studies-indirect-potable-reuse.pdf

Koch, J. 2008. Pioneering water reuse. Water and Wastes Digest, January, 2008.

Koyuncu, I., Yalcin, F. and Ozturk, I. 1999. Colour removal of high strength paper and fermentation industry effluents with membrane technology. Water Science and Technology, 40(11-12), 241-248.

Kretschmer, N., Ribbe, L., and Gaese, H. 2004. Wastewater reuse for agriculture. Technology Resource Management \& Development-Scientific Contributions for Sustainable Development, 2. Retrieved from http://www.iwmi.cgiar.org/southasia/ruaf/CD/ Wastewater\%20Re-use\%20in\%20Agriculture\%20Kretschmer\%20et\%20al ..pdf

Lahnsteiner, J and Lempert, G. 2007. Water management in Windhoek, Namibia. Water Science and Technology, 55, 441-448.

Law, I. B. 1996. Rouse Hill-Australia's first full scale domestic non-potable reuse application. Water Science and Technology, 33 (10-11), 71-78.

Lazarova, V. and Bahri, A. 2004. Water reuse for irrigation: agriculture, landscapes and turf grass. Florida, U.S.A.: CRC Press.

Lazarova, V., Hills, S. and Birks, R. 2003. Using recycled water for non-potable, urban uses: a review with particular reference to toilet flushing. Water Science and Technology, 3(4), 69-77.

Leeuwen, J. V. 1996. Reclaimed water- an untapped resource. Desalination, 106, 233-240. 
Li, F. Y. 2009. Review of the technological approaches for grey water treatment and reuses. Science of the Total Environment, 407, 3439-3449.

Libralato, G., Annamaria, V. G., and Francesco, A. 2010. How toxic is toxic? A proposal for wastewater toxicity hazard assessment. Ecotoxicology and Environmental Safety, 73(7), $1602-1611$.

Liu, J. and Raven, P. H. 2010. China's Environmental Challenges and implementations for the world. Critical Reviews in Environmental Science and Technology, 40, 823-851.

Maeda, M., Nakada, K., Kawamoto, K. and Ikeda, M. 1996. Area-wide use of reclaimed water in Tokyo, Japan. Water Science and Technology, 33(10-11), 51-57.

Mekala, G. D., Davidson, B., Samad, M. and Boland, A. 2008. Wastewater reuse and recycling systems: A perspective into India and Australia. IWMI report. Retrieved from http://www.irrigationfutures.org.au/imagesDB/news/Mekala-Working-Paper-128.pdf

Malcolm, L. 1998. Why is it special? Australian Broadcasting Corporation. Retrieved from http://www.abc.net.au/science/planet/house/special.htm

Mann, J. G. and Liu, Y. A. 1999. Industrial Water Reuse and Wastewater Minimization. New York, NY: McGraw-Hill Book Company.

Manttari, M., Viitiko, K. and Nystrom, M. 2006. Nanofiltration of biologically treated effluents from the pulp and paper industry. Journal of Membrane Science, 272, 152160.

March, J. G., Gual, M. and Orozco, F. 2004. Experiences on greywater re-use for toilet flushing in a hotel (Mallorca Island, Spain). Desalination, 164, 241-247.

Massound, M. A., Tarhini, A. and Nasr, J. A. 2009. Decentralized approaches to wastewater treatment and management: Applicability in developing countries. Journal of Environmental Management, 90, 652-659.

Matsumura, E. M. and Mierzwa, J. C. 2008. Water conservation and reuse in poultry processing plant-A case study. Resources Conservation and Recycling, 52, 835-842.

Mavrov, V., Chmiel, H. and Belieres, E. 2001. Spent process water desalination and organic removal by membranes for water reuse in the food industry. Desalination, 138, 65-74.

McCann, B. 2010. North Las Vegas expands its water conservation activities. Water 21, August, 51-52.

McCarthy, D. 2010. Roundtable series examines challenges, benefits of water reuse. Retrieved from http://www.waterworld.com/index/display/article-display/5617485323/ articles/waterworld/wastewater/reuse-recyling/roundtable-series-examines-challengesbenefits-of-water-reuse.html.

Melin, T., Jefferson, B., Bixio, D., Thoeye, C., Wilde, W. D., Koning, J. D., Van der Graaf, J., and Wintgens, T. 2006. Membrane bioreactor technology for wastewater treatment and reuse. Desalination, 187(1-3), 271-282.

Metcalf and Eddy. 1999. Wastewater Engineering. Third Edition. New York, NY: McGrawHill Book Company.

Miller, G. W. 2006. Integrated concepts in water reuse: managing global water needs. Desalination, 187, 65-75.

Mills, W. R., Bradford, S. M., Rigby, M. and Wehner, M. P. 1998. Chapter 23: Groundwater Recharge at the Orange County Water District in Wastewater Reclamation and Reuse. In: Eckenfelder, W. W. Malina, J. F.and Patterson J. W. (eds.). Water Quality Management 
Library Volume 10, Washington, D.C.: CRC Press.

Mo, Z. H. and Chen, D. 2009. Introduction of process in Dagang Oilfield Reclaimed Water Plant. Water Technology, 3(3), 51-54.

Mohsen, M. S. and Jaber, J. O. 2002. Potential of industrial wastewater reuse. Desalination, $152,281-289$.

Morel, A., Diener, S., Alderlieste, M., Baumeyer, A., Bino, M. J., Burnat, J., Dallas, S., Hind, M., Martin, C., Priest, N. and Shrestha, R. R. 2006. Greywater management in low and middle income countries. Retrieved from http://www.eawag.ch/forschung/sandec/ publikationen/ewm/d1/Morel_Diener_Greywater_2006.pdf

Nolde, E. 1999. Greywater reuse systems for toilet flushing in multi-storey buildings-over ten years experience in Berlin. Urban Water, 1, 275-284.

NRC (National Research Council). 1998. Issues in potable reuse: the viability of augmenting drinking water supplies with reclaimed water. Washington, D.C.: National Academy Press.

NSW Office of Water. 2010. 2010 Metropolitan Water Plan. Retrieved from http://www.waterforlife. nsw.gov.au/mwp/2010_mwp

OCWD (Orange County Water District). 2008. Groundwater replenishment system. Retrieved from http://www.gwrsystem.com/about/overview.htmL

Okun, D. A. 1996. A history of nonpotable water reuse through dual distribution systems. Paper presented at Reclaimed water conference, North Carolina, USA.

Olivieri, A. W., Eisenberg, D. M., Cooper, R. C., Tchobanoglous, G. and Gagliardo, P. 1996. Recycled water-A source of potable water: city of San Diego health effects study. Water Science and Technology, 33(10-11), 285-296.

Ordonez, R., Hermosilla, D., San Pio, I. and Blanco, A. 2011. Evaluation of MF and UF as pretreatments piror to RO applied to reclaim municipal wastewater for freshwater substitution in a paper mill: A practical experience. Chemical Engineering Journal, 166, 88-98.

Oron, G., Gillerman, L., Bick, A., Gargir, M., Manor, Y., Buriakovsky, N., and Hagin, J. 2007. Advanced low quality waters treatment for unrestricted use purposes: imminent challenges. Desalination, 213(1-3), 189-198.

Paloheimo, R. 1996. Reusing treated wastewater in domestic housing: the Toronto Healthy House project. Retrieved from http://mha-net.org/msb/htmL/papers-n/palo01/ wastewa.htm

Pasqualino, J. C., Meneses, M. and Castells, F. 2010. Life cycle assessment of urban wastewater reclamation and reuse alternatives. Journal of Industrial Ecology, 15(1), 4963.

Pearce, G. K. 2008. UF/MF pre-treatment to RO in seawater and wastewater reuse applications: a comparison of energy costs. Desalination, 222, 66-73.

Persoone, G., Marsalek, B., Blinova, I., Torokne, A., Zarina, D., Manusadzianas, L., NaleczJawecki, G., Tofan, L., Stepanova, N., Tothova, L., and Kolar, B. 2003. A practical and user-friendly toxicity classification system with microbiotests for natural waters and wastewaters. Environmental Toxicology, 18(6), 395-402.

Pidou, M., Avery. L., Stephenson, T., Jeffery, P., Parsons, S. A., Liu, S. M., Memon, F. A. and Jefferson, B. 2008. Chemical solutions for greywater recycling. Chemosphere, 71, 
147-155.

PUB (Public Utilities Board). 2008. Singapore Government, Newater. Retrieved from http://www.pub.gov.sg/newater/Pages/default.aspx

Qadir, M., Wichelns, D., Raschid-Sally, L., McCornick, P. G., Drechsel, P., Bahri, A. and Minhas, P. S. 2010. Challenges of wastewater irrigation in developing countries. Agricultural Water Management, 97, 561-568.

Radcliffe, J.C. 2006. Future directions for water recycling in Australia. Desalination, 187, 77-87.

Radcliffe, J. C. 2008. Australian water recycling today-the big issues. Paper presented at National Water Recycling and Reuse 2008 Conference, Melbourne, Australia.

Rajkowski, K. T., Rice, E. W., Huynh, B. and Patsy, J. 1996. Growth of Salmonella spp. and Vibrio cholerae in reconditioned wastewater. Journal of Food Protection, 59(6), 577581.

RCW (Ramsar Convention on Wetlands). 2010. Groundwater replenishment. Wetland ecosystem services Factsheet 2 in a series of 10 . Retrieved from http://www.ramsar.org/pdf/info/services_02_e.pdf

Rodriguez, C., Buynder, P.V., Lugg, R., Blair, P., Devine, B., Cook, A. and Weinstein, P. 2009. Indirect potable reuse: a sustainable water supply alternative. International Journal of Environmental Research and Public Health, 6, 1174-1209.

Sagle, A. and Freeman, B. 2004. Fundamentals of Membranes for Water Treatment. In: The Future of Desalination in Texas. Volume 2, Report Number 363, Texas Water Development Board, Austin, TX, pp. 137-154.

Sala, L. and Millet, X. 2004. Chapter 12.2: Water reuse for Golf Course irrigation in Costa Brava, Spain. In: Lazarova, V. and Bahri, A. (eds.). Water reuse for irrigation: agriculture, landscapes and turf grass. Florida, FL: CRC Press.

SAW (South Australia Water). 2010. Mawson Lakes recycled water system. Government of South Australia. Retrieved from http://www.sawater.com.au/SAWater/WhatsNew/ MajorProjects/mawson_lakes. htm

Schmidt, E. 2008. Water recycling and reuse. Liquid Technology and Services, EET Corporation. Retrieved from http://www.eetcorp.com/corporate/lts-h20.pdf

Shanahan, M. 2010. Learning from others-recycled water use for irrigation. Recycled water future. Retrieved from http://lwa.gov.au/files/news/3751/youth-travel-fellowship.pdf

Shatanawi, M., Hamdy, A., and Smadi, H. 2007. Urban wastewater: problems, risks and its potential use for irrigation. Retrieved from http://ressources.ciheam.org/om/pdf/a66/ 00800229.pdf

Shouler, M., Griggs, J. and Hall, J. 1998. Water conservation. British Research Establishment Information Paper, November, 1998.

Sipma, J., Osuna, B., Collado, N., Monclus, H., Ferrero, G., Comas, J. and Rodriguez-Roda, I. 2010. Comparison of removal of pharmaceuticals in MBR and activated sludge systems. Desalination, 250, 653-659.

Smith, A., Khow, J., Hills, S. and Donn, A. 2000. Water reuse at the UK's Millennium Dome. Membrane Technology, 118, 5-8.

SOPA (Sydney Olympic Park Authority). 2001. Sydney Olympic Park Authority Act 2001 No 57. Retrieved from http://www.legislation.nsw.gov.au/fullhtmL/inforce/ 

act+57+2001+FIRST+0+N\#pt.4-div.3-sec.30

Sostar-Turk, S., Petrinic, I., and Simonic, M. 2005. Laundry wastewater treatment using coagulation and membrane filtration. Resource, Conservation and Recycling, 44(2), $185-196$.

State of California. 2003. California Codes-Water code section 13050, subdivision (n). Retrieved from http://www.leginfo.ca.gov/

Stevens, D. P., Smolenaars, S. and Kelly, J. 2008. Irrigation of amenity horticulture with recycled water. A handbook for parks, gardens, lawns, landscapes, playing fields, golf courses and other public open spaces. Retrieved from http://www.irrigation.org.au/assets/pages/6E9E6203-1708-51EB-A65470E3F41123EB/ Amenity\%20Hort\%20Arris\%20Recycled\%20Water\%20FINAL.pdf

Storey, M. V. 2009. Addressing aesthetic and technical issues associated with the use of recycled water in washing machines. Sydney Water. Retrieved from http://www.sydneywater.com.au/

Suriyachan, C., Nitivattananon, V. and Amin, A. T. M. N. 2012. Potential of decentralized wastewater management for urban development: Case of Bangkok. Habitat International, 36, 85-92.

SUW (Switch Urban Water). 2008. Switch demonstration project: Chongqing- greywater. Retrieved from http://www.switchurbanwater.eu/outputs/pdfs/CCHO_PUB_ Demonstration_New_campus_CQ.pdf

Suzuki, Y., Ogoshi, M., Yamagata, H., Ozaki, M. and Asano, T. 2002. Large-area and on-site water reuse in Japan. Retrieved from http://www.pwri.go.jp/eng/activity/pdf/reports/ Suzuki-yutaka020327.pdf

Szafnicki, K., Bourgois, J., Graillot, D., Benedetto, D. D., Breuil, P. and Poyet. J. P. 1997. Real-time supervision of individual wastewater treatment plants applied to the surface treatment industries. Water Research, 32(8), 2480-2490.

Tewari, P. K., Batra, V. S. and Balakrishnan, M. 2009. Efficient water use in industries: Cases from the Indian agro-based pulp and paper mills. Journal of Environmental Management, 90, 265-273.

The Nationals. 2007. Establishing a water substitution target-A new approach to securing Melbourne's water needs. Retrieved from http://www.vicnats.com/pdf/WaterDiscussion Paper.pdf

Tonkes, M., de Graaf, P. J. F., and Graansma, J. 1999. Assessment of complex industrial effluents in the Netherlands using a whole effluent toxicity (or WET) approach. Water Science and Technology, 39(10-11), 55-61.

Toowoomba City Council. 2006. Peter Beattie Insert to the Toowoomba Chronicle. Retrieved from http://www.toowoombawater.com.au/index.php?option $1 / 4$ com_docman\&task $1 / 4$ cat_ view\&gid $1 / 460 \&$ Itemid $^{1} / 423$

UN (United Nations). 1998. Appropriate technology for sewage pollution control in the wider Caribbean region. United Nations Caribbean Environment Programme. Kingston, Jamaica. Retrieved from http://www.cep.unep.org/publications-and-resources/technicalreports/tr40en.pdf

UN (United Nations). 2003. Wastewater treatment technologies: A general review. Economic and Social Commission for Western Asia. Retrieved from 
http://www.escwa.un.org/information /publications/edit/upload/sdpd-03-6.pdf

UN (United Nations). 2007. World population prospects, the 2006 revision. Retrieved from http://www.un.org/esa/population/publications/wpp2006/WPP2006_High lights_rev.pdf

UNEP (United Nations Environment Programme). 2008. Beijing 2008 Olympic Games, an environmental review: wastewater management. Retrieved from http://www.unep.org/publications/ebooks/ Beijing-report/Default.aspx?bid=ID0E1WCI USAID (United States Agency for International Development). 2009. Inside India, U.S. Congressional Delegation visits USAID Health Projects in Agra and Chennai. Retrieved from www.usaid.gov/in/newsroom/pdfs/ii_apr23_09.pdf

U.S. EPA (US Environmental Protection Agency). 2004. Guidelines for Water Reuse. Retrieved from http://www.epa.gov/ord/NRMRL/ pubs/625r04108/625r04108.pdf

Van Houtte, E. and Verbauwhede J. 2007. Torreele's water re-use facility enabled sustainable groundwater management in the Flemish dunes (Belgium). Paper presented at 6th IWA Specialist Conference on Wastewater Reclamation and Reuse for Sustainability, Antwerpen, Belgium.

Van Houtte, E., and Verbauwhede, J. 2008. Operational experience with indirect potable reuse at the Flemish Coast. Desalination, 218(1-3), 198-207.

VU (Victoria University). 2008. Guidance for the use of recycled water by industry. Retrieved from http://isi.vu.edu.au/sitebuilder/projects/knowledge/asset/files/31/ guidancefortheuseofrecycledwaterbyindustry.pdf

Voorhees, N. J. 2009. American water's Solaire project receives environmental awards. Business Wire, 9th of Jan, 2009. Retrieved from http://www.allbusiness.com/ environment-natural-resources/pollution-monitoring/11743882-1.htmL

Voorthuizen, E. V., Zwijnenburg, A., Meer, W. V. D and Temmink, H. 2008. Biological black water treatment combined with membrane separation. Water Research, 42, 43344340.

Vourch, M., Balannec, B., Chaufer, B. and Dorange, G. 2005. Nanofiltration and reverse osmosis of model process waters from the dairy industry to produce water for reuse. Desalination, 172, 245-256.

Vymazal, J. 2002. The use of sub-surface constructed wetlands for wastewater treatment in the Czech Republic: 10 years experience. Ecological Engineering, 18, 633-646.

Vymazal, J. 2009. The use constructed wetlands with horizontal sub-surface flow for various types of wastewater. Ecological Engineering, 35, 1-17.

Wang, X. J. 2011. Recycled and potable water consumptions at Mawson Lakes dual reticulation water supply system. Water, 38(4), 87-91.

Wang, J. L. and Chen, C. 2009. Biosorbents for heavy metals removal and their future. Biotechnology Advances, 27, 195-226.

Wang, L. K., Hung, Y. T., Lo, H. H., and Yapijakis, C. 2004. Handbook of industrial and hazardous waste treatment, Second Edition. Marcel Dekker, New York.

Wang, Z., Fan, Z., Xie, L. and Wang, S. 2006. Study of integrated membrane systems for the treatment of wastewater from cooling towers. Desalination, 191, 117-124.

Water Corporation. 2011. Water recycling- A global perspective. Retrieved from http://www.watercorporation.com.au/W/water_recycling_global.cfm\#Unplannedpotable re-use 
WaterWorld. 2009. Water reuse, desalination technology key to solving water scarcity challenges in Middle East. Retrieved from http://www.waterworld.com

WaterWorld. 2010. Water reuse market helps Spain secure future supply. Retrieved from http://www.waterworld.com

Wedick, M. 2007. Toward sustainable water systems: Potable reuse of wastewater. UP502Environmental Planning. Retrieved from http://www.melonwedick.com/ Water.pdf

Whiteoak, K., Boyle, R. and Wiedemann, N. 2008. National snapshot of current and planned water recycling and reuse rates. Retrieved from http://www.environment.gov.au/ water/publications/urban/pubs/national-recyclingsnapshot.pdf

Wilcut, E. and Rios, S. 2006. Water conservation and reuse in cooling water systems. Material Performance, 45(5), 38-40.

Wild, D., Buffle, M. O. and Cai, J. H. 2010. Water: a market of the future. Retrieved from http://www.sam-group.com/downloads/studies/waterstudy_e.pdf

Willis, R. S., Stewart, R. A., Williams, P. R., Hacker, C. H., Emmonds, S. C. and Capati, G. 2011. Residential potable and recycled water end uses in a dual reticulated supply system. Desalination, 272(1-3), 201-211.

Wilson, A. 2008. Towards wiser water strategies. Retrieved from http://continuingeducation.construction.com/article.php? $\mathrm{L}=5 \& \mathrm{C}=421 \& \mathrm{P}=1$

Winward, G. P., Avery, L. M., Frazer-Williams, R., Pidou, M., Jeffrey, P., Stephenson, T., and Jefferson, B. 2008. A study of the microbial quality of greywater and an evaluation of treatment technologies for reuse. Ecological Engineering, 32(2), 187-197.

World Bank. 2010. Improving wastewater use in agriculture: An emerging priority. Retrieved from http://siteresources.worldbank.org/INTWAT/Resources/ESWWastewaterAg.pdf

WSUP (Water \& Sanitation for the Urban Poor). 2010. Kumasi, Ghana. Retrieved from http://www.wsup.com/whatwedo/kumasi.htm

You, S. H., Tseng, D. H. and Guo, G. L. 2001. A case study on the wastewater reclamation and reuse in the semiconductor industry. Resources, conservation and recycling, 32, 7381.

Zhang, Y., Chen, X., Zheng, X., Zhao, J., Sun, Y., Zhang, X., Ju, Y., Shang, W. and Liao., F. 2007. Review of water reuse practices and development in China. Water Science and Technology, 55(1-2), 495-502.

Zhang, Y. and Zheng, X. C. 2008. The status and challenges of water infrastructure development in China. Paper presented at First Regional Workshop on Development of the Eco-efficient Water Infrastructure, Seoul, Korea.

Zheng, J. 2010. Industrial reuse role for membranes in China. Water 21, August, 54. 